\title{
SELEÇÃO DE GENÓTIPOS PARA PRODUÇÃO DE MANTEIGA DE CACAU NO VALE DO RIBEIRA, SÃO PAULO, BRASIL
}

\section{MARIA LUIZA SANT'ANNA TUCCI \\ Engenheiro Agrônomo}

Orientador: Prof. Dr. LUIZ CARLOS BASSO

Dissertação apresentada à Escola Superior de Agricultura "Luiz de Queiroz", da Universidade de São Paulo, para obtenção do título de Mestre em Ciências, Área de Concentração: Fisiologia e Bioquímica de Plantas.

\author{
PIRACICABA \\ Estado de São Paulo - Brasil \\ Maio - 1997
}




\section{SELEÇÃO DE GENÓTIPOS PARA PRODUÇÃO DE MANTEIGA DE CACAU NO VALE DO RIBEIRA, SÃO PAULO, BRASIL}

\section{MARIA LUIZA SANT'ANNA TUCCI}

Aprovada em: 27.06.97

Comissão Julgadora:

Prof. Dr. Luiz Carlos Basso

ESALQ/USP

Prof. ${ }^{a}$ Dr. ${ }^{a}$ Lireny Aparecida Guaraldo Gonçalves

FEA/UNICAMP

Prof. Dr. Luiz Antonio Gallo

ESALQ/USP

Prof. Dr. LUIZ CARLOS BASSO

Orientador 
Dedico à memória de Paulina Sant'Anna Tucci, minha mãe. 
Só é científico o que é refutável. Os que não se disponham a expor suas idéias à eventualidade da refutação, não participarão do jogo científico ( Popper, 1993). 


\section{AGRADECIMENTOS}

Ao Instituto Agronômico (IAC).

À CAPES.

À pesquisadora Marilene Leão Alves Bovi, chefe da Seção de Plantas Tropicais do Instituto Agronômico, por haver colocado seu saber e experiência, bem como a estrutura da unidade que dirige, à disposição deste trabalho, em todos os momentos. Meu agradecimento e carinho vão também para a bióloga Sandra Heiden Spiering e técnica de laboratório Nadir da Silva, funcionárias da Seção de Plantas Tropicais e para a engenheira agrônoma Stephânia M. Galvão Monteiro, bolsista.

Ao pesquisador Luiz Alberto Saes, chefe da Estação Experimental do Instituto Agronômico, localizada em Pariquera-Açu, de onde foram provenientes os frutos estudados e onde passei durante alguns meses, momentos transformadores, em companhia de cacaueiros, árvores seculares, aves selvagens, insetos, tempestades de verão e da dedicação exemplar do técnico agro-pecuário João Batista de Sales e do auxiliar José Roberto Ribeiro.

Ao Sr. Martin Aitken, diretor da empresa Almirante Centro de Estudos de Cacau, em Itajuípe (BA), em cujos laboratórios foram realizadas as análises de lipídios, bem como aos pesquisadores Antonio Figueira, gerente de pesquisas, que orientou o trabalho nessa fase e Smilja Lambert e aos técnicos de laboratório Cosme Silva Nascimento, Ruy Delmondes Cardoso e Ednailza Miranda Carvalho.

Da Comissão Executiva do Plano da Lavoura Cacaueira (CEPLAC), agradeço aos pesquisadores Adonias Virgens Filho, José Luiz Pires e Neide Alice Marques Pereira, bem como à bibliotecária Maria Neide da Silva.

Do Instituto de Tecnologia de Alimentos (ITAL), agradeço aos pesquisadores James Broadbent e Jane Menegaldo Turatti, bem como ao técnico de laboratório José Alvaro Ribeiro de Mattos. 
Ao pesquisador Paulo de Souza Gonçalves, Chefe do Programa de Seringueira do Instituto Agronômico, pela confiança, amizade e estímulo, durante todos estes anos.

Ao pesquisador Marco Antonio Teixeira Zullo, da Seção de Fitoquímica do Instituto Agronômico, por seus ensinamentos seguros e objetivos.

Da ESALQ, agradeço aos professores e pesquisadores Luiz Eduardo Gutierrez, a quem tive a satisfação de reencontrar e Luiz Carlos Basso, meu grande amigo, meu companheiro da turma ESALQ - 69, meu orientador.

A toda minha família, tão querida, tão presente e a todos os meus amigos, com uma referência especial à minha grande amiga Maria Sarah Iralah, em cuja opinião quem concebe e executa um projeto de pesquisa se transforma, modificando um pouco tudo ao seu redor. 
LISTA DE TABELAS

PAGINA

LISTA DE FIGURAS

RESUMO. V

SUMMARY

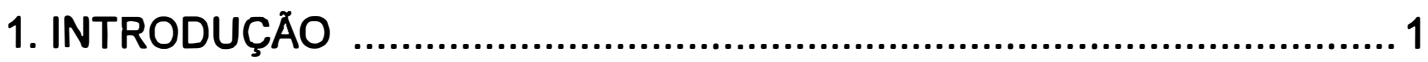

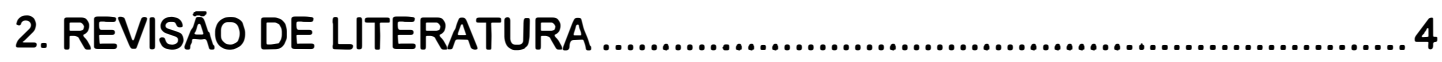

2.1. Origem e distribuição geográfica do cacaueiro ............................... 4

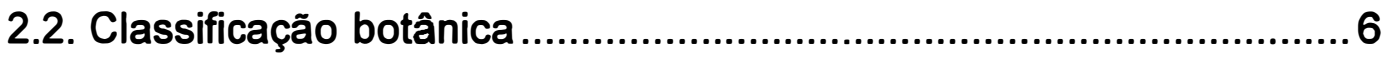

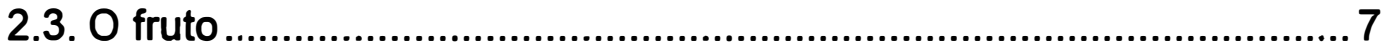

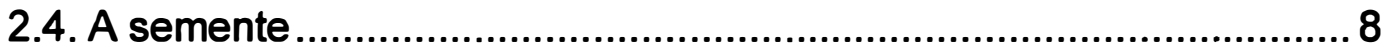

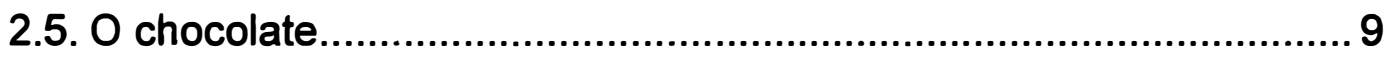

2.6. A manteiga de cacau ................................................................. 11

2.7. Teor de manteiga de cacau ........................................................ 15

2.8. Sintese da manteiga de cacau .................................................. 16

2.9. Influência das condições ambientais na qualidade da manteiga de

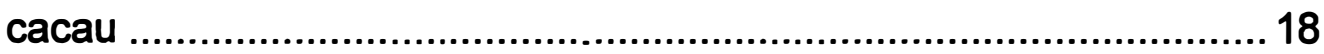

2.10. Gordura de outras espécies do gênero Theobroma.......................20

2.11. Polimorfismo da manteiga de cacau .......................................... 22

2.12. Substitutos da manteiga de cacau ................................................. 23

2.13. Outras gorduras associadas à manteiga de cacau......................... 25

2.14. Influência do processamento na qualidade da manteiga de cacau 26

2.15. Produção in vitro de lipídios da semente de cacau........................ 26

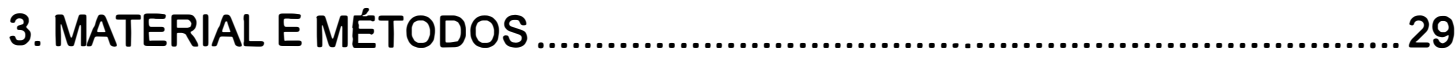

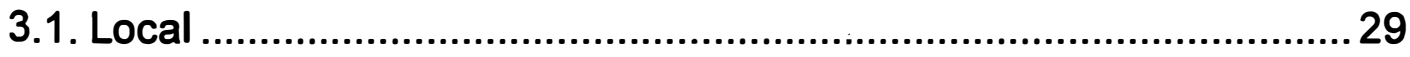

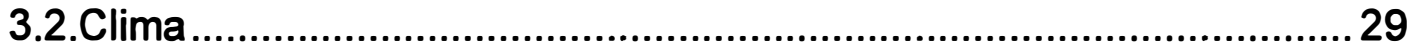

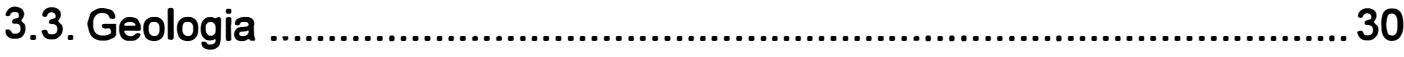

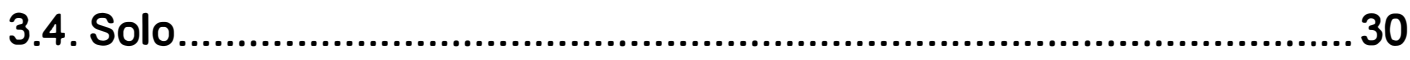

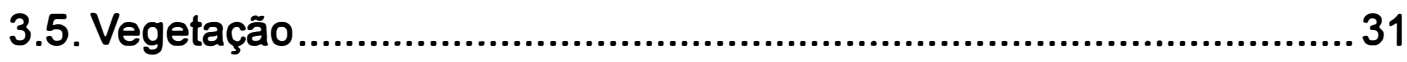




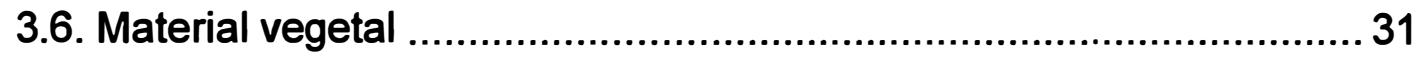

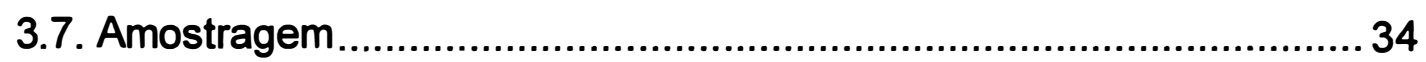

3.8. Caracterização de frutos e sementes ............................................. 35

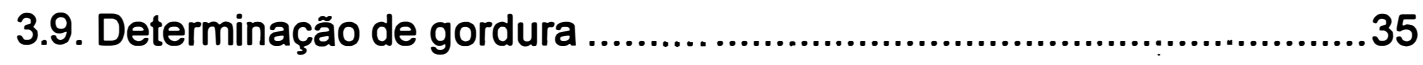

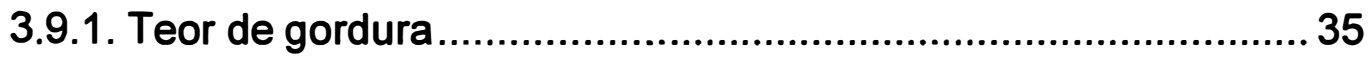

3.9.1.1. Determinação do teor de gordura pelo método do

Office International du Cacao et du Chocolat - OICC - (1963)........ 35

3.9.1.2. Determinação do teor de gordura pelo método de

Ressonância Nuclear Magnética (RNM) ..................................... 35

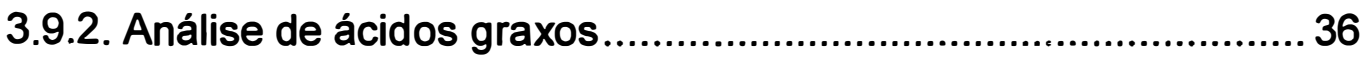

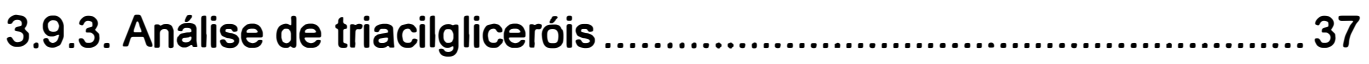

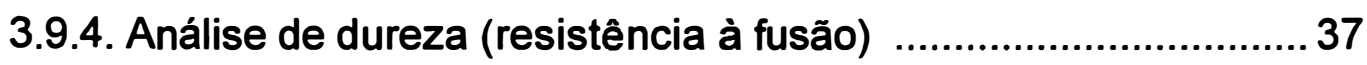

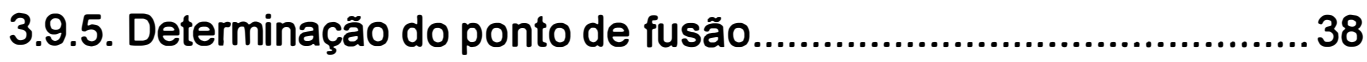

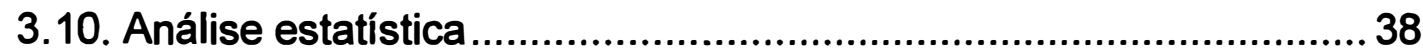

4. RESULTADOS E DISCUSSÃO............................................................ 40

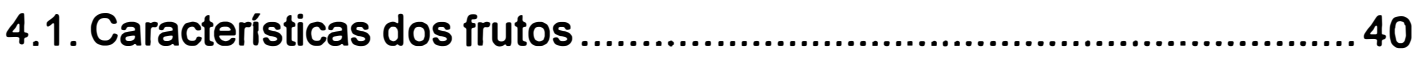

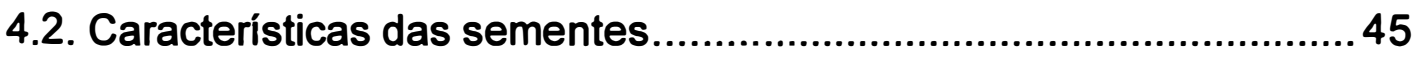

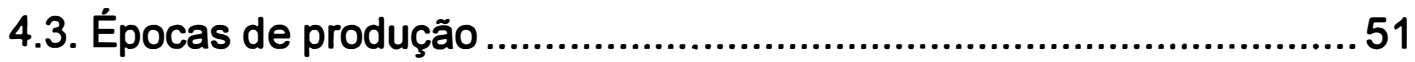

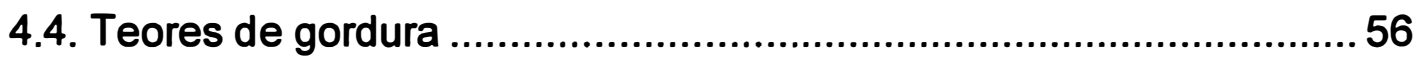

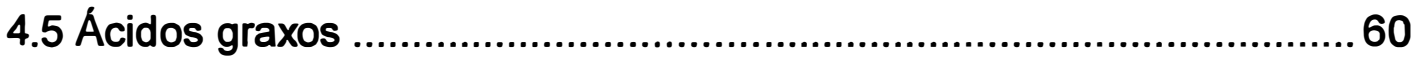

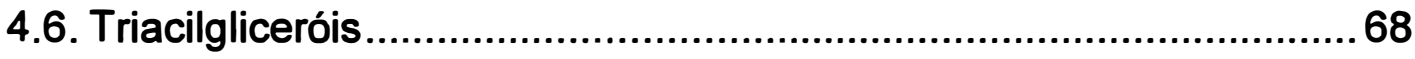

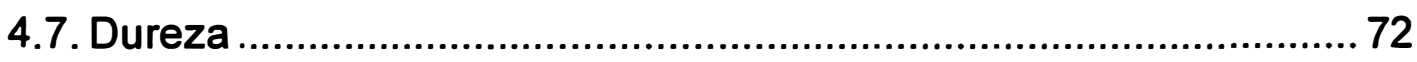

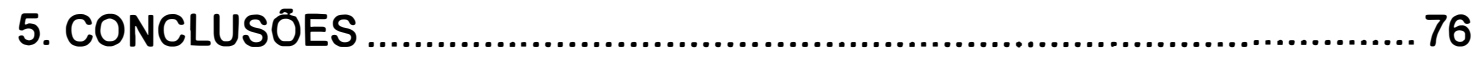

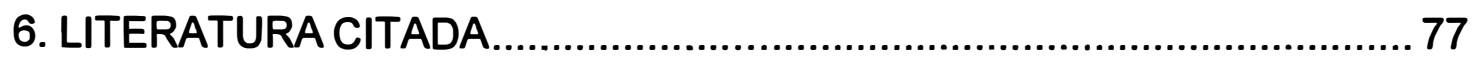




\section{LISTA DE TABELAS}

Página

1 - Produção de cacau por países selecionados, nos períodos de 1990/91 a $1994 / 95$.

2 - Exportação de manteiga de cacau por países selecionados, no período de $1992 / 93$ a $1995 / 96$.

3 - Importações de manteiga de cacau por países selecionados no período de 1992/93 a 1994/95.

4 - Análise química do horizonte A e B de um Latossolo Amarelo Álico A moderado textura argilosa, em condições de cultivo e de mata natural ......30

5 - Valores médios mensais de temperaturas médias (TM), máximas (TMAX) e mínimas (TMIN), precipitação pluviométrica (PPT) e insolação (INS) da região de Pariquera-Açú.

6 - Resumo da análise de variância dos dados de peso, comprimento e diâmetro dos frutos, peso e espessura da casca, peso das sementes com e sem polpa e teor de gordura

7 - Valores biométricos dos frutos e teores de gordura das sementes de dez genótipos de cacau ordenados alfabeticamente

8 - Estimativa de coeficientes de correlação entre os caracteres analisados dos frutos e teores de gordura das sementes por RNM.

9 - Resumo da análise de variância do comprimento, largura e espessura das sementes dos clones estudados

10 - Valores biométricos das sementes de dez clones de cacau ordenados alfabeticamente

11 - Resumo da análise de variância dos dados de peso das sementes com e sem polpa, teor de polpa, peso fresco e seco das sementes com e sem testa e teor de testa

12 - Valores médios do peso da semente com e sem polpa, teor de polpa, peso fresco e seco com e sem testa e teor de testa para dez clones de cacau.....

13 - Estimativa de coeficientes de correlação entre os teores de gordura determinados por Soxhlet e RNM, peso seco das sementes sem testa e teor de testa

14 - Teores médios de gordura de sementes de cacau determinados pelos métodos Soxhlet e RNM de dez genótipos

15 - Teores de ácidos graxos da manteiga de cacau de dez genótipos 
16 - Teores médios de ácidos graxos, triacilgliceróis e valores de dureza (DSC), da manteiga de cacau de nove genótipos, para frutos colhidos na Bahia

17 - Estimativa de coeficientes de correlação entre a dureza (DSC) da manteiga de cacau, ponto de fusão (PF) e os teores de alguns ácidos graxos de dez genótipos

18 - Teores de ácidos graxos saturados e insaturados e relação entre ácidos graxos saturados e insaturados para dez genótipos

19 - Teores médios de ácidos graxos livres, esterois, mono, di e triglicerídeos, para dez genótipos

20 - Valores médios dos teores de triacilgliceróis da manteiga de cacau de dez genótipos

21 - Estimativa de coeficientes de correlação entre a dureza (DSC) da manteiga de cacau, e o ponto de fusão (PF) e alguns triacilgliceróis de dez genótipos

22 - Valores de dureza (DSC) e pontos de fusão da manteiga de cacau de dez genótipos 


\section{LISTA DE FIGURAS}

Páginas

1 - Zoneamento ecológico para a cacauicultura no Estado de

São Paulo

2 - Valores médios mensais de temperaturas médias, máximas

e mínimas, precipitação pluviométrica e insolação, da região de

Pariquera-Açú

3 - Proporções de frutos produzidos mês a mês durante o período

compreendido entre 1982 a 1994, a) IAC 1; b) ICS 95; c) IMC 67

4 - Proporções de frutos produzidos mês a mês durante o período compreendido entre 1982 a 1994, d) P7; e) SCA 12; f) UF 29.

5 - Proporções de frutos produzidos mês a mês durante o período compreendido entre 1982 a 1994, g) UF 613; h) UF 667; i) UF 668

6 - Proporções de frutos produzidos mês a mês durante o período compreendido entre 1982 a 1994, para o genótipo SCA 6

7 - Equação de regressão entre os teores de gordura de sementes de cacau de dez genótipos, determinados por extração em Soxhlet e RNM.. 


\title{
SELEÇÃO dE GENÓTIPOS PARA PRODUÇÃO DE MANTEIGA DE CACAU NO VALE DO RIBEIRA, SÃO PAULO, BRASIL.
}

\author{
Autora: MARIA LUIZA SANT'ANNA TUCCI \\ Orientador: Prof. Dr. LUIZ CARLOS BASSO
}

\section{RESUMO}

Com o objetivo de avaliar o potencial industrial da manteiga de cacau produzida no Estado de São Paulo, bem como a diferença de comportamento entre alguns materiais genéticos, dez genótipos (IAC1, ICS95, IMC67, P7, SCA6, SCA12, UF29, UF613, UF667, UF668) da coleção de germoplasma da Estação Experimental localizada em Pariquera-Açú, a 24 $43^{\prime} \mathrm{S}, 47^{\circ} 53^{\prime} \mathrm{W}, 25$ $m$ de altitude, foram avaliados para teor de gordura, dureza e composição da manteiga. Os frutos de polinização aberta, foram colhidos em maio de 1995 , com exceção do clone ICS95, que foi colhido em junho. As sementes, após haverem sido despolpadas, tiveram a testa removida e foram submetidas à secagem em estufa a $50^{\circ} \mathrm{C}$ por 3 dias. $O$ teor de gordura foi determinado por extração em Soxhlet, após digestão ácida e por ressonância nuclear magnética (RNM). A dureza da gordura foi determinada por calorimetria diferencial de varredura (DSC), representando percentuais de gordura sólida a $16^{\circ} \mathrm{C}$ e também por ponto de fusão. A composição de ácidos graxos e triglicerídeos foi 
estimada por cromatografia gasosa. Foram observadas diferenças significativas entre genótipos para teor de gordura, pelos dois métodos utilizados. Houve correlação altamente significativa entre os métodos $(r=0,74)$. O DSC variou de 75,6 a 88,3 , enquanto os valores do ponto de fusão variaram de 30,1 a $31,6^{\circ} \mathrm{C}$. As diferenças entre genótipos não foram significativas para essas características e os valores obtidos encontram-se dentro dos padrões da indústria. A correlação entre ponto de fusão e DSC não foi significativa. A relação entre ácidos graxos saturados e insaturados variou entre 1,5 a 1,7. Foi observada correlação positiva $(r=0,68)$ significativa entre os teores de ácido esteárico e dureza e correlação negativa $(r=-0,78)$ significativa, entre os teores de ácido oléico e dureza. Os teores dos principais triacilgliceróis (POS, SOS, POP) variaram de 37,4 a $41,2 \% ; 13,2$ a $21,7 \%$ e 21,0 a $27,8 \%$, respectivamente. A soma dos triacilgliceróis $\mathrm{POO}$ e $\mathrm{SOO}$, cujos altos teores são indicativos de gorduras macias, variou de 5,1 a 10,7\%. Foram encontradas correlações positivas altamente significativas entre teores de POS e dureza e correlações negativas entre teores de POO e SOO e dureza. Os resultados indicaram que frutos desenvolvidos durante o período estudado, podem produzir manteiga de cacau comercialmente aceitável e que existe potencial para o melhoramento genético visando aprimorar essa característica. 
SELECTION OF GENOTYPES FOR THE PRODUCTION OF COCOA BUTTER

IN VALE DO RIBEIRA, SÃO PAULO, BRAZIL.

\author{
Author: MARIA LUIZA SANT'ANNA TUCCI \\ Adviser: PROF. DR. LUIZ CARLOS BASSO
}

SUMMARY

With the aim of evaluating the cocoa butter produced in São Paulo State, Brazil, from the industrial stand point, as well as the differences among genotypes, ten genotypes (IAC1, ICS95, IMC67, P7, SCA6, SCA12, UF29, UF613, UF667, UF668) from the germplasm collection of the Experimental Station at Pariquera-Açú, at $24^{\circ} 43^{\prime} \mathrm{S}, 4^{\circ} 53^{\prime} \mathrm{W}, 25 \mathrm{~m}$ altitude, were evaluated for fat content, hardness and composition of cocoa butter. Open - pollinated fruits were harvested in May, 1995 except for genotype ICS95, harvested in June. Fat content was determined by Soxhlet extration and by nuclear magnetic ressonance (NMR). Fat hardness was determined by differencial scanning calorimeter (DSC), and by melting point determination. Fatty acid and triglyceride composition were determined by gas chromatography. Significant differences were observed among genotypes for fat content for both methods with a significant positive correlation between them $(r=0,74)$. DSC values ranged from 75,6 to 88,3 , and the melting point ranged from 30,1 to $31,6^{\circ} \mathrm{C}$, with no significant differences among genotypes for these traits. The ratio saturated: unsaturated fatty acids ranged from 1,5 to 1,7 . There was a significant positive correlation $(r=0,68)$ between stearic acid content and hardness and a significant negative correlation $(r=-0,78)$ between oleic acid content and hardness. Major triacylglycerols (POS, SOS, POP) content ranged from 37,4 to $41,2 \% ; 13,2$ to $21,7 \%$ and 21,0 to $27,8 \%$, respectively. The amounts of POO 
and SOO indicative of soft fats, ranged from 5,1 to $10,7 \%$. There was a significant positive correlation between POS content and hardness and a negative correlation between $\mathrm{POO}$ and SOO content and hardness. The results show that fruits grown during the season studied could produce cocoa butter suitable for industrial purposes and that there is a possibility for improvement of this characteristic by breeding. 


\section{INTRODUÇÃO}

Referências relativas à possibilidade do cultivo do cacaueiro no Estado de São Paulo remontam ao início deste século (Granato, 1904, 1908, 1909; D'Utra, 1909). A partir da década de 50, através da introdução de materiais genéticos realizada pelo pesquisador João Cunha, do Instituto Agronômico (IAC), começaram a ser instaladas coleções de germoplasma de cacau nas Estações Experimentais do Instituto Agronômico (IAC), localizadas em Pariquera-Açu e Ubatuba.

$\mathrm{Na}$ década de 70 , com a intenção de recolocar o Brasil na liderança mundial da produção de cacau, o governo brasileiro aprovou e executou um ambicioso programa de expansão para a cacauicultura: o PROCACAU, 1976-1985 (Menezes e Carmo-Neto, 1993). Da estratégia adotada para a consecução da meta proposta, constava o aumento da produção através da expansão de novas áreas.

Nesse contexto, foi possível ao Estado de São Paulo participar do programa nacional de expansão, com previsão de área plantada com cacaueiros, de 10.000 ha, correspondendo a 10.000 .000 de plantas. A fim de coordenar e executar o programa de implantação da cacauicultura comercial em nível estadual, foi oficializado em 1978 o Plano de Expansão à cacauicultura no Estado de São Paulo (PECASP), cuja meta era o estabelecimento da cacauicultura comercial, inicialmente no Litoral Paulista, incluindo a região do Vale do Ribeira considerada como a de melhor potencial e em seguida em regiões do interior do Estado consideradas aptas ao cultivo do cacaueiro (SECRETARIA DA AGRICULTURA DO ESTADO DE SÃO PAULO, 1974) (Figura 1). 
do cacaueiro (SECRETARIA DA AGRICULTURA DO ESTADO DE SÃO PAULO, 1974) (Figura 1).

O programa a princípio despertou o interesse de empresários agrícolas e nos anos 80 a cacauicultura chegou a ocupar no Estado, aproximadamente 4.000 ha (Nogueira, 1986). No entanto, vários fatores contribuíram para a alteração desse quadro e a partir do final dessa mesma década, a cacauicultura em São Paulo passou a se constituir em tema bastante polêmico.

Entre as questões levantadas, além da produtividade, enfatizavase um aspecto relacionado à qualidade do produto final. Questionava-se a viabilidade de se utilizar manteiga de cacau proveniente de frutos produzidos no Estado de São Paulo, particularmente do Vale do Ribeira, onde se concentrava a produção, pela indústria chocolateira. A argumentação se fundamentava no fato de que a latitude da região $\left(24^{\circ} 43^{\prime} \mathrm{S}\right)$, elevada se comparada às regiões tradicionais de cultivo, poderia acarretar condições climáticas, especialmente temperaturas, que propiciariam a síntese de manteiga de cacau com baixo grau de dureza e portanto inadequada à fabricação de chocolate. Além disso, frutos e sementes poderiam ter características alteradas pelo efeito do clima.

O presente trabalho teve como objetivo, determinar as características dos frutos e o teor, composição de ácidos graxos, composição triglicerídica e dureza da manteiga de cacau de 10 genótipos da coleção de germoplasma da Estação Experimental de Pariquera-Açú (SP), para verificar a possibilidade de sua utilização industrial. 


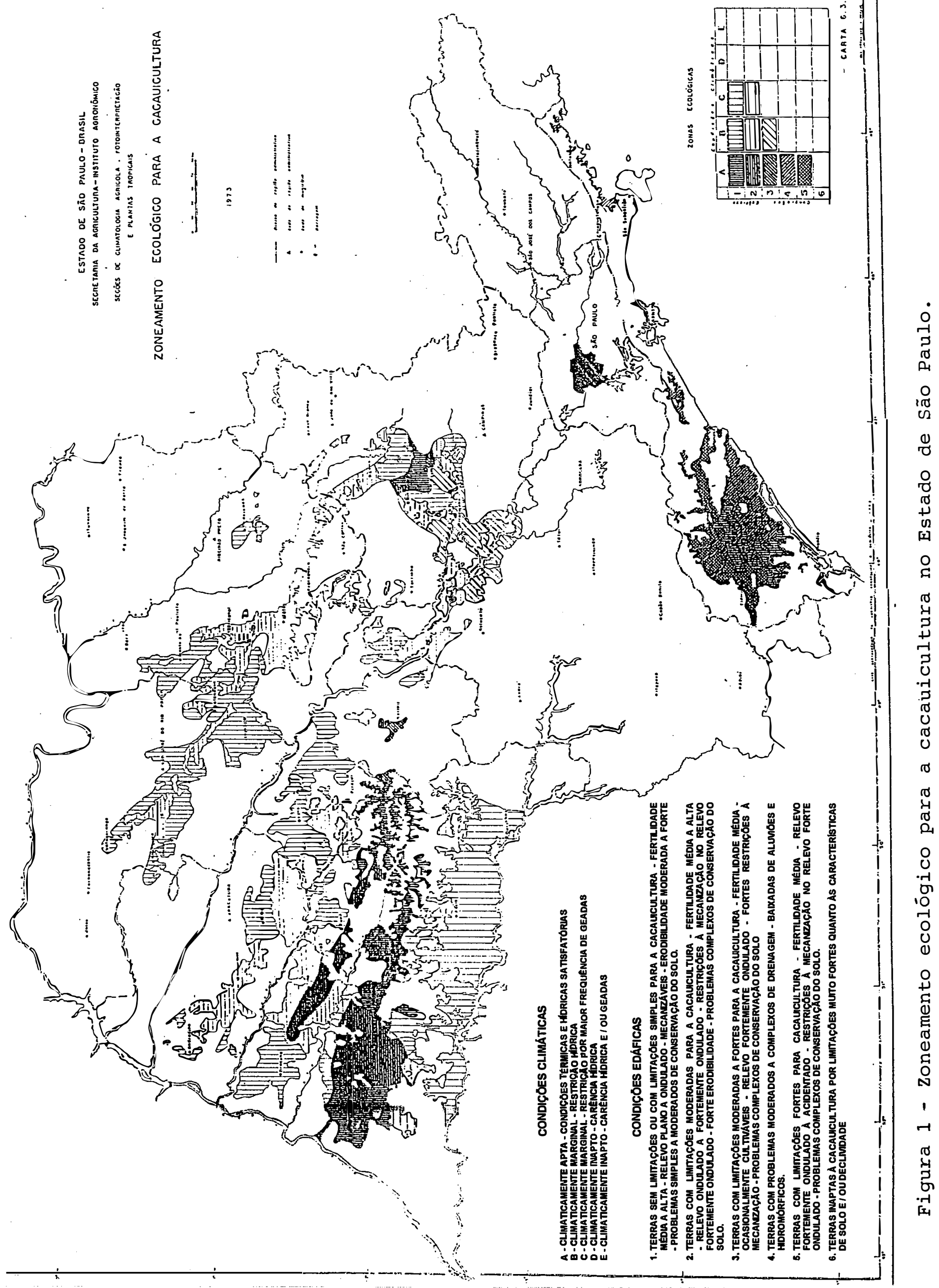




\section{REVISÃO DE LITERATURA}

\subsection{Origem e distribuição geográfica do cacaueiro}

Através dos tempos o cacaueiro e seus frutos têm despertado o interesse de tantos quantos puderam ter a oportunidade de conhecê-los. Sua história é repleta de lendas e mitos, cujas origens remontam a tempos imemoriais. Os astecas atribuiam ao cacaueiro origem divina. Este seria originario do paraiso e dos jardins do deus Quetzalcoatl, teria sido trazido à Terra para proporcionar prazer aos homens.

A planta era cultivada muito antes da chegada dos europeus à América pelos maias, no México e na Guatemala, constituindo-se nos primeiros povos conhecidos a considerar as qualidades valiosas de suas amêndoas. Além deles, também os astecas consumiam cacau à época do descobrimento (Wood, 1985).

O gênero Theobroma ao qual pertence o cacaueiro, ocorre em estado nativo na Bacia Amazônica e em outras regiões tropicais da América do Sul e Central e as regiões do alto Amazonas têm sido consideradas como a origem do cacaueiro. No entanto, segundo Wood (1985), parece mais correto considerar essa região, onde é encontrada grande variação nos caracteres morfológicos e fisiológicos, como o centro primário de diversidade e a América Central, como um centro secundário.

Para Cruz et al. (1995), os cultivos de cacau podem ter sido abandonados pelos maias após a colonização europeia, com alguns poucos 
plantios permanecendo isolados, protegidos pelos seus descendentes. Populações redescobertas no México, podem ser tanto derivadas de cacaueiros nativos não detectados anteriormente ou remanescentes dos antigos cultivares maias.

Atualmente o cacaueiro encontra-se como cultivo comercial, em regiões situadas entre as latitudes $15^{\circ} \mathrm{N}$ e $20^{\circ} \mathrm{S}$, sendo que segundo Wood (1985), $75 \%$ da produção mundial é originária de regiões situadas em uma faixa entre $8^{\circ}$ ao norte e ao sul do Equador. A área mais extensa além de $8^{\circ} \mathrm{S}$, é representada pelo Estado da Bahia, em que a principal região produtora situa-se entre 13 e $18^{\circ} \mathrm{S}$.

As áreas geográficas produtoras são: África, detendo em 1994/95 cerca de $61,1 \%$ da produção mundial, com 1436,5 mil toneladas, Américas Central, Norte e Sul produzindo 504,3 mil toneladas, correspondendo a $21,5 \%$ da produção mundial e Ásia e Oceânia com 408,2 mil toneladas, equivalentes a $17,4 \%$ da produção mundial. Em ordem decrescente, os maiores países produtores no período 1994/95 foram Costa do Marfim, Gana, Indonésia, Brasil, Nigéria e Malásia (Tabela 1), detendo juntos $80,3 \%$ da produção mundial. No Brasil, o Estado da Bahia é responsável por $90 \%$ da produção. No mesmo periodo considerado, a produção mundial alcançou 2.349,0 mil toneladas, enquanto a brasileira correspondeu a 225,0 mil toneladas. O Brasil, de segundo maior produtor no período 1993/94, ocupa atualmente o quarto lugar, tendo sido superado por Gana e Indonésia, país que desde o início da década atual vem despontando como grande produtor. A Costa do Marfim vem mantendo a primeira posição, com estimativa de 1.200 mil toneladas em 1995/96 e previsão de 1.000 mil toneladas para o período de 1996/97 (International Cocoa Organization, 1996). 
Tabela 1 - Produção ${ }^{1}$ de cacau por países selecionados, nos períodos de 1990/91 a 1994/95 (International Cocoa Organization, 1996).

\begin{tabular}{lccccccc}
\hline País & $1990 / 91$ & $1991 / 92$ & $1992 / 93$ & $1993 / 94$ & $1994 / 95$ & $\begin{array}{c}1995 / 96 \\
\text { (estimativa) }\end{array}$ & $\begin{array}{c}1996 / 97 \\
\text { (previsão) }\end{array}$ \\
\hline Costa do Marfim & 804,4 & 747,0 & 800,0 & 840,0 & 850,0 & $1.200,0$ & $1.000,0$ \\
Gana & 293,4 & 242,8 & 312,1 & 254,7 & 309,4 & 403,8 & 330,0 \\
Indonésia & 150,0 & 180,0 & 240,0 & 260,0 & 240,0 & 295,0 & 330,0 \\
Brasil & 368,1 & 306,2 & 308,6 & 282,7 & 225,0 & 230,0 & 195,0 \\
Nigéria & 160,0 & 110,0 & 145,0 & 135,0 & 142,7 & 147,0 & 140,0 \\
Malásia & 221,0 & 220,0 & 225,0 & 205,0 & 120,0 & 105,0 & 120,0 \\
\hline Total mundial & $2.506,8$ & 2277,9 & 2484,5 & 2436,1 & 2349,0 & 2900,4 & 2622,0 \\
\hline
\end{tabular}

${ }^{1}$ Mil toneladas

\subsection{Classificação botânica}

O cacaueiro pertence à ordem Malvales e à família das Esterculiáceas. Os astecas e outros grupos de lingua nahuatl chamavam o cacaueiro de cacaohoaquahuitl; seus frutos de cacahoacentli e suas sementes de cacaoatl (Paradis, 1979). Desse nome das sementes deriva a palavra "cacao", nome da espécie, atualmente empregada universalmente e usada pela primeira vez em 1700, por Tournefort que a reteve como nome de gênero. No entanto Lineu, em 1737, preferiu substitui-la por Theobroma que significa manjar dos deuses, em alusão à mencionada origem divina atribuída ao cacaueiro (Braudeau, 1970).

Segundo Enriquez (1985), é possível classificar os cacaus cultivados em três grandes grupos, que se referem a complexos genéticos amplos, aos quais correspondem as variedades: a) Criollos: frutos verdes ou 
vermelhos, cilíndricos, casca rugosa, delgada ou grossa, sementes brancas ou ligeiramente pigmentadas, cilíndricas ou ovais; b) Forasteros: frutos geralmente verdes, ovais, cascas lisas ou ligeiramente rugosas, sementes violeta, sendo a variedade mais difundida, representando $80 \%$ da produção mundial; c) Trinitários: constituem as populações híbridas de cruzamentos espontâneos de Criollos e Forasteros e seus frutos e sementes têm características intermediárias entre os grupos que Ihes deram origem. Estudos recentes realizados com marcadores moleculares por Figueira et al. (1994), envolvendo genótipos de T.cacao representando todas as raças e várias origens, indicaram não haver congruência com a classificação tradicional nos três grupos mencionados.

\section{3. $O$ fruto}

O fruto do cacaueiro é uma baga indeiscente, que apresenta um pericarpo composto de três partes bem diferenciadas: epicarpo, carnoso e espesso; mesocarpo, fino e duro, mais ou menos lignificado; endocarpo, carnoso, de espessura variável. $O$ fruto é sustentado por um pedúnculo lenhoso, procedente do engrossamento do pedicelo da flor. Enquanto jovem, apresenta, tal como o ovário, cinco compartimentos, em cada um dos quais estão as sementes regularmente repartidas. Quando o fruto amadurece, desaparecem os compartimentos, apenas subsistindo uma cavidade única, na qual as sementes, envoltas por uma polpa mucilaginosa espessa, aparecem normalmente dispostas em cinco fileiras. Em geral, um fruto pode conter de $\mathbf{3 0}$ a 40 sementes (Braudeau, 1970).

A cor, forma e tamanho dos frutos são extremamente variáveis segundo os materiais genéticos. A cor dos frutos imaturos varia do verde, dos Forasteros amazônicos ao vermelho dos grupos Criollo e Trinitário. Quando o fruto amadurece, o verde passa a amarelo e o vermelho passa a alaranjado. $O$ tamanho é determinado pelo comprimento, que pode variar de 10 a $30 \mathrm{~cm}$ 
(média de 12 a $15 \mathrm{~cm}$ ) e por sua largura, igualmente muito variável (média de 7 a $9 \mathrm{~cm}$ ). A forma varia desde a cilíndrica com extremidade pontiaguda do grupo Criollo até a forma amelonada dos frutos do grupo Trinitário (Braudeau, 1970).

O tempo transcorrido desde a polinização até a colheita do fruto varia com os genótipos e com o ambiente (Enriquez, 1985). Segundo Alvim (1977), esse intervalo varia de acordo com as temperaturas registradas durante o desenvolvimento dos frutos. Frutos do "temporão", que se desenvolvem durante os meses mais quentes (colhidos entre abril e agosto), amadurecem em 140 dias, enquanto frutos da "safra" (colhidos entre setembro e janeiro), necessitam de 167 a 205 dias para amadurecer.

\subsection{A semente}

As sementes são revestidas por uma polpa mucilaginosa branca, rica em açúcares, que desempenha papel muito importante no preparo do cacau comercial, durante o processo conhecido como fermentação. Os cotilédones apresentam numerosos lóbulos imbricados uns com outros, recobertos por uma finissima película translúcida, brilhante, que representa os vestígios do endosperma (Braudeau, 1970). Estão reunidos em sua base a uma radícula, cujo parênquima é atravessado por um sistema vascular (Chatt, 1953) e a uma gêmula rudimentar, que constituem o que se chama impropriamente de "germe" da semente de cacau. Os cotilédones estão envoltos por uma cobertura delgada mas resistente, de cor rosada, apresentando muitas nervuras, proveniente do desenvolvimento dos tegumentos do óvulo, denominada testa (Braudeau, 1970).

As sementes variam bastante em sua forma, tamanho e coloração, dependendo do material genético e o peso úmido pode variar de 0,7 a $3,7 \mathrm{~g}$. A coloração do cotilédone é um caráter genético típico e está associada ao tipo de cacau. Pode variar do branco (Criollo), até o violeta-escuro (Forastero), com diferentes tonalidades e distribuição de cores. Estão presentes várias espécies 
de polifenóis, responsáveis pelo sabor adstringente das sementes frescas. A antocianina, responsável pela coloração violeta dos cotilédones dos cacaus Forastero e Trinitário, não está presente no cacau Criollo (Enriquez, 1985).

Um exame histológico dos cotilédones frescos permite distinguir três tipos de células: a) celulas epidérmicas dispostas em uma camada mononuclear; b) células parenquimatosas de reserva que constituem ao redor de $90 \%$ dos tecidos dos cotiledones e são incolores, contendo cristais de uma matéria graxa chamada manteiga de cacau, proteínas em forma de grãos de aleurona e grãos de amido; c) células com polifenóis (taninos, catequinas, antocianinas, leucoantocianinas) que constituem cerca de $10 \%$ dos tecidos dos cotilédones e que são responsáveis por sua coloração. Essas células contém também as purinas (teobromina e cafeína). É importante assinalar que nem as células com pigmentos nem as de reserva contém substâncias que darão origem ao aroma chocolate. As sementes não fermentadas são incapazes de produzir aroma, o que confirma que as substâncias precursoras do aroma do cacau unicamente se formam durante o processo de fermentação (Braudeau, 1970).

\subsection{O chocolate}

A palavra chocolate tem origem mexicana, sendo derivada de "chocolatl", expressão onomatopéica, cuja pronúncia se assemelhava ao som produzido pelo moínho de mão que os nativos da América Central usavam para moer as amêndoas de cacau ("Historicus", 1892), para obter uma pasta denominada cacau, com a qual preparavam a bebida, o chocolate (Peeters, 1979). No entanto, existe outra teoria a respeito (Hardy, 1961).

Desde os tempos em que era considerado alimento dos deuses pelos nativos até o presente, o chocolate passou por muitas transformações. Tal como o preparavam os povos da América Central, não suscitou o entusiasmo dos conquistadores espanhóis: tratava-se de uma bebida amarga, 
adicionada de pimenta e urucum (Bixa orellana L.), como corante (Peeters, 1979) e sua aceitação não foi imediata e não ocorreu sem suscitar muitas controvérsias (Barrau, 1979). Somente após 1519 é que os europeus descobriram o prazer da degustação do cacau (Paradis, 1979), juntando a êle açúcar (Peeters, 1979).

O cacau é talvez aquilo que representa melhor a perplexidade dos europeus diante de uma planta alimentícia proveniente da América. Nenhuma planta americana, nem mesmo o tabaco, suscitou tanto entusiasmo. 0 primeiro conhecido do trio chá-café-chocolate, este permaneceu durante muito tempo um produto de luxo na Europa, mas tornou-se rapidamente uma bebida popular nas colônias da América tropical. Durante o período entre os séculos XVI e XVIII na Europa, o chocolate foi consumido como bebida. Esse foi o sentido adotado pelos espanhóis e a seu lado, os outros europeus (Peeters, 1979).

Segundo Chatt (1953), em 1763, na Enciclopédia de Diderot e d'Alembert, uma ilustração de uma fábrica francesa de chocolate apareceu, na qual uma prensa para desengordurar cacau é mostrada. Mais ou menos ao mesmo tempo, foi observado que cacau parcialmente desengordurado, produzia o melhor chocolate.

No entanto, foi necessário esperar até a segunda metade do século XIX para ver seu uso generalizado em confeitaria, tal como nós o conhecemos hoje (Peeters, 1979). Em 1828 van Houten, na Holanda usou uma prensa para remover uma parte da manteiga de cacau das amêndoas produzindo um pó contendo $22-25 \%$ de gordura, o qual era mais fácil de ser digerido. A disponibilidade da manteiga de cacau permitiu a obtenção do chocolate tal como é conhecido hoje, o qual é basicamente composto dos cotilédones secos ou nibs, açúcar e manteiga de cacau adicionada, sendo que essa adição de manteiga de cacau extra o torna fácil de ser moldado. Assim se tornou possivel a confecção de chocolate em barras de boa aparência e textura, bem como a possibilidade de se cobrir outras confecções com chocolate. Esse processo foi o primeiro dos mais importantes avanços 
tecnológicos que conduziram à grande variedade de produtos de cacau disponiveis hoje (Wood, 1985).

A manufatura desse "chocolate comestivel" começou apenas em 1847, quando foi vendido por Fry \& Sons. Em 1849, a firma Cadbury Brothers colocou amostras do novo produto em exibição (Chatt, 1953).

Outro desenvolvimento tecnológico importante foi a mistura de sólidos de leite à massa de cacau e açúcar para obter chocolate ao leite o qual foi inventado por Daniel Peter de Vevey na Suiça e foi primeiramente produzido em 1876 (Wood, 1985).

\subsection{A manteiga de cacau}

O cacaueiro consiste na única fonte de manteiga de cacau, matéria prima fundamental da indústria chocolateira e cosmética, que apresenta característica físico-química única entre as gorduras vegetais, estreitamente relacionada aos teores dos ácidos graxos e triglicerídios. De sua composição, participam ácido palmítico (16:0), esteárico (18:0) e oléico (18:1), aproximadamente em proporções iguais e quantidade menor de ácido linoléico (18:2). Os triacilgliceróis, representam as unidades químicas da manteiga de cacau e desses, os mais importantes apresentam a posição $s n-2$ ocupada por um ácido graxo insaturado basicamente oléico, enquanto as posições $s n-1$ e sn-3 são predominantemente ocupadas por ácidos graxos saturados. Assim, oleopalmitoestearina (POS), oleodiestearina (SOS) e oleodipalmitina (POP), são os três principais triacilgliceróis da manteiga de cacau (Wood, 1985).

As características de fusão da manteiga de cacau a tornam a gordura vegetal preferida para a manufatura do chocolate. À temperatura ambiente $\left(20^{\circ} \mathrm{C}\right)$, a manteiga de cacau é um sólido que começa a amolecer a $30^{\circ} \mathrm{C}$, fundindo completamente à temperatura ligeiramente inferior à temperatura corporal. As características de fusão da manteiga de cacau são 
devidas à sua composiçăo gliceridica única, consistindo de 2,7 a $12,5 \%$ trigliceridios tri-saturados, 67,5 a $81,3 \%$ mono-insaturados, 15,3 a $27,0 \%$ diinsaturados, e 0,7 a 2,1\% tri-insaturados. A composição de ácidos graxos consiste de 24,4 a $28,6 \%$ de ácido palmítico, 34,2 a $36,2 \%$ esteárico, 33,4 a $38,1 \%$ oléico, e 1,8 a $3,6 \%$ linoléico. A manteiga de cacau é mais valiosa que os sólidos de cacau porque tem múltiplos usos e mais manteiga que sólidos é usada na manufatura do chocolate. (Janick, 1986).

Minnifie (1989), define os seguintes tipos de manteiga de cacau: a) Manteiga de cacau prime pressed, definida como a gordura obtida de cotilédones de cacau de boa qualidade, livres de testa, por meio de prensagem mecânica (hidráulica) sem nenhuma refinação subsequente que não a filtração; b) Manteiga de cacau expeller-pressed, em que o nib (cotilédone) é normalmente submetido a ação de vapor para provocar a separação, sendo quimicamente a mesma que a prime pressed, mas usualmente sujeita a processo de refinação; c) Manteiga de cacau extraída por solvente da torta após o processo expeller ou de resíduos de cacau ou chocolate, necessitando sempre de processo de refinação. Como produto comercial há divergências se ela pode ser aceita como manteiga de cacau.

A tabela 2 apresenta a participação percentual dos maiores exportadores de manteiga de cacau no mercado mundial, durante os períodos de 1992/93 a 1994/95. Observa-se que a Holanda é o país maior exportador, sendo seguida pelo Brasil e a Malásia. Nota-se que apenas quatro países detém mais de $60 \%$ das exportações de manteiga de cacau. Segundo Duarte (1987) esse mercado, assim como o mercado de amêndoas, apresenta comportamento oligopolista e o maior dos exportadores de manteiga não é produtor de cacau, mostrando que é importante a transformação de cacau em derivados, nos países importadores de amêndoa. No entanto há por parte de alguns países importadores de manteiga um processo de reexportação, isto é, o país importa a manteiga, faz um reprocessamento às vezes misturando-a com manteiga de origem diferente ou com óleo hidrogenado e a reexporta com 
as caracteristicas do mercado comprador. A manteiga de cacau caracteriza-se no mercado como o derivado de cacau de preços mais altos, em média chegando a custar quase três vezes o preço da amêndoa. Assim como os outros derivados e a propria amêndoa, o preço da manteiga de cacau sofre flutuações decorrentes da instabilidade que é característica de produtos primários e seus derivados. São poucos os estudos referentes aos mercados de derivados de cacau, quando tratados separadamente. Geralmente , os derivados são incluídos nas pesquisas através de conversão de suas quantidades para equivalentes em termos de amêndoa (Duarte, 1987). 
Tabela 2 - Exportação ${ }^{2}$ de manteiga de cacau por países selecionados, no período de 1992/93 a 1995/96 (International Cocoa Organization, 1996).

\begin{tabular}{lrrr}
\hline País & \multicolumn{1}{c}{$1992 / 93$} & \multicolumn{1}{c}{$1993 / 94$} & \multicolumn{1}{c}{$1994 / 95$} \\
\hline França & 15.908 & 25059 & 34.177 \\
Alemanha & 17.408 & 13.904 & 8.870 \\
Holanda & 128.216 & 136.193 & 146.717 \\
Reino Unido & 5.288 & 7.536 & 5.763 \\
Costa do Marfim & 24.488 & 18.273 & 38.232 \\
Gana & 5.750 & 5.900 & 3.900 \\
Brasil & 38.778 & 33.508 & 23.423 \\
Indonésia & 16.214 & 15.158 & 17.132 \\
Malásia & 38.544 & 40.044 & 39.311 \\
Cingapura & 17.900 & 19.195 & 19.153 \\
\hline Total mundial & 368.970 & 374.600 & 398.430 \\
\hline${ }^{2}$ Toneladas & & &
\end{tabular}

$\mathrm{Na}$ Tabela 3 estão expressos os valores das importações de manteiga de cacau por países selecionados durante os períodos entre 1992/93 e 1994/95.

No aspecto financeiro, as exportações brasileiras de manteiga de cacau totalizaram no período de janeiro a dezembro de 1991 , US $\$ 83,8$ milhões, para um volume de $28.679,7$ toneladas, ao preço médio de US\$ 2.923,00. Desse total, a Bahia exportou $27.140,7$ toneladas, ao preço médio de US $\$ 2,927$, no valor total de US $\$ 79,4$ milhões. Algumas indústrias estimuladas pelo alto preço da manteiga (que chegou a quase três vezes o valor da amêndoa), dedicaram-se à compra de cacau diretamente na lavoura. (Menezes e Carmo-Neto, 1993). 
Tabela 3 - Importações ${ }^{3}$ de manteiga de cacau por países selecionados no período de 1992/93 a 1994/95 (International Cocoa Organization, 1996).

\begin{tabular}{lrrr}
\hline País & \multicolumn{1}{c}{$1992 / 93$} & \multicolumn{1}{c}{$1993 / 94$} & \multicolumn{1}{c}{$1994 / 95$} \\
\hline Bélgica / Luxemburgo & 28.989 & 32.512 & 24.859 \\
França & 28.012 & 36.992 & 38.203 \\
Alemanha & 37.792 & 53.511 & 67.036 \\
Holanda & 42.323 & 47.228 & 38.540 \\
Reino Unido & 28.254 & 32.389 & 33.726 \\
Suiça & 16.146 & 17.908 & 17.432 \\
Argentina & 6.010 & 6.480 & 7.150 \\
Canadá & 11.830 & 10.615 & 11.671 \\
EUA & 86.473 & 57.894 & 58.970 \\
\hline Total mundial & 378.680 & 388.440 & 384.610 \\
\hline
\end{tabular}

s Toneladas

\subsection{Teor de manteiga de cacau}

Com respeito ao teor de manteiga de cacau, Toxopeus e Wessel (1970), observaram diferenças de até $2 \%$ (até $8 \%$ em anos de seca mais drástica), em função da precipitação pluviométrica. Vello, Garcia e Magalhães (1972), trabalhando com híbridos, encontraram teores de gordura variando entre 55 e $58 \%$. Efeitos tanto do clone materno como do pólen, resultando em diferenças significativas com relação à porcentagem de gordura, foram observados por Toxopeus e Jacob (1968) e Beek, Eskes e Toxopeus (1977). Pires et al. (1994), trabalhando com 276 genótipos, encontraram teores de 
gordura entre 45,6 e 59,8\%, concluindo que existe variabilidade genética para seleção para alto teor de gordura.

Para o Estado de São Paulo, dados a respeito da variação do teor de manteiga de cacau entre genótipos são escassos.

\subsection{Síntese da manteiga de cacau}

Os ácidos graxos são sintetizados a partir de acetil-CoA por uma série de reações localizadas nos plastídeos, que incluem a reunião, via reações de aciltransferase de três acil-ácidos graxos à molecula do glicerol para formar triacilglicerol, a forma de reserva dos ácidos graxos nas sementes (Ohlrogge, 1994). Deve ser levado em consideração o fato de que a distribuição dos ácidos graxos e conteúdo e proporção dos diferentes acillipídios em tecidos vegetais podem variar consideravelmente durante 0 desenvolvimento, maturação ou senescência e que fatores ambientais como luz, temperatura, podem alterar profundamente a composição de lipídios endógenos (Harwood, 1980).

Segundo Harwood e Page (1994), o desenvolvimento de uma semente oleaginosa tipicamente segue 3 fases: a) envolve rápida divisão celular durante a qual é sintetizado pouco triacilglicerol, cuja composição de ácidos graxos tende a assemelhar-se àquela dos fosfolipídios e glicolipídios de membrana, mais do que ao óleo de reserva final. Assim, o triacilglicerol em embriōes muito jovens tenderá a ter altos teores de ácidos linoléico e linolênico independentemente da espécie de planta; b) a síntese de triacilglicerol está no máximo, sendo sintetizados os ácidos graxos característicos do óleo final; c)durante a terceira fase, pouca síntese adicional de óleo é observada.

Chatt (1953), relatava que a gordura das sementes do cacaueiro era sintetizada a partir de açúcares, não tendo sido isolado nenhum produto intermediário e que nos estádios iniciais predominavam ácidos graxos livres, com formação de trialcilgliceróis em um estadio comparativamente mais tardio 
e aumento na proporção de ácidos graxos insaturados a medida que a maturação prosseguia. A gordura acumulava rapidamente nos cotilédones entre $087^{\circ}$ e $143^{\circ}$ dias.

Dittmar e Duarte (1958), encontraram diferenças na insaturação da manteiga de cacau proveniente de frutos verdes e maturos, com os verdes produzindo manteiga de cacau mais insaturada que os maduros, ou seja a insaturação diminuia durante a maturação dos frutos.

Estudos sobre as alterações na composição lipídica da manteiga de cacau, de sementes colhidas a intervalos desde 110 dias pós-polinização (DAP), até a maturação (180 dias), indicaram que em todos os estádios de desenvolvimento os triacilgliceróis predominaram, correspondendo a $69-96 \%$ dos lipídios totais. Entre 120 a 150 DAP a síntese de triacilgliceróis ocorreu a uma taxa praticamente linear, estabilizando no período final do desenvolvimento. $O$ teor de lipídios com base na matéria seca triplicou entre 110 e 130 DAP, passando de $16,2 \%$ com base na matéria seca, para 50,1\%. A composição de ácidos graxos sofreu alterações principalmente entre 110 e 140 DAP, representadas particularmente pelo aumento no teor de ácido esteárico e decréscimo em ácido linoléico, estabilizando em 150 DAP. Os teores mais altos de ácido linoléico nos estádios iniciais, refletem a dominância de lipídios associados a membranas, que contém altos níveis de ácidos graxos insaturados (Lehrian e Keeney, 1980).

Esses resultados foram coerentes com as observações de Patel et al. (1994), trabalhando com embriōes de cacau em desenvolvimento entre 95 e 145 DAP. Durante esse intervalo, os teores de ácido linoléico e palmítico decresceram, e os teores de ácido esteárico e oléico cresceram. Após 115 DAP, ácidos esteárico, palmítico e oléico acumularam a uma taxa aproximadamente igual e a composição de ácidos graxos se assemelhou àquela da manteiga de cacau. A insaturação decresceu entre 95 e 115 DAP e então estabilizou. Assim, a composição lipídica mudou do tipo-membrana para 
tipo-manteiga de cacau em apenas 20 dias dos 170 dias requeridos para o embrião alcançar a maturidade.

\subsection{Influência das condições ambientais na qualidade da manteiga de cacau}

A influência do ambiente sobre a produção de óleos e gorduras de várias espécies vegetais, tem sido bastante estudada desde as primeiras décadas deste século. McNair (1965), em ampla revisão sobre o tema, concluiu que conforme as plantas se desenvolvem em regiōes mais próximas do Equador, o grau de insaturação de suas gorduras decresce, em função principalmente do aumento da temperatura do ar.

Estudos sobre a influência da temperatura na composição de lipídios vegetais foram realizados em soja (Agrawal e Vyas, 1971; Martin et al. 1986; Rennie e Tanner, 1989; Cheesbrough, 1989;1990; Wilcox e Cavins, 1992; Dornbos e Multen, 1992), amendoim (Golombeck et al., 1995), girassol (Harris et al, 1978; 1980; Unger, 1980; Silver et al., 1984; Sailer, 1986; Haro e Fernandez-Martinez, 1991; Garcés et al., 1994), açafrão (Yermanos et al., 1967; Hill e Knowles, 1968), maracujá (López, 1980). Todos esses autores observaram que o abaixamento da temperatura provocou aumento na insaturação dos lipídios. Observação de mesma natureza foi feita para lipídios de membranas, em microorganismos, por Wada et al. (1993), que concluiram que a regulação da composição de ácidos graxos dos lipidíos de membrana em resposta a uma alteração na temperatura ambiente, pode ser explicada em termos de regulação da fluidez que é necessária para manter o funcionamento adequado das membranas biológicas.

Para o cacaueiro, Dantas (1955) verificou que o grau de insaturação avaliado pelo índice de iodo para as manteigas de cacau brasileiras era mais elevado que os dos produtos similares de outros países 
produtores, a tal ponto que o produto brasileiro chegou a ser em certa ocasião, julgado na França como fraudado pela gordura de ilipé, que é extraida das sementes de Bassia longifolia L. Resultados semelhantes foram obtidos por Wirth ${ }^{1}, 1955$, citado por Dittmar e Duarte (1958a) Dittmar e Duarte (1958b), não podendo os autores àquela época, concluir a respeito das razões para esse fato.

Hildich $^{2}, 1956$, citado por Dittmar e Duarte (1958a), havia pela primeira vez mencionado que o ponto de fusão da manteiga de cacau dependeria também da estrutura particular dos trigliceridios, sendo predominante para essa gordura o seguinte sistema: um ácido insaturado para dois ácidos saturados.

O grau de insaturação da manteiga de cacau, é inversamente proporcional ao ponto de fusão e nível de dureza, características importantes do ponto de vista industrial. Os teores de ácidos graxos e sua localização na molécula do triacilglicerol são determinados durante o processo de síntese da manteiga de cacau, podendo variar segundo o material genético e condições ambientais (Dimick, 1991).

Berbert e Alvim (1972), entre os fatores ambientais avaliados, que afetam diretamente a composição da manteiga de cacau, observaram que temperaturas mais altas durante a fase de desenvolvimento dos frutos levaram ao menor grau de insaturação dos ácidos graxos. A influência de temperaturas mais elevadas durante o desenvolvimento dos frutos no aumento da saturação e consequentemente da dureza da manteiga de cacau, também foi observada por Berbert (1976) e Lehrian, Keeney e Butler (1980).

Chaiseri e Dimick (1989), encontraram diferenças na composição triglicerídica e na dureza de manteigas de cacau provenientes de diferentes

\footnotetext{
${ }^{1}$ Wirth, W. Zucker und Süsswarenwitschaft, 8:801, 1955.

${ }^{2}$ Hilditch, T.P. The Chemical Constitution of Natural Fats. 3.a ed., p. 349, Chapman and Hall, Ltd., London 1956.
} 
regiões geográficas, tendo classificado a proveniente da Bahia, entre as mais macias, em contraposição à da Malásia, considerada dura.

Para o Estado de São Paulo, Berbert e Alvim (1972), estudaram o grau de saturação da manteiga de cacau de sementes provenientes de frutos colhidos no mês de julho, em Ribeirão Preto (SP), a $21^{\circ} 11^{\prime} \mathrm{S}, 47^{\circ} 48^{\prime} \mathrm{W}$ e encontraram um grau de insaturação superior ao apresentado por sementes provenientes da Bahia, Amazonas e Pará.

\subsection{Gordura de outras espécies do gênero Theobroma}

O gênero Theobroma possui um total de 22 espécies e ainda que todas elas possam apresentar interesse, algumas podendo inclusive servir para fabricação de chocolate, a única cultivada em grande escala para essa finalidade é Theobroma cacao L. A maioria das espécies é explorada em estado selvagem localmente pelas populações nativas que às vezes cultiva algumas delas (Braudeau, 1970).

Na semente fresca do cupuaçu (Theobroma grandiflorum L.) produzido na Bahia encontraram-se altos índices de gordura $(61,0 \%)$ e ponto de fusão de $32,5^{\circ} \mathrm{C}$ (Ribeiro et al., 1992).

Análise comparativa das sementes de cupuaçu (Theobroma grandiflorum L.) e cacau (Theobroma cacao L.) , mostrou diferenças na composição de ácidos graxos (ácidos palmitico 5,8:32,8; esteárico 38,3:35,5; oléico 42,8:29,6; araquídico 4,8:1,0; linoléico $8,3: 1,1 \%$,respectivamente (Vasconcelos et al., 1975), apresentando-se portanto a manteiga de cacau, mais saturada.

Berbert (1981), estudando a composição e características físicas das gorduras do cupuaçu ( $T$. grandiflorum $L$.) e do cacau tigre (Theobroma bicolor L.) e comparando-as com a manteiga de cacau, verificou que as manteigas das duas espécies, ainda que possuam ponto de fusão 
respectivamente igual e superior à manteiga de cacau $\left(32^{\circ} \mathrm{C}\right.$ e $\left.35^{\circ} \mathrm{C}\right)$, são bem mais macias que esta última, o que as torna aparentemente inadequadas para o fabrico de chocolate em barra, mas thes confere possibilidades de utilização como matéria prima na indústria de margarina. A resistência à fusão apresentada pela gordura do cupuaçu é mais baixa que a do cacau e a do cacau tigre é superior a ambas. As gorduras do cupuaçu e do cacau tigre apresentam teores mais altos de ácidos graxos insaturados, apresentando-se pastosas à temperatura ambiente.

Chaiseri et al. (1989), estudaram o comportamento térmico e composição das gorduras de $T$. angustifolia, $T$. bicolor (da Costa Rica e do Brasil), T. gileri, T.grandiflorum e T. mammosa, avaliando-os em comparação com a manteiga de cacau. Com exceção de $T$. gileri, as sementes das outras espécies apresentaram altos teores de gordura o que poderia apresentar algum significado comercial. A gordura de T. bicolor da Costa Rica apresentou a maior similaridade com a manteiga de cacau, tanto em composição como em características térmicas, com a desvantagem de ter apresentado alto teor de gordura sólida (SFC) a temperaturas acima de $35^{\circ} \mathrm{C}$, provavelmente como resultado de um alto teor do triacilglicerol SOS, o que pode causar um indesejável caráter à degustação. As gorduras, com exceção de $T$. bicolor da Costa Rica, exibiram SFC mais baixos que aqueles de $T$. cacao a temperatura ambiente $\left(20-25^{\circ} \mathrm{C}\right)$, como resultado de altos teores de ácidos oléico e linoléico. $O$ ponto de fusão de $T$. bicolor da Costa Rica foi semelhante ao da manteiga de cacau. A diferença entre T.bicolor da Costa Rica e do Brasil é que esta teve mais altos teores de componentes insaturados, resultando em uma manteiga mais macia. Esse alto grau de insaturação de $T$. bicolor do Brasil poderia ser resultado de diferenças varietais ou de temperatura nas regiões de produção. 


\subsection{Polimorfismo da manteiga de cacau}

A manteiga de cacau como muitas gorduras é polimórfica, ou seja, pode solidificar em numerosas formas cristalinas distintas, dependendo das condições de resfriamento. Cada forma ou polimorfo tem sua própria faixa de fusão em vez de um ponto de fusão preciso, devido à mistura de triglicerídios que a compõem. Todas as formas, com exceção daquela de mais alto ponto de fusão, são relativamente instáveis. A estabilidade aumenta das formas de ponto de fusão mais baixo para aquelas de ponto de fusão mais alto (Johnston, 1972). O quadro é complicado pelo fato da manteiga de cacau não ser uma mistura única de triglicerídios, podendo, como foi mencionado, apresentar variações em sua composição, dependendo da origem do cacau comercial e do processo utilizado para a extração. Segundo Johnston (1972), cada polimorfo exibe uma faixa de pontos de fusão finais, de amostra para amostra. Os padrões de fusão da manteiga de cacau e do chocolate são claramente muito dependentes dos polimorfos presentes e suas proporções (Johnston, 1972). Todos os resultados sugerem que a estabilidade dos cristais na manteiga de cacau, não depende somente da estrutura cristalina interna mas também da composição trigliceridica dos cristais (Arohnime et al., 1988).

Para Minnifie (1989), há 4 formas polimórficas cristalinas principais, com as seguintes propriedades: a) Forma $\gamma$ - produzida pelo resfriamento muito rápido da gordura líquida. Seu ponto de fusão é aproximadamente $17^{\circ} \mathrm{C}$. É muito instável e se transforma rapidamente, mesmo a baixas temperaturas na forma $\alpha$; b) forma $\alpha$ - apresenta ponto de fusão entre 21 a $24^{\circ} \mathrm{C}$; c) forma $\beta^{\prime}$ - a forma $\alpha$ se transforma à temperatura ambiente na forma $\beta^{\prime}$ (ponto de fusão entre 27 e $29^{\circ} \mathrm{C}$; d) forma $\beta$ - a forma $\beta^{c}$ eventualmente se transforma na forma $\beta$, a qual é estável e tem um ponto de fusão de 34 a $35^{\circ} \mathrm{C}$. A estabilidade das diferentes formas aumenta da forma $\gamma$ para a $\beta$ e em todos os processos da fabricação do chocolate o objetivo é 
manter a manteiga de cacau e o chocolate na forma mais estável. Falha em conseguir isso resultará má qualidade do produto final.

Vários pesquisadores (Lovegren et al., 1976; Dimick e Manning, 1987), têm mencionado outros polimorfos, mas segundo Minnifie (1989), de um ponto de vista prático os quatro mencionados são os mais importantes.

\subsection{Substitutos da manteiga de cacau}

A demanda por cacau na década de 1970 foi influenciada pela crescente competição de substitutos de cacau. Os altos preços de cacau nos anos anteriores, estimularam os chocolateiros a procurar produtos alternativos como uma forma de manter custos baixos e permanecer competitivos com as indústrias do ramo de alimentos afins. Como consequência observou-se uma tendência a se usar menos cacau no produto final. Essa decrescente utilização de cacau na elaboração do chocolate indica uma substituição do cacau por sucedâneos, dos quais diversas linhas têm sido desenvolvidas (Menezes e Barroco, 1986).

Segundo Gerrit (1994), os substitutos da manteiga de cacau existem desde há muito tempo. Sua introdução data da grande guerra, quando não havia suprimento de manteiga de cacau. No presente, contudo, a mais importante razão para seu uso é que alguns fabricantes de chocolate preferem substituir a manteiga de cacau, relativamente cara, pelas gorduras substitutas, mais baratas. Aos fabricantes de chocolate da União Européia em geral, não é permitido chamar de chocolate os produtos que contenham substitutos da manteiga de cacau, isso não se aplicando à Dinamarca, Irlanda e Reino Unido, que permitem o uso de gorduras vegetais outras que não a manteiga de cacau até um limite máximo de $5 \%$ do peso total do chocolate.

Por muitos anos, pesquisadores trabalharam para produzir um substituto satisfatório que pudesse ser usado para substituir pelo menos em parte a manteiga de cacau em chocolates finos, ou substituí-la totalmente em 
chocolates para cobertura (Minnifie, 1989). Para esse autor, os sucedâneos da manteiga de cacau podem ser classificados em:

1) Gorduras equivalentes à manteiga de cacau (CBE) - uma gordura equivalente é aquela que apresenta todas as propriedades físicas e químicas da manteiga de cacau mas tem seus gliceridios constituintes derivados de outras fontes que não a semente do cacaueiro. Ela não necessita ter as características de "flavour" da manteiga de cacau. O primeiro desenvolvimento nesse campo foi a invenção da Coberina pela Unilever Co., trabalhando em conjunto com uma companhia lider na industria de chocolate. Foi coberta por patente que descreveu o fracionamento do óleo de palma. A gordura tem uma composição glicerídica quase idêntica à manteiga de cacau e pode portanto ser misturada com ela em qualquer proporção e usada na fabricação do chocolate sem qualquer alteração na fusão. A opinião legal em numerosos países, é que essa gordura não deveria ser utilizada no chocolate descrito como tal.

2) Gorduras substitutas da manteiga de cacau (CBS): são gorduras que não têm nenhuma semelhança com a manteiga de cacau, mas podem ser usadas com algum êxito quando misturadas em pequenas quantidades com manteiga de cacau ou chocolate. As CBSs podem ser classificadas em 2 grupos: a) CBS láuricos: trata-se de uma faixa de gorduras com diferentes propriedades físicas, mas todas apresentando configurações triglicerídicas que as tornam incompativeis com a manteiga de cacau. São glicerídios de ácidos graxos de cadeia curta. A maioria dessas gorduras é baseada em óleo de semente de palma; b) CBSs não láuricos: essas gorduras consistem de frações obtidas de óleos hidrogenados - usualmente soja, semente de algodão, amendoim, milho. Esses óleos são hidrogenados seletivamente com a formação de ácidos graxos trans, os quais aumentam a fase sólida da gordura. Seus comprimentos de cadeia e pesos são semelhantes aos da manteiga de cacau e por isso, CBSs não láuricos tolerarão manteiga de cacau em mistura de 20 a $25 \%$. 


\subsection{Outras gorduras associadas à manteiga de cacau}

Em termos de conteúdo de gordura a manteiga de cacau representa o constituinte principal do cotilédone (55\% aproximadamente da matéria seca), enquanto a testa e o germe contém somente $3-5 \%$ de gordura calculada com base na matéria seca. Em comparação com a manteiga de cacau pura, algumas diferenças foram observadas na composição de ácidos graxos, como a presença de ácidos graxos de cadeia curta, a presença de teores mais altos de ácidos láurico e mirístico, teores mais baixos de ácido esteárico e altos teores de ácidos insaturados de cadeia longa. A diferença na composição de ácidos graxos se reflete na composição triglicerídica: em manteiga de cacau pura, praticamente nenhum triglicerídio de cadeia curta está presente, enquanto gordura de testa mostra uma distribuição mais complicada, com a fração monoinsaturada (POP, POS, SOS ) que representa cerca de $60 \%$ dos triglicerídios na manteiga de cacau, sendo somente de $35 \%$ na gordura de testa. Contudo, a relação SOS:POP está dentro dos limites de 0,8 a 1,15, a qual tem sido considerada típica para a manteiga de cacau. A composição de esteróis na gordura de testa, é também um pouco diferente da encontrada na manteiga de cacau com respeito à presença de lanosterol, níveis relativos mais altos de $\beta$-sitosterol e relação estigmasterol:campesterol mais baixa. (Bracco et al., 1976). Valores baixos de colesterol foram encontrados em ambas. A estabilidade da manteiga de cacau e gordura de testa à rancificação oxidativa a $100^{\circ} \mathrm{C}$, foi a mesma (10,5 horas) (El-Saied et al., 1981). Na opinião de Minnifie (1989), a gordura de testa é muito mole, frequentemente com alto teor de

ácidos graxos livres, pobre em "flavour" e considerada' por alguns, como adulterante da manteiga de cacau. 


\subsection{Influência do processamento na qualidade da manteiga de cacau}

Não foi encontrada diferença significativa no teor de gordura de cotilédones fermentados e não fermentados. Há indicação de que há um ligeiro aumento no teor, nos primeiros quatro dias de fermentação, seguido por um declínio, resultando em pequena perda líquida Chatt (1953). Na determinação do teor de gordura em amêndoas de cacau antes e depois da torrefação, Dittmar e Raimann (1956) verificaram sempre uma diferença sensível de mais de $1 \%$ de manteiga de cacau.

Clapperton (1992), é de opinião que para as análises seria mais recomendado evitar a fermentação mas os fabricantes de chocolate querem que os resultados obtidos sejam tornados relevantes pela comparação direta com amêndoas fermentadas e secas do mesmo genótipo.

Esteves et al. (1991), encontraram diferenças significativas nos teores de manteiga de cacau, bem como em sua composição, com o método de extração utilizado.

Com respeito ao armazenamento, o desenvolvimento de fungos nas amêndoas de cacau sob condições ambientais úmidas tem marcada atividade lipolítica, resultando na alteração na composição de ácidos graxos livres, que além disso têm seu teor aumentado. Os teores de ácidos esteárico e palmítico aumentaram enquanto os teores de oléico e linoléico decresceram. (Kavanagh et al., 1970).

\subsection{Produção in vitro de lipídios da semente de cacau}

A manteiga de cacau é a mais cara dentre as gorduras comestíveis. $O$ suprimento de amêndoas de cacau é instável devido a razões climáticas, econômicas e políticas o que a seu turno causam elevações ainda mais significativas nos preços. Os altos preços e o suprimento instável têm forçado os fabricantes de chocolate a examinar formas de suplementar a 
manteiga de cacau com outros tipos de gorduras sem alterar a qualidade do produto final. Contudo, há problemas para essa substituição, tais como padrões de fusão inadequados, altos preços ou argumentos legais em muitos países, de que essas gorduras não podem ser usadas em produtos descritos como chocolate. Por esses motivos, começou a ser estudada a possibilidade de se usar cultura de tecidos para a produção de produtos do tipo da manteiga de cacau (Wen et al., 1984).

Por representarem o produto mais valioso e mais bem definido quimicamente, os lipídios da semente do cacaueiro têm sido monitorados como produto em culturas de embriões assexuais, mas ainda que culturas de células produzam ácidos graxos associados com a manteiga de cacau, seu teor e proporções não se assemelham àqueles encontrados dos lipídios de reserva das sementes maduras. Claramente, a produção in vitro da manteiga de cacau, requeriria uma compreensão mais aprofundada da regulação metabólica da biossíntese de lipídios (Janick, 1986).

Pence et al. (1981), trabalhando com embriões assexuais de cacau cultivados in vitro, observaram alterações na composição dos ácidos graxos similares àquelas que ocorrem em embriões zigóticos durante maturação normal, que foram estimuladas conforme a concentração de sacarose no meio foi aumentada até um ótimo de $27 \%$ de sacarose $(p / v)$. Foi registrada uma mudança na composição de ácidos graxos, de polinsaturados para saturados e monoinsaturados, caracterizada por aumento nos teores de ácido esteárico e oléico e um decréscimo nos teores de ácido linoléico e linolênico.

Embriões assexuais de cacau foram desenvolvidos por 40-50 dias em meio com concentração de sacarose variando de 3 a $27 \%$ e temperaturas aumentando de 3 em 3 graus, de 10 a $35^{\circ} \mathrm{C}$, tendo sido observado máximo crescimento a $29^{\circ} \mathrm{C}$, enquanto máximo acúmulo de lipídios e ácidos graxos 
ocorreu a $26^{\circ} \mathrm{C}$, temperatura em que ocorreu a composição mais semelhante àquela da manteiga de cacau (Wright et al., 1983).

Figueira e Janick (1994), observaram que embriões somáticos não atingiram a maturidade caracterizada pelo teor de ácidos graxos de $50 \%$ com base na matéria seca. Os níveis mais altos corresponderam a $39 \%$, mas devido a variabilidade, a mais alta média para qualquer experimento individual foi de $25 \%$ de ácidos graxos. Os autores consideram que os fatores limitantes são desconhecidos e que a utilização de embriōes somáticos para produção de metabólitos requer o desenvolvimento de protocolos para a indução de completa maturidade dos cotiledones in vitro, havendo necessidade de pesquisa sobre a fisiologia da morfogênese de embriões somáticos. 


\section{MATERIAL E MÉTODOS}

\subsection{Local}

Os frutos estudados foram provenientes da coleção de germoplasma da Estação Experimental do Instituto Agronômico, localizada em Pariquera-Açú, Estado de São Paulo, a 24 43' S, 47 53' W, 25 m de altitude, plantada em 1975, em espaçamento de 3,5 x $3 \mathrm{~m}$. A Estação Experimental possue área correspondente a 248 ha e está situada no litoral sul de São Paulo, região do Vale do Ribeira, município de Pariquera-Açú, à margem direita do rio Jacupiranga, sendo cortada pela rodovia Régis Bittencourt (BR 116), no km 460.

\subsection{Clima}

A área enquadra-se na faixa climática Cf de Köppen, definida como clima tropical quente e úmido sem estação seca, com chuva anual média de $1587 \mathrm{~mm}$ (média mensal superior a $50 \mathrm{~mm}$ ), evapotranspiração potencial de $11140 \mathrm{~mm}$, excedente de $447 \mathrm{~mm}$ e deficiência hídrica nula (Sakai e Lepsch, 1984). A temperatura média do mês mais quente é de $25,2^{\circ} \mathrm{C}$ e a média do mês mais frio é de $17,9^{\circ} \mathrm{C}^{3}$

\footnotetext{
${ }^{3}$ Dados fornecidos pela Seção de Climatologia Agrícola do Instituto Agronômico (IAC). Campinas, 1994.
} 


\subsection{Geologia}

As colinas da Estação Experimental situam-se em área de formação Pariquera-Açú, da época pleistocênica, composta por sedimentos areno-argilosos intercalados na sua base por conglomerados quartzílicos. As várzeas são compostas de sedimentos holocênicos, variavelmente argilosos, areno-argilosos ou turfosos. Existem em algumas áreas entre as colinas e a várzea, afloramento de regolito derivado de migmatitos do pré-cambriano sob o conglomerado basal dos sedimentos Pariquera-Açú (Morgental et al., 1974).

\subsection{Solo}

O solo do campo VR 13, do qual os frutos foram provenientes, foi classificado por Sakai e Lepsch (1984), como um Latossolo Amarelo Álico A moderado textura argilosa, unidade Pariquera I ( $\mathrm{Pq} \mathrm{I}$ ), pelo sistema americano um Ultic Haplortox (atualmente Ultic Hapludox). A análise química de amostras do mesmo tipo de solo em condições de cultivo e mata natural, é apresentada na Tabela 4 (adaptada de Sakai e Lepsch, 1984, por Abreu Jr., 1995).

Tabela 4 - Análise química do horizonte A e B de um Latossolo Amarelo Álico A moderado textura argilosa, em condições de cultivo e de mata natural (adaptado de Sakai e Lepsch, 1984, por Abreu Jr., 1995).

\begin{tabular}{|c|c|c|c|c|c|c|c|c|c|c|c|c|}
\hline \multirow[t]{2}{*}{ Horizonte } & \multirow{2}{*}{$\begin{array}{l}\mathrm{pH} \\
\text { água }\end{array}$} & \multirow{2}{*}{$\begin{array}{l}\text { P resina } \\
\mu \mathrm{g} \mathrm{cm}^{-3}\end{array}$} & \multirow{2}{*}{$\begin{array}{c}\mathrm{C} \\
\mathrm{g} \mathrm{kg}^{-1}\end{array}$} & $\mathrm{Ca}$ & Mg & K & $\mathrm{H}$ & Al & SB & СТC & \multirow{2}{*}{$\begin{array}{c}V \\
\cdots\end{array}$} & \multirow[t]{2}{*}{ m } \\
\hline & & & & & & c-a & nol & & & & & \\
\hline$A^{1}(0-20 \mathrm{~cm})$ & 5,0 & -- & 21 & 1,8 & 0,27 & 0,15 & 4,0 & 1,1 & 2,22 & 7,32 & 30 & 33 \\
\hline $\mathrm{B}^{1}(60-80 \mathrm{~cm})$ & 4,5 & --- & 5 & 0,4 & 0,11 & 0,03 & 1,7 & 3,0 & 0,54 & 5,24 & 10 & 85 \\
\hline$A^{2}(0-20 \mathrm{~cm})$ & 3,6 & 9,0 & 40 & 0,1 & 0,3 & 0,01 & & & 0,41 & $9,0 \cdot 1$ & 5 & -- \\
\hline
\end{tabular}

1 - área de cultivo

2 - área de mata natural 


\subsection{Vegetação}

A vegetação original é a floresta tropical perenifólia, que ainda é observada em algumas áreas da Estação Experimental. As espécies mais comuns e que provavelmente compõem o sombreamento da área experimental, são o angelim, arapaçu, araribá (Centrolobium spp), cabreúva (Myrocarpus frondosus), canela-sassafrás (Ocotea pretiosa), canelina (Ocotea pulchella), guapiruvu (Schizolobium paraybum), guatambu (Aspidosperma sp), jequitibá (Cariniana legalis), manacá (Brunfelsia hopeana), manacá-da-serra (Tiboreclima sp), palmito branco (Euterpe edulis), pau-ferro (Caesalpinea ferrea), peroba (Aspidosperma polyneuron), angelim-de-espinho (Andira spinulosa), angelim-rosa (Platycyamus regnelli), angelim-araroba (Valaireopis araroba) (Sakai e Lepsch, 1984)

\subsection{Material vegetal}

Foram estudados os seguintes genótipos:

IAC1 - selecionado pelo Instituto Agronômico, Campinas, São Paulo, Brasil, em progênie de UF677, de polinização livre.

ICS95 - Imperial College Selection - seleção realizada pelo Imperial College de Trinidad. O genótipo estudado pertence ao grupo Trinitário.

IMC67 - Iquitos Mixed Calabacillo - proveniente de árvore coletada por F.J. Pound em 1938, em expedição ao rio Parinari em lquitos, Peru.

P7 - proveniente de árvore originalmente selecionada por F.J. Pound, em 1943, no rio Nanay, Peru.

SCA6 e SCA12 - genótipos originalmente coletados por F.J. Pound em 1937, selecionados pela resistência ao fungo Crinipellis perniciosa (Stahel) Singer. 
UF613, UF667 e UF668 - Seleções realizadas pela "United Fruit Co.", em Limón, Costa Rica. Os genótipos estudados pertencem ao grupo Trinitário.

UF29 - seleção da "United Fruit Co.", em material de origem equatoriana.

Os genótipos SCA6, SCA12, ICS95, IMC67, UF613, UF667 e UF668, foram introduzidos no Estado de São Paulo, entre os anos de 1955 e 1960, a partir de material proveniente do Posto Agropecuário do Ministério da Agricultura, Santarém, Pará, enquanto P7 e UF29, foram introduzidos respectivamente em 1964 e 1970, a partir de material proveniente do IICA, Turrialba, Costa Rica.

A colheita dos frutos maduros foi realizada entre os meses de maio de 1995 (IAC1, IMC67, P7, SCA6, SCA12, UF29, UF613, UF667, UF668) e junho de 1995 (ICS 95).

Na Figura 2, estão apresentados os valores médios mensais de temperaturas médias, máximas e mínimas, precipitação pluviométrica e insolação, da região de Pariquera-Áçú (médias correspondentes ao periodo de 1961 a 1990) e na Tabela 5, estão apresentados os mesmos valores, referentes aos 4 meses anteriores à colheita dos frutos. Foram consideradas as condições climáticas desse período, uma vez que parte substancial da manteiga de cacau é sintetizada a partir de 120 dias pós-polinização (Lehrian e Keeney, 1980). 
Figura 2 - Valores médios mensais de temperaturas médias, máximas e mínimas, precipitação pluviométrica e insolação, da região de Pariquera-Açú (médias correspondentes ao período de 1961 a 1990) (Departamento Nacional de Meteorologia, 1992).

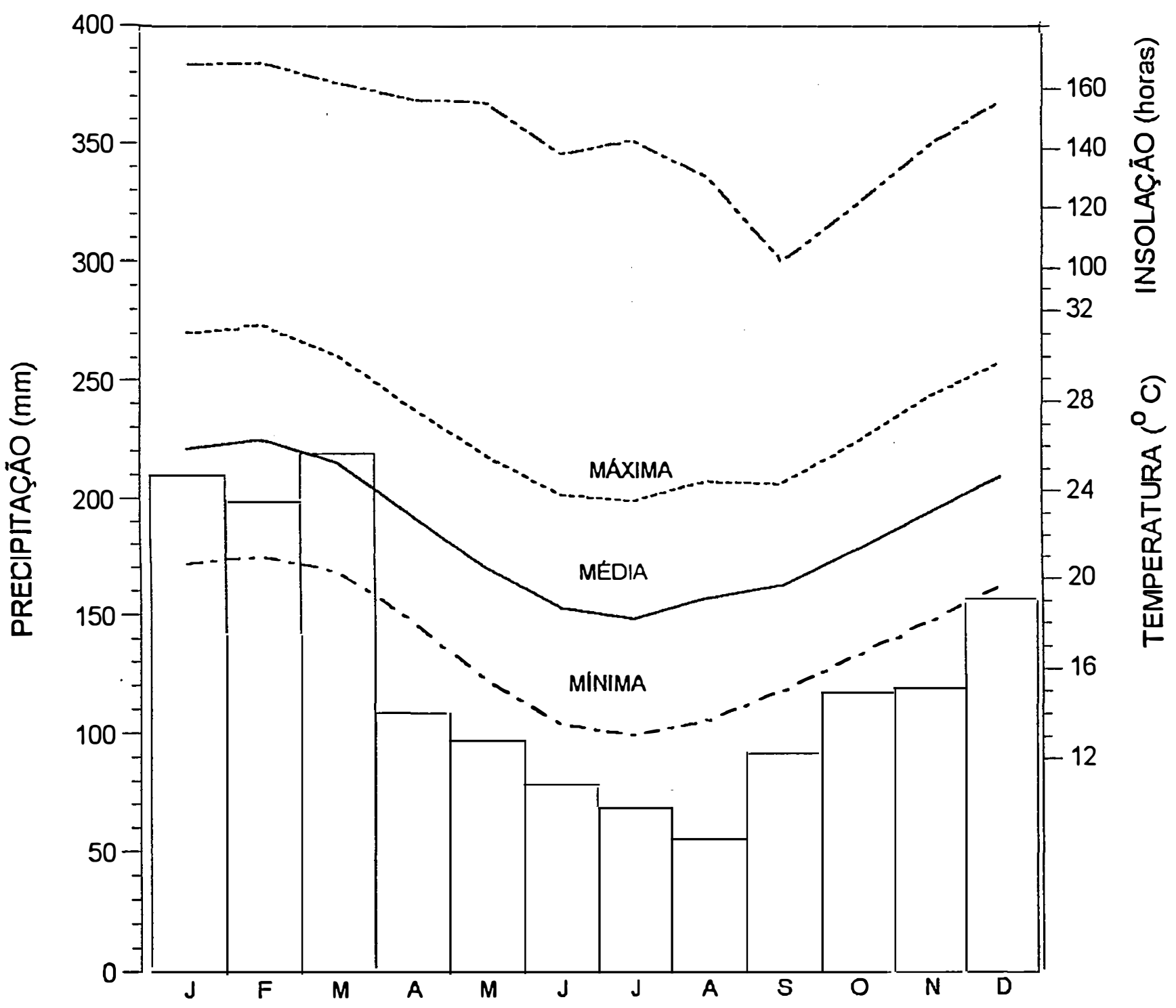


Tabela 5 - Valores médios mensais de temperaturas médias (TM), máximas (TMAX) e mínimas (TMIN), precipitação pluviométrica (PPT) e insolação (INS) da região de Pariquera-Açú referentes aos 4 meses anteriores à colheita dos frutos.

\begin{tabular}{|c|c|c|c|c|c|}
\hline Meses & $\begin{array}{c}\text { TM } \\
\left.\text { ( }^{\circ} \mathrm{C}\right)\end{array}$ & $\begin{array}{l}\text { TMIN } \\
\left({ }^{\circ} \mathrm{C}\right)\end{array}$ & $\begin{array}{l}\text { TMAX } \\
\left({ }^{\circ} \mathrm{C}\right)\end{array}$ & $\begin{array}{c}\text { PPT } \\
(\mathbf{m m})\end{array}$ & $\begin{array}{c}\text { INS } \\
\text { (horas) }\end{array}$ \\
\hline JAN & 27,3 & 22,3 & 32,3 & 314,0 & 117,8 \\
\hline FEV & 26,0 & 21,5 & 30,5 & 226,0 & 109,2 \\
\hline MAR & 24,9 & 19,6 & 30,1 & 349,0 & 142,6 \\
\hline ABR & 22,9 & 17,2 & 28,5 & 101,0 & 171,0 \\
\hline MÉDIA & 25,3 & 20,2 & 30,4 & 247,5 & 135,2 \\
\hline
\end{tabular}

FONTE: Seção de Climatologia Agrícola do Instituto Agronômico (IAC).

\subsection{Amostragem}

Para a análise das características dos frutos e da gordura foram sorteadas 6 árvores por clone e de cada uma foram colhidos 5 frutos de polinização aberta. As sementes foram coletadas, despolpadas, tiveram a testa removida e foram submetidas à secagem em estufa a $50^{\circ} \mathrm{C}$, por 3 dias, sendo então estocadas em sacos de papel, em condições ambientes até serem analisadas. Cada amostra foi constituida das sementes secas de um fruto, tendo-se obtido portanto 300 amostras. Foram determinados os teores de gordura por Ressonância Nuclear Magnética para as 300 amostras. Para a determinação dos teores de gordura por Soxhlet, foram sorteadas 6 amostras por clone, totalizando 60 amostras. Para as demais análises foram sorteadas 4 amostras por clone, com exceção da determinação dos teores de triacilgliceróis, que foram determinados em 2 amostras por clone. Para a análise das características das sementes foram colhidos 20 frutos por clone, de cada um dos quais foram analisadas 10 sementes. 


\subsection{Caracterização de frutos e sementes}

Frutos e sementes foram caracterizados segundo metodologia recomendada por Enriquez e Soria (1967)

\subsection{Determinação de gordura}

\subsubsection{Teor de gordura}

O teor de gordura foi determinado através de dois métodos distintos:

3.9.1.1. Determinação do teor de gordura pelo método do Office International du Cacao et du Chocolat - OICC (1963)

As sementes sem testa, foram moídas em moedor de café. Foi pesada uma sub-amostra de $5 \mathrm{~g}$, que foi colocada em estufa a $110^{\circ} \mathrm{C}$ por 2 horas, sendo em seguida digerida com solução $4 \mathrm{~N} \mathrm{HCl}$, filtrada e lavada com água quente, até eliminação dos pigmentos. $O$ material digerido foi colocado em cartucho de Soxhlet, submetido à secagem em estufa a $110^{\circ} \mathrm{C}$ por 2 horas e à extração com éter de petróleo por 4 horas em conjunto extrator de Soxhlet. Foram realizadas duas determinações por amostra. Os resultados foram expressos com base na matéria seca. As determinações foram realizadas no laboratório do Almirante Centro de Estudos de Cacau, Itajuípe (BA).

3.9.1.2. Determinação do teor de gordura pelo método de Ressonância Nuclear Magnética - RNM

A determinação foi executada segundo o método do International Union of Pure and Applied Chemistry - IUPAC 1.123 (1987). As sementes 
foram moídas em liquidificador de copo blindado e então submetidas à secagem a $130^{\circ} \mathrm{C}$ por 2 horas. As determinações foram realizadas em equipamento Oxford 4000 NMR ANALYSER, em tubos de $40 \mathrm{ml}$, utilizando-se os seguintes parâmetros: RF Level - 150; AF Gain - 500; Gate Width - 1,5. Os resultados foram expressos com base na matéria seca. As determinações foram realizadas no laboratório do Centro de Química do Instituto de Tecnologia de Alimentos (ITAL), Campinas (SP).

\subsubsection{Análise de ácidos graxos}

A composição em ácidos graxos foi determinada por cromatografia gasosa capilar. Para o preparo da amostra, pesou-se $0,1 \mathrm{~g}$ de manteiga de cacau previamente fundida e adicionaram-se $4 \mathrm{ml}$ de $0,5 \mathrm{~N} \mathrm{NaOH}$ metanólico, mantendo-se sob refluxo por 15 minutos. Adicionaram-se $3 \mathrm{ml}$ de $\mathrm{BF}_{3}$ metanol e efetuou-se o refluxo por mais 5 minutos. Adicionaram-se $5 \mathrm{ml}$ de hexano e manteve-se o refluxo por mais 5 minutos. Após resfriamento da amostra foi adicionada solução saturada de $\mathrm{NaCl}$. Uma alíquota do sobrenadante foi transferida para tubo de $1 \mathrm{ml}$ cuja tampa foi selada. As análises foram realizadas em cromatógrafo a gás Hewlett Packard 5890, equipado com detector de chama ionizante, integrador 3390 II, 7673A "autosampler" e coluna capilar de sílica fundida $25 \mathrm{~m} \times 0,32 \mathrm{~mm}$ SP2340 (SUPELCO Bellefonte, PA, EUA). Condições de cromatografia: Temperatura de injeção $-220^{\circ} \mathrm{C}$; volume de injeção - 0,5 $\mu$; gás carreador - hélio; velocidade linear do gás carreador - $30 \mathrm{~cm} \mathrm{seg}^{-1}$; relação de Split - 60:1; detector - FID a $220^{\circ} \mathrm{C}$. As determinações foram realizadas no laboratório do Almirante Centro de Estudos de Cacau, Itajuípe (BA). 


\subsubsection{Análise de triacilgliceróis}

A determinação da composição de ácidos graxos livres, esteróis, mono-, di- e triacilgliceróis, foi executada por Cromatografia Gasosa Capilar. Foram pesados $10 \mathrm{mg}$ de manteiga de cacau previamente fundida e foram adicionados $100 \mu \mathrm{l}$ da solução padrão (10 mg de cada um dos compostos: ácido mirístico; 1-monomiristoilglicerol; 1,3 dimiristina; trimiristina), $100 \mu \mathrm{lde}$ piridina e $100 \mu \mathrm{l}$ BSTFA - bis(trimetil)silil-trifluoroacetamida. A solução foi mantida por 15 minutos à temperatura ambiente, após o que acrescentou-se 1 $\mathrm{ml}$ de hexano no frasco, que foi selado. Injetou-se no cromatógrafo a gás $1 \mu \mathrm{l}$ da amostra. As análises foram realizadas em cromatógrafo à gás, Hewlett Packard 5890, equipado com detector de chama ionizante, integrador 3390 II, 7673A autosampler e coluna capilar de sílica fundida, High Temperature Polyimide-Clad Fused Silica Capillary Column (Quadrex Co, New Haven, Connecticut, EUA). Condições de cromatografia: temperatura de injeção $150^{\circ} \mathrm{C}$; volume de injeção - 1,0 $\mu$; gás carreador - hélio; velocidade linear do gás carreador - $20 \mathrm{~cm} \mathrm{seg}^{-1}$; ar sintético - $400 \mathrm{~cm} \mathrm{seg}^{-1}$; hidrogênio - $30 \mathrm{~cm} \mathrm{seg}$ 1; relação de Split: $90: 1$; detector - FID à $380^{\circ} \mathrm{C}$; injetor - $370^{\circ} \mathrm{C}$. Os triacilgliceróis foram identificados pelo tempo de retenção e comparação dos dados cromatográficos com cromatogramas obtidos por Geeraert e Sandra (1987). As determinações foram realizadas no laboratório do Almirante Centro de Estudos de Cacau.

\subsubsection{Análise de dureza (resistência à fusão)}

A dureza da gordura foi determinada por calorimetria diferencial de varredura (DSC), segundo protocolo adotado pela empresa Almirante Centro de Estudos de Cacau. Amostras de manteiga de cacau de aproximadamente 2 a $5 \mathrm{mg}$, após terem sido colocadas em recipiente apropriado e lacrado, foram submetidas a um programa de temperatura 
utilizado pelo laboratório do Almirante Centro de Estudos de Cacau. Utilizou-se calorímetro diferencial da Perkin-Elmer, modelo DSC-7, acoplado à impressora. A corrida de cada amostra iniciou-se a $0^{\circ} \mathrm{C}$, sendo a temperatura elevada de $2,5^{\circ} \mathrm{C}$ por minuto, até a fusão total da manteiga. Os gráficos obtidos das curvas de fusão foram divididos em duas partes: $0-16^{\circ} \mathrm{C}$ e acima de $16^{\circ} \mathrm{C}$. Foram determinadas as porcentagens das amostras que permaneceram sólidas até estas atingirem a temperatura de $16^{\circ} \mathrm{C}$. As determinações foram realizadas no laboratório do Almirante Centro de Estudos de Cacau.

\subsubsection{Determinação do ponto de fusão}

O ponto de fusão foi determinado pelo método de capilar aberto, descrito por British Standards Methods for Analysis of Oils and Fats (1958). Foram tomados $10 \mathrm{~mm}$ de manteiga de cacau fundida, dentro de um tubo capilar de parede delgada e diâmetro interno de $1 \mathrm{~mm}$. $O$ tubo contendo a gordura foi colocado em refrigerador, em temperatura de 4 a $10^{\circ} \mathrm{C}$, por aproximadamente 16 horas. 0 tubo foi preso a um termômetro de precisão. 0 conjunto constituido pelo tubo capilar e o termômetro foi imerso em copo contendo $300 \mathrm{ml}$ de água destilada fria. A determinação teve início com a água entre 8 a $10^{\circ} \mathrm{C}$ e aplicou-se calor de forma a aumentar a temperatura da água de $0,5^{\circ} \mathrm{C}$ por minuto, agitando-se lentamente a água do banho. Foi tomado como ponto de fusão, a temperatura na qual a gordura se tornou transparente. As determinações foram realizadas na SETEA - Seção de Tecnologia e Engenharia Agrícola (CEPLAC), Itabuna (BA).

\subsection{Análise estatística}

Foi realizada a análise de variância dos dados obtidos, testandose diferenças entre médias pelo teste de Tukey a $5 \%$ de probabilidade. Análises de correlações entre os diferentes parâmetros em estudo foram 
efetuadas pelo método de Pearson (Steel e Torrie, 1980) a 5, 1 e $0,1 \%$ de probabilidade. 


\section{RESULTADOS E DISCUSSÃO}

\subsection{Características dos frutos}

A análise estatística das características dos frutos, bem como dos teores de gordura pelo método RNM, para os clones estudados mostrou efeitos significativos para todas as características analisadas (Tabela 6).

As características físicas dos frutos, bem como os teores de gordura pelo método RNM, estão expressos na Tabela 7. Os valores de comprimento e diâmetro dos frutos, estão coerentes com aqueles apresentados no Catálogo de Cultivares de Cacau (Enriquez e Soria, 1967). No entanto, a espessura da casca foi maior para todos os clones estudados, com exceção de UF 667, o que poderia ser atribuído às condições climáticas locais, em relação às regiões tradicionais de cultivo.

Com respeito ao clone IAC 1, não foi possivel comparar suas características locais com as regiões tradicionais de cultivo, por falta de referências na literatura.

É necessário esclarecer que os frutos estudados se desenvolveram durante o verão, em condições bastante favoráveis com respeito às temperaturas, precipitação pluviométrica e insolação (Figura 2).

Estudos de correlação (Tabela 8) mostram que os teores de gordura RNM correlacionaram positivamente com todas as variáveis analisadas, com exceção do número de sementes.

0 peso dos frutos está fortemente correlacionado com as condições climáticas do período de desenvolvimento. Lachenaud (1991), 
encontrou correlações positivas significativas entre peso de fruto e precipitação pluviométrica acumulada nos cinco e seis meses anteriores à colheita. Esse autor encontrou também correlação negativa significativa entre peso de frutos e época de colheita, com os frutos colhidos no início da safra maiores que aqueles produzidos posteriormente. Esse fato foi atribuído à competição entre frutos e possivelmente com lançamentos foliares. 


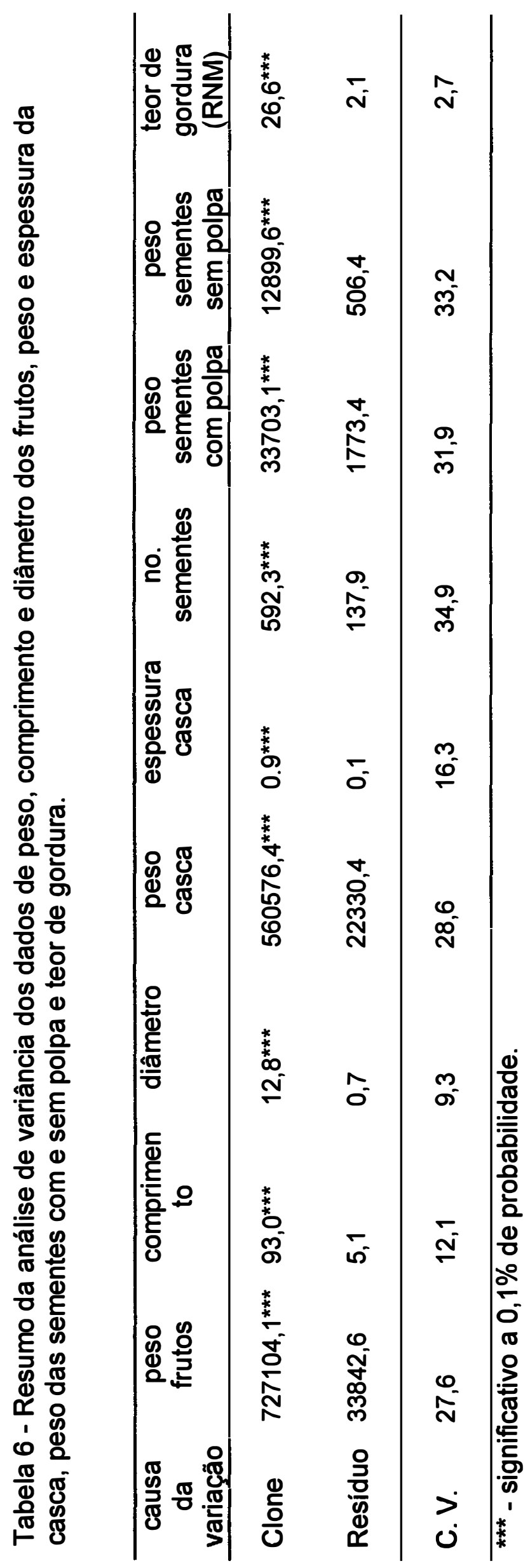




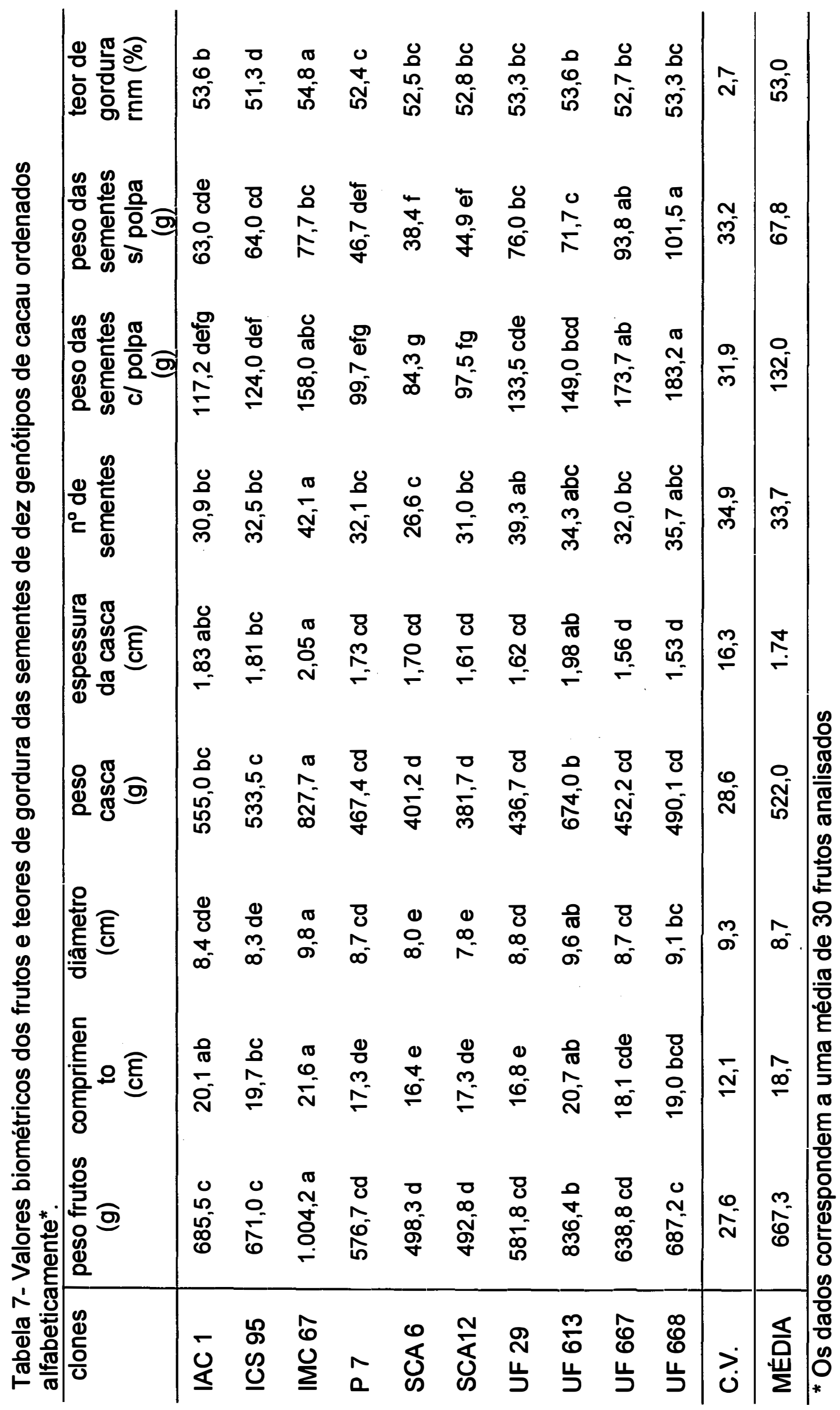




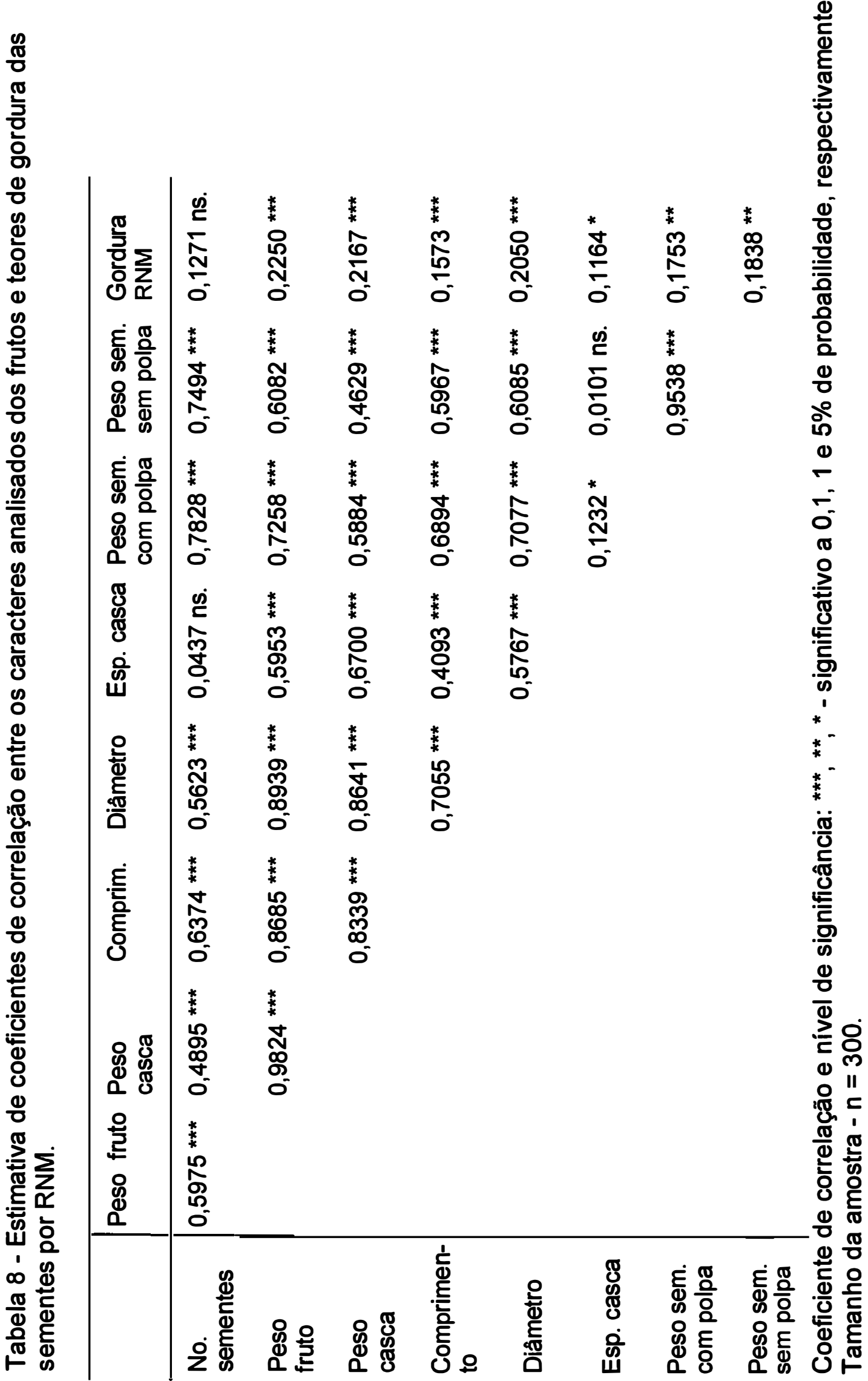




\subsection{Características das sementes}

A análise estatística do comprimento, largura e espessura das sementes, mostrou efeitos significativos para os três parâmetros (Tabela 9). Para todos os clones, os dados (Tabela 10) mostraram-se coerentes com aqueles expressos por Enriquez e Soria (1967), para as regiões tradicionais de cultivo.

$\mathrm{Na}$ Tabela 11 está expressa a análise de variância das demais características das sementes, tendo havido efeitos significativos para todas. Essas características estão expressas na tabela 12. Os valores de peso fresco e peso seco das sementes sem testa, bem como os teores de testa, estão coerentes com aqueles expressos por Enriquez e Soria (1967), com exceção do clone UF 667 cujas sementes apresentaram pesos fresco e seco mais baixos.

Foi observada correlação negativa altamente significativa entre peso seco das sementes sem testa e teores de testa (Tabela 13), correlação negativa entre gordura Soxhlet e teor de testa e correlação positiva entre peso seco das sementes sem testa e gordura Soxhlet.

O peso da semente seca é um parâmetro importante, uma vez que após a fermentação e secagem, as amêndoas devem possuir peso acima de 1 g para apresentar valor comercial. Para Wood (1985), as sementes desenvolvidas durante a estação seca são menores, tendo teores de testa mais altos e teores de gordura mais baixos.

Para o Estado de São Paulo, devido a estacionalidade do clima, é provável que se possam encontrar valores distintos para as características das sementes obtidas de frutos desenvolvidos em outras épocas do ano. 
Tabela 9 - Resumo da análise de variância do comprimento, largura e espessura das sementes dos clones estudados.

\begin{tabular}{llll}
\hline $\begin{array}{l}\text { causa da } \\
\text { variação }\end{array}$ & comprimento & largura & espessura \\
\hline Clone & $677,7^{* * *}$ & $394,1^{* * *}$ & $90,2^{* * *}$ \\
Resíduo & 4,2 & 1,2 & 1,4 \\
\hline C.V. & 8,5 & 8,7 & 12,8 \\
\hline$* * *$ & & \\
\hline
\end{tabular}


Tabela 10 - Valores biométricos das sementes de dez clones de cacau ordenados alfabeticamente*

\begin{tabular}{l|lll}
\hline clones & comprimento & largura & espessura \\
\hline IAC 1 & $2,5 \mathrm{~b}$ & $1,33 \mathrm{c}$ & $0,99 \mathrm{bc}$ \\
ICS 95 & $2,32 \mathrm{c}$ & $1,27 \mathrm{~d}$ & $0,97 \mathrm{c}$ \\
IMC 67 & $2,48 \mathrm{~b}$ & $1,17 \mathrm{e}$ & $0,85 \mathrm{~d}$ \\
P 7 & $2,19 \mathrm{de}$ & $1,13 \mathrm{e}$ & $0,85 \mathrm{~d}$ \\
SCA 6 & $2,06 \mathrm{f}$ & $1,05 \mathrm{f}$ & $0,82 \mathrm{~d}$ \\
SCA 12 & $2,14 \mathrm{ef}$ & $1,05 \mathrm{f}$ & $0,82 \mathrm{~d}$ \\
UF 29 & $2,24 \mathrm{~cd}$ & $1,27 \mathrm{~d}$ & $0,85 \mathrm{~d}$ \\
UF 613 & $2,53 \mathrm{~b}$ & $1,36 \mathrm{c}$ & $0,96 \mathrm{c}$ \\
UF 667 & $2,78 \mathrm{a}$ & $1,62 \mathrm{a}$ & $1,02 \mathrm{~b}$ \\
UF 668 & $2,82 \mathrm{a}$ & $1,57 \mathrm{~b}$ & $1,08 \mathrm{a}$ \\
\hline C.V. & 8,49 & 8,71 & 12,80 \\
\hline MÉDIA & 2,41 & 1,28 & 0,92 \\
\hline
\end{tabular}

* Os dados correspondem a uma média de 20 frutos analisados.

Médias seguidas da mesma letra na vertical não diferem entre si pelo teste de Tukey a $5 \%$ de probabilidade. 


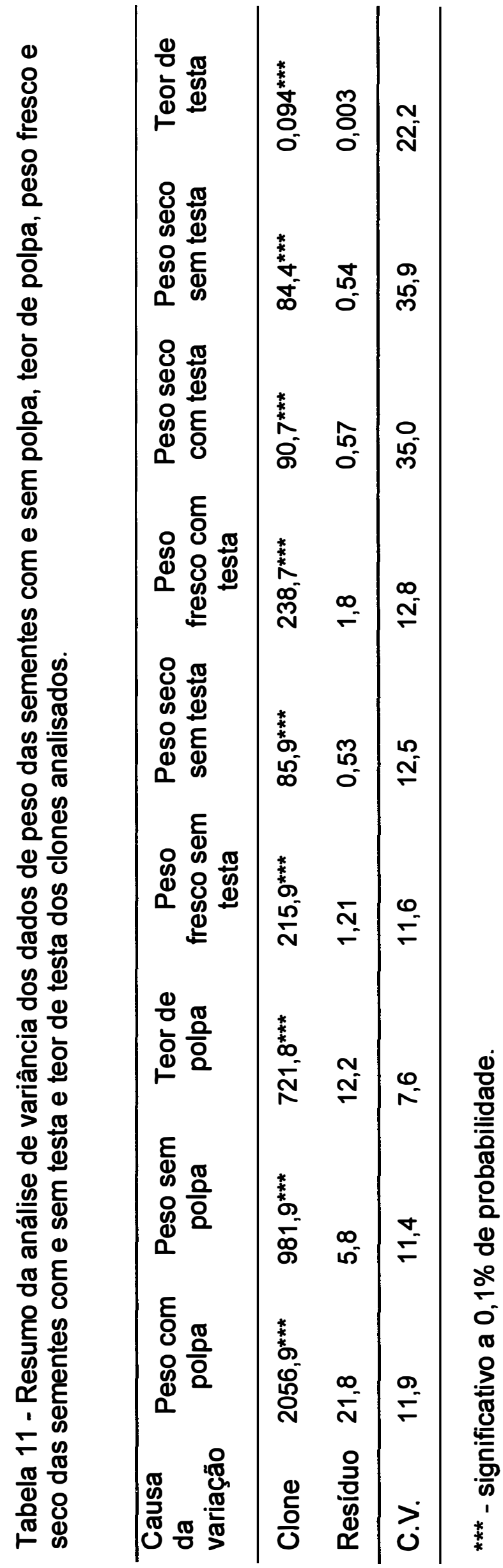




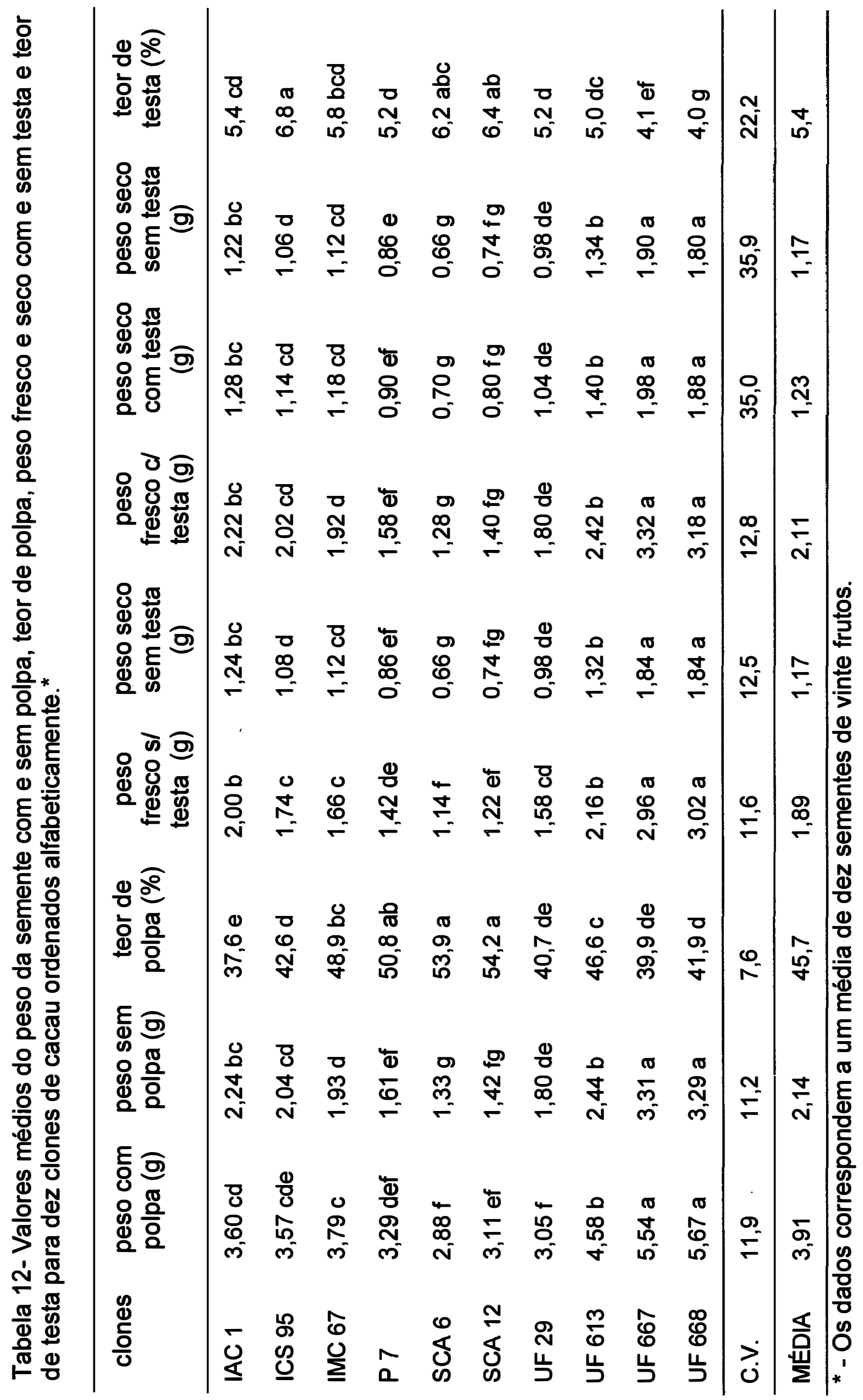


Tabela 13 - Estimativa de coeficientes de correlação entre os teores de gordura determinados por Soxhlet e RNM, peso seco das sementes sem testa e teor de testa.

\begin{tabular}{l|lll}
\hline & $\begin{array}{l}\text { Gordura } \\
\text { Soxhlet }\end{array}$ & $\begin{array}{l}\text { Peso seco } \\
\text { sementes s/ } \\
\text { testa }\end{array}$ & $\begin{array}{l}\text { Teor de testa } \\
(\%)\end{array}$ \\
\hline Gordura RNM & $0,7274 * * *$ & $0,2405 \mathrm{~ns}$ & $-0,2816^{*}$ \\
Gordura Soxhlet & & $0,3283^{*}$ & $-0,2765^{*}$ \\
Peso seco sementes s/ testa & & & $-0,8089^{* * *}$ \\
\hline
\end{tabular}

Coeficiente de correlação e nível de significância:

${ }^{* \star *},{ }^{* \star},{ }^{*}$ - significativo a $0,1,1$ e $5 \%$ de probabilidade, respectivamente.

Tamanho da amostra $-n=60$ 


\section{3. Épocas de produção}

Segundo Brilho e Tucci (1986), para as condições do Estado de São Paulo, os meses de maio e junho, correspondem ao ápice da produção anual de cacau, representando $24 \%$ do total da produção anual, cujo valor deve ser empregado para dimensionamento das instalações e equipamentos. No entanto, dados obtidos na Seção de Plantas Tropicais do Instituto Agronômico, mostram que existe variação nas épocas de produção entre os materiais clonais. As médias das produções de frutos colhidos mês a mês, para os clones estudados, durante o período de 1982 a 1994, estão apresentadas nas Figuras de 3 a 6. 


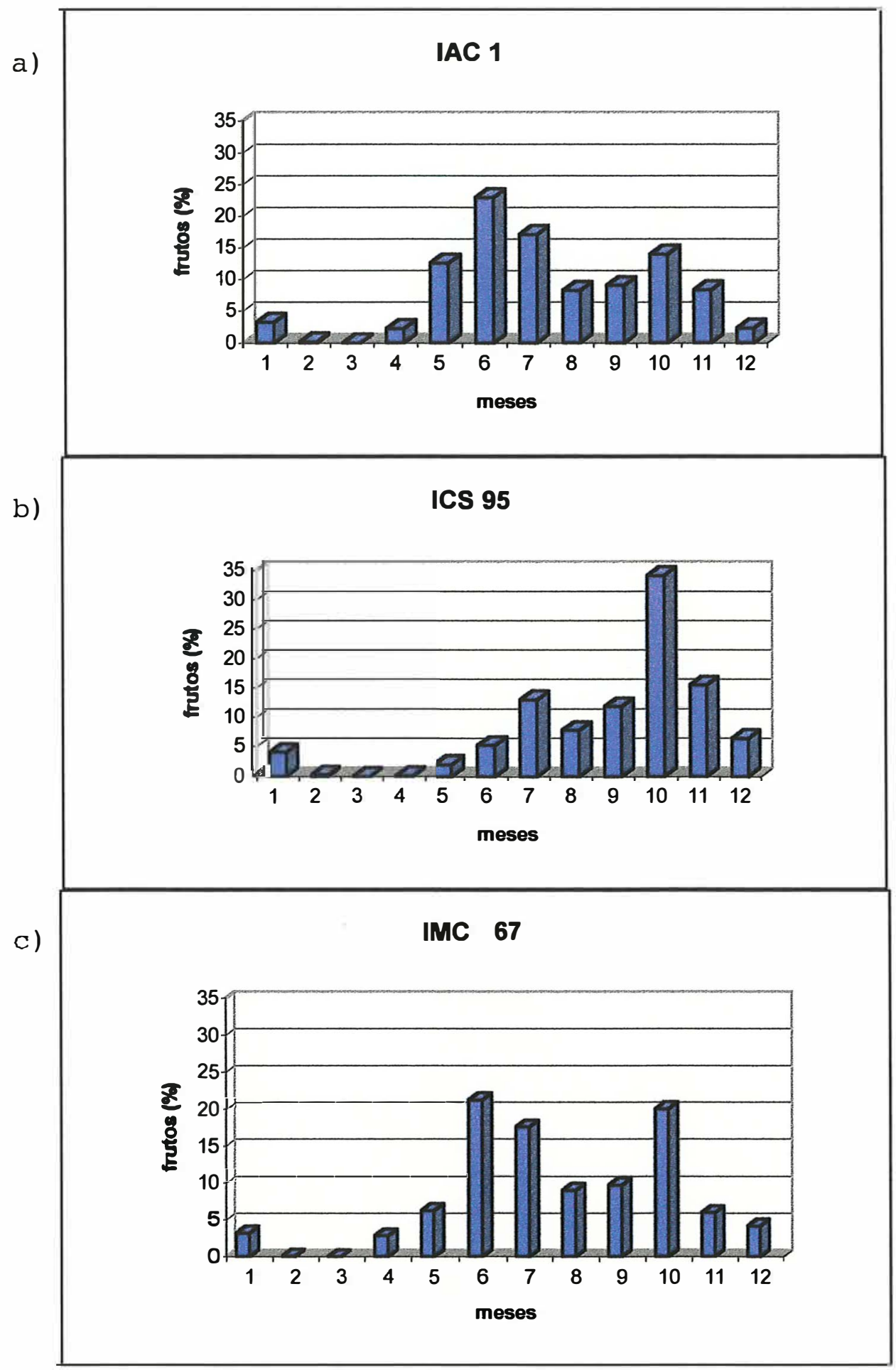

Figura 3 - Proporções de frutos produzidos mês a mês durante o período compreendido entre 1982 a 1994, para três genótipos de cacaueiro produzidos em Pariquera-Açu (SP). a) IAC 1; b) ICS 95; c) IMC 67. 
d)

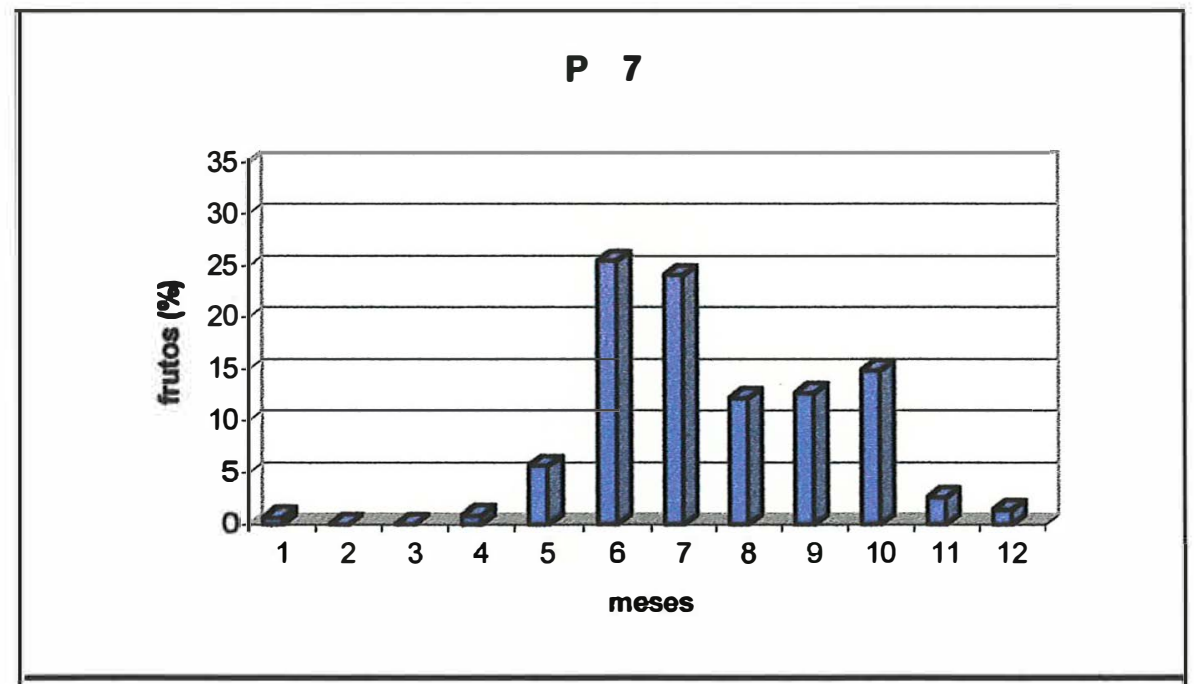

e)
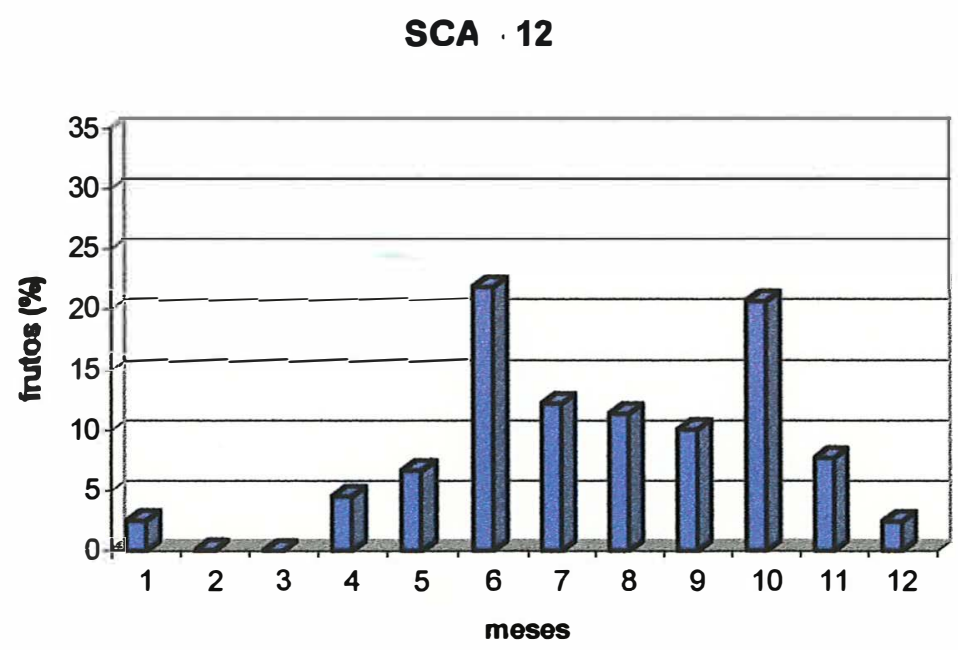

f)

$$
\text { UF - } 29
$$

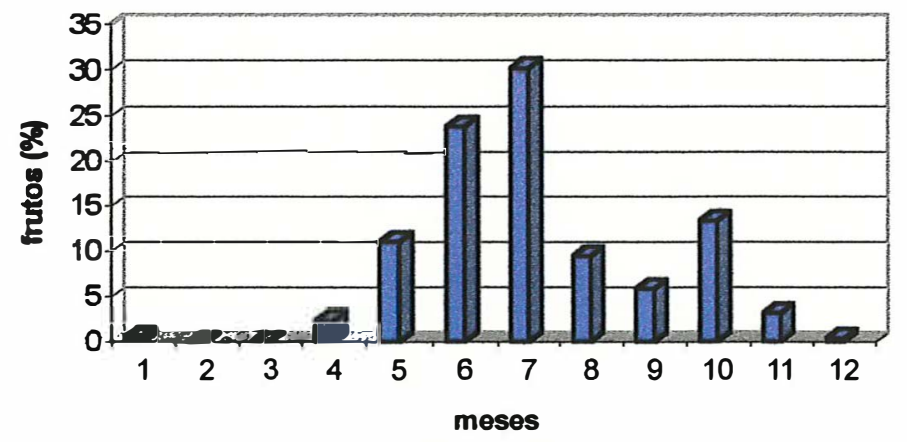

Figura 4 - Proporções de frutos produzidos mês a mês durante o período compreendido entre 1982 a 1994, para três genótipos de cacaueiro produzidos em Pariquera-Açu (SP). d) P 7; e) SCA 12; f) UF 29. 


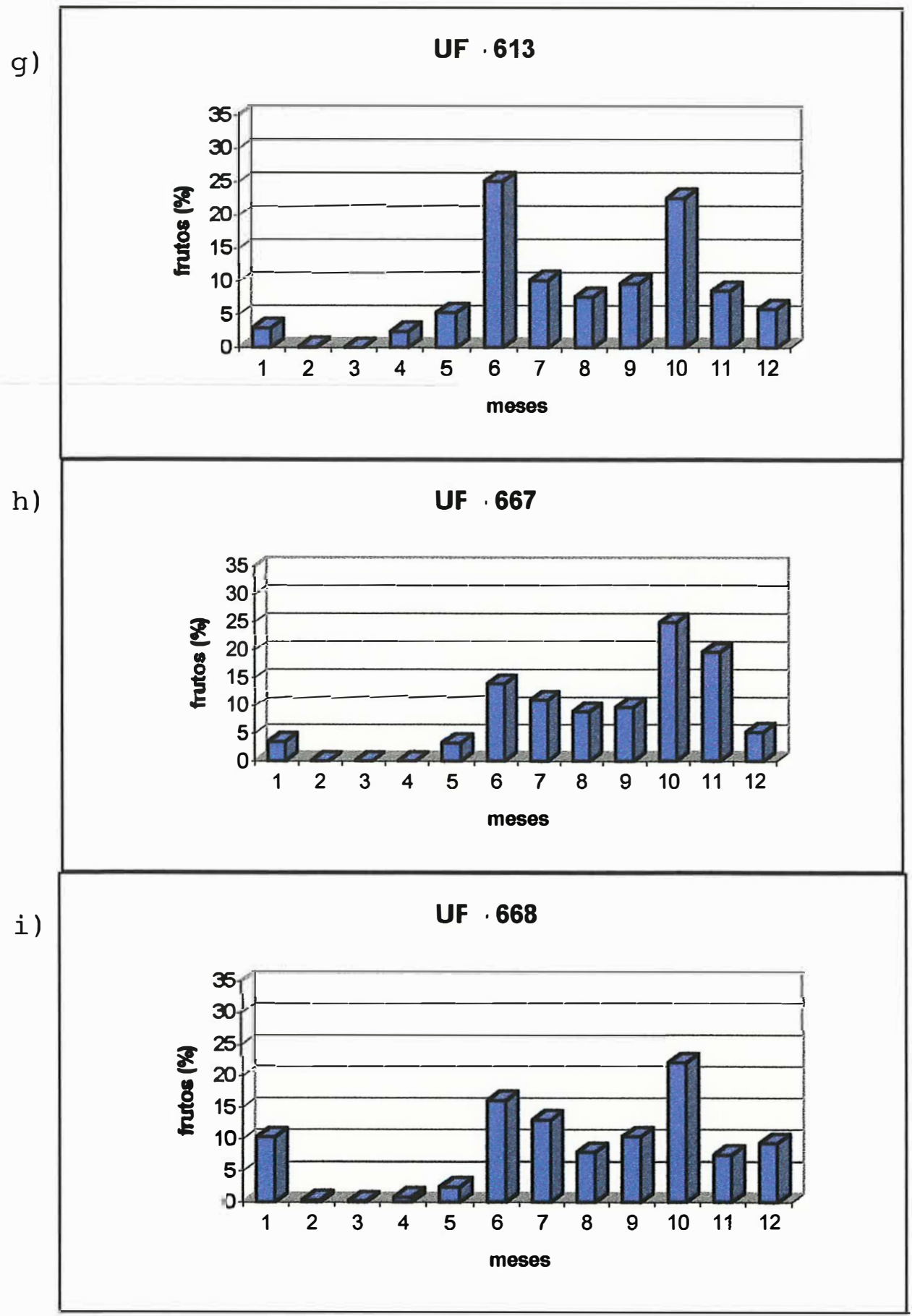

Figura 5 - Proporções dos frutos produzidos mês a mês, durante o período entre 1982 a 1994, para três genótipos de cacaueiro produzidos em PariqueraAçú (SP). g) UF 613; h) UF 667; i) UF 668. 


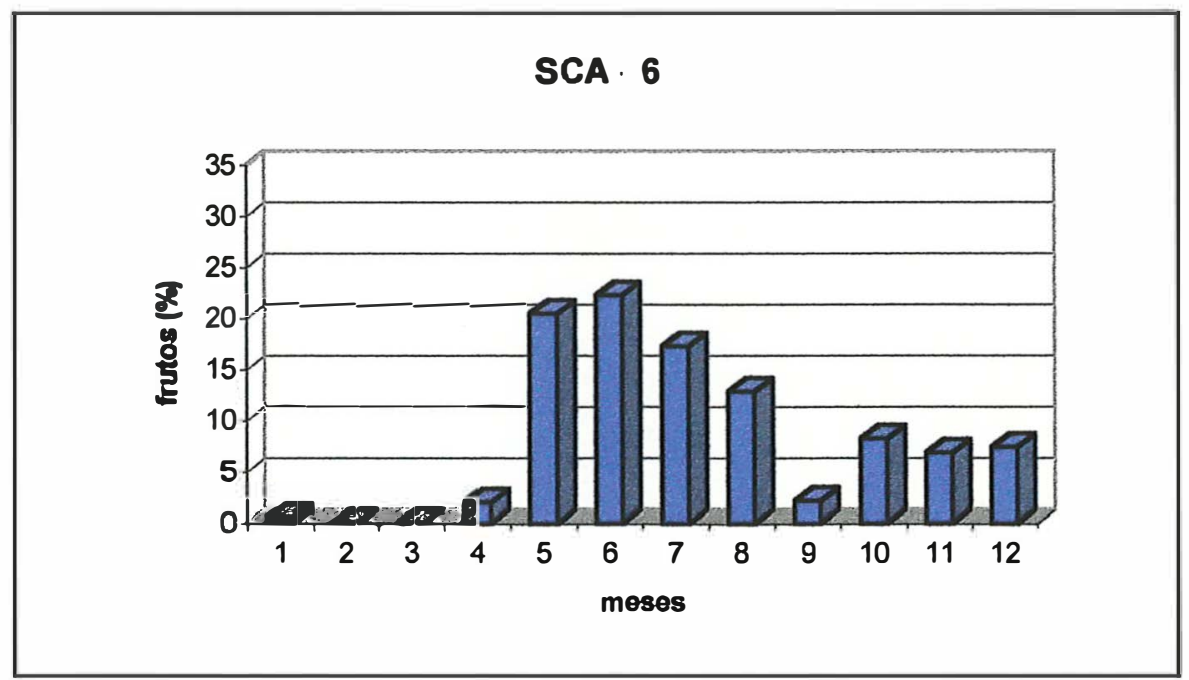

Figura 6 - Proporções de frutos produzidos mês a mês durante o período compreendido entre 1982 a 1994, para o genótipo SCA 6, produzido em Pariquera-Açú (SP). 


\subsection{Teores de gordura}

$\mathrm{Na}$ tabela 14, estão apresentados os teores de gordura determinados pelos métodos de Soxhlet e RNM, tendo havido para ambos diferenças significativas entre genótipos Para o método Soxhlet, considerado padrão para determinação do teor de gordura em sementes de cacau, o teor médio de gordura entre os genótipos foi de $53,19 \%$, com valores entre $51,66 \%$ (ICS95) e 55,30\% (IMC67). Para RNM foi observado teor médio de 53,10\%, com variação entre 51,62\% (ICS95) e 54,99\% (IMC67). Os genótipos IMC67 e UF668 se destacaram dos demais, apresentando teores de gordura acima de $55 \%$ pelo método Soxhlet. IAC1, UF29, P7 e ICS95 produziram menos de 53\%, estando os demais em posição intermediária. Dentro dessas categorias, observou-se razoável consistência de valores, obtidos pelos dois métodos de determinação utilizados. 
Tabela 14 - Teores médios de gordura de sementes de cacau determinados pelos métodos Soxhlet e RNM de dez genótipos ordenados alfabeticamente. ${ }^{1}$

\begin{tabular}{lll}
\hline GENÓTIPOS & \multicolumn{2}{c}{ GORDURA (\%) } \\
\cline { 2 - 3 } & SOXHLET & \multicolumn{1}{c}{ RNM } \\
\hline IAC1 & $52,83 \mathrm{c}$ & $53,20 \mathrm{abc}$ \\
ICS95 & $51,66 \mathrm{c}$ & $51,62 \mathrm{c}$ \\
IMC67 & $55,30 \mathrm{a}$ & $54,99 \mathrm{a}$ \\
P7 & $51,73 \mathrm{c}$ & $52,36 \mathrm{bc}$ \\
SCA6 & $53,06 \mathrm{bc}$ & $52,73 \mathrm{bc}$ \\
SCA12 & $53,51 \mathrm{abc}$ & $52,77 \mathrm{bc}$ \\
UF29 & $52,04 \mathrm{c}$ & $52,98 \mathrm{abc}$ \\
UF613 & $53,35 \mathrm{abc}$ & $53,18 \mathrm{abc}$ \\
UF667 & $53,38 \mathrm{abc}$ & $52,86 \mathrm{bc}$ \\
UF668 & $55,07 \mathrm{ab}$ & $54,36 \mathrm{ab}$ \\
\hline MÉDIA & 53,19 & 53,10 \\
\hline C.V. & 1,97 & 2,06 \\
\hline
\end{tabular}

7 Média de seis frutos analisados.

2 Teores expressos com base na matéria seca

Comparando-se os teores determinados pelo método Soxhlet, com dados obtidos por Pires et al. (1994), para frutos dos mesmos genótipos colhidos em llhéus (BA), no mês de novembro de 1992, observa-se que os genótipos UF668, SCA12, UF667, IAC1, UF29, apresentaram comportamento semelhante, com variações menores que $0,8 \%$, enquanto os genótipos IMC67, UF613, SCA6 e ICS95, variações entre 1 e $2 \%$. As diferenças podem ser 
devidas a efeito do polinizador e a diferenças climáticas entre as duas regiões. No caso do genótipo P7, a grande diferença verificada pode ter sido devida a problema na identificação do genótipo, no momento da instalação da coleção de germoplasma, uma vez que segundo Pires et al. (1994), trata-se de alto produtor de gordura $(58,3 \%)$. A correspondência de dados entre os dois locais, para a maioria dos genótipos, indica que materiais genéticos selecionados na Bahia para alto teor de gordura, apresentam comportamento semelhante na região do presente estudo.

Foi observada correlação altamente significativa entre os métodos utilizados $(r=0,74)$. Essa correlação poderia ser melhorada, se a extração por Soxhlet tivesse sido efetuada na mesma porção da amostra empregada na determinação por RNM, em vez de em uma sub-amostra preparada em tempo diferente, tal como foi observado por Conway e Earle (1963), trabalhando com sementes de várias espécies. Pode-se estimar o teor de gordura Soxhlet, a partir dos teores obtidos por RNM, através da equação de regressão expressa na Figura 7 . $O$ baixo coeficiente de determinação obtido pode ser devido às diferenças existentes entre os materiais genéticos estudados. 
Figura 7 - Equação de regressão entre os teores de gordura de sementes de cacau de dez genótipos, determinados por extração em Soxhlet e RNM.

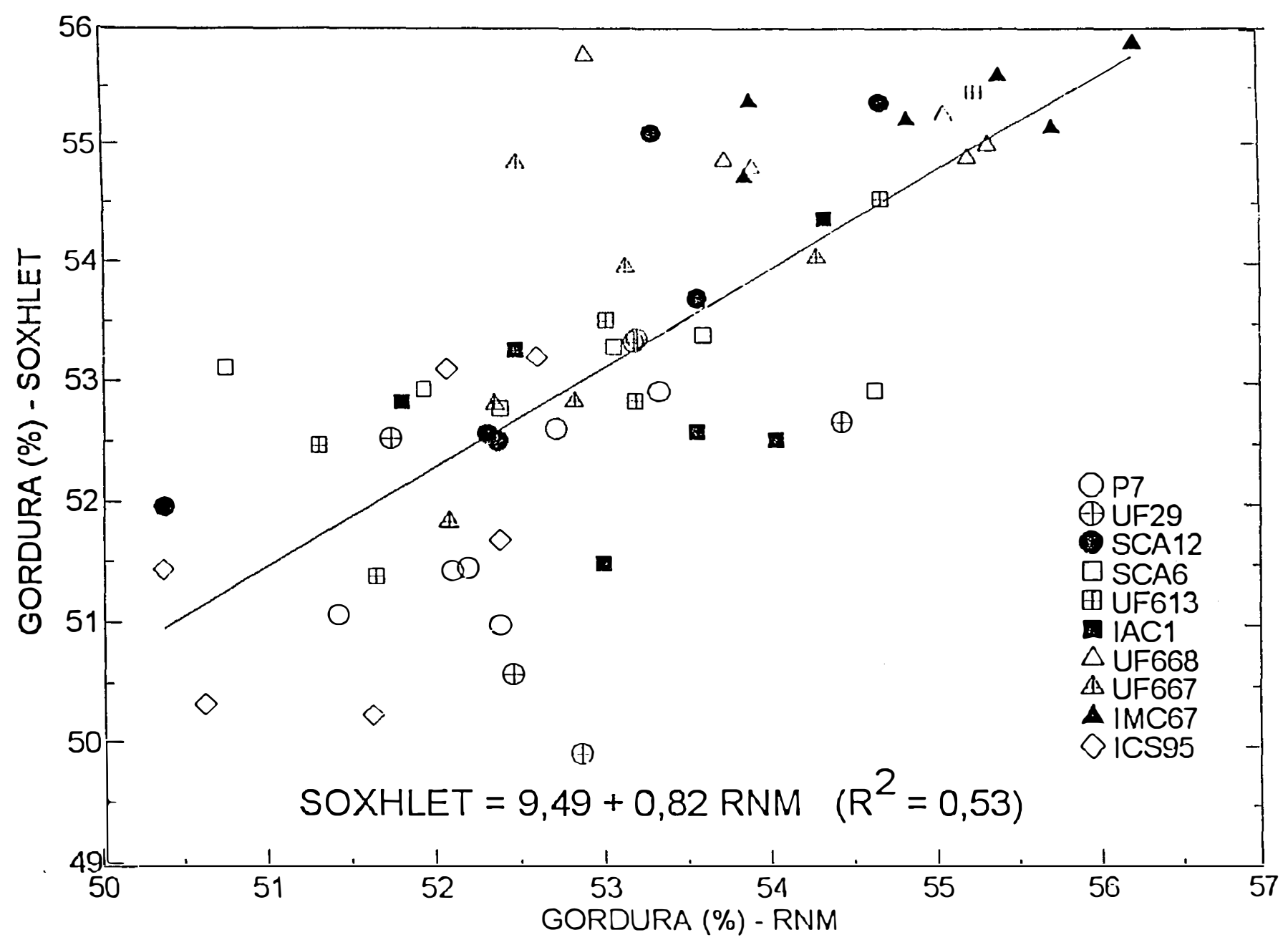


O método RNM foi considerado rápido e preciso para determinação do teor de gordura em produtos de chocolate por Wiggall, Ince e Walker (1970), que atribuiram os valores mais altos obtidos em relação ao Soxhlet, à gordura remanescente, não extraída por este último método. Para sementes de cacau, Beek, Eskes e Toxopeus (1977), encontraram teores de gordura por RNM superiores em 1\%, comparados ao método tradicional de Soxhlet, enquanto Castiñeira (1989) e Gogolewski, Siwczak e Kalucka (1990), obtiveram valores considerados concordantes entre os dois métodos.

\section{5 Ácidos graxos}

A tabela 15 apresenta a composição de ácidos graxos dos dez genótipos estudados. Em geral, os teores de ácidos graxos da manteiga de cacau encontrados na literatura, referem-se a cacau comercial, representando portanto uma mistura de materiais genéticos. Sendo assim, julgamos interessante a oportunidade de comparar os dados obtidos no presente trabalho para material clonal, com os valores obtidos por Figueira ${ }^{4}$ (Tabela 16), para a manteiga de cacau dos mesmos genótipos, para frutos produzidos na Bahia, colhidos em novembro de 1992.

Para o ácido palmítico (16:0), houve diferença significativa entre os genótipos, com os teores variando entre 27,5 (UF29) e $31,6 \%$ (IAC1), com média de $29,3 \%$, maior que as médias de $27,7 \%$ obtida por Figueira (Tabela 16) e de 25,2 e $25,4 \%$ obtidas respectivamente para a manteiga de cacau da Malásia e Gana, por Chin e Zainuddin (1984).

\footnotetext{
${ }^{4}$ Figueira, A. (Centro de Energia Nuclear na Agricultura - CENA/USP). Comunicação pessoal, 1995.
} 
Tabela 15 - Teores de ácidos graxos da manteiga de cacau de dez genótipos ordenados alfabeticamente. ${ }^{1,2}$

\begin{tabular}{|c|c|c|c|c|c|c|c|c|c|c|c|c|}
\hline GENÓTIPO & 14:0 & 16:0 & $16: 1$ & $16: 2$ & 18:0 & $18: 1$ & $18: 2$ & $18: 3$ & 20:0 & $20: 1$ & 22:0 & $24: 0$ \\
\hline IAC1 & 0,10 & $31,6 a$ & 0,27 & 0,25 & $27,6 c$ & $35,4 a b$ & $3,4 a b$ & 0,04 & $0,92 b$ & 0,20 & 0,19 & 0,12 \\
\hline ICS95 & 0,08 & $31,5 a$ & 0,22 & 0,19 & $27,0 \mathrm{c}$ & $36,0 a$ & $3,5 a$ & 0,06 & $0,89 b$ & 0,17 & 0,19 & 0,11 \\
\hline IMC67 & 0,04 & $28,2 b$ & 0,24 & 0,25 & $33,0 a b$ & $33,3 b$ & $3,4 a b$ & 0,03 & $1,01 a b$ & 0,14 & 0,19 & 0,10 \\
\hline P7 & 0,06 & $29,0 b$ & 0,21 & 0,27 & $31,0 a b c$ & $34,5 a b$ & $3,3 a b$ & 0,04 & $1,02 a b$ & 0,20 & 0,20 & 0,11 \\
\hline SCA6 & 0,05 & $28,1 b$ & 0,24 & 0,20 & $30,6 a b c$ & $35,7 b c$ & $3,6 a$ & 0,05 & $0,98 a b$ & 0,18 & 0,19 & 0,10 \\
\hline SCA12 & 0,04 & $29,3 b$ & 0,26 & 0,18 & $30,3 a b c$ & $34,8 a b$ & $3,4 a b$ & 0,04 & $0,99 a b$ & 0,18 & 0,19 & 0,11 \\
\hline UF29 & 0,08 & $27,5 a b$ & 0,40 & 0,27 & $33,8 a$ & $33,2 b$ & $2,9 b$ & 0,04 & $1,10 a$ & 0,19 & 0,20 & 0,12 \\
\hline UF613 & 0,07 & $30,0 a b$ & 0,23 & 0,19 & $29,1 \mathrm{bc}$ & $35,7 \mathrm{bc}$ & $2,9 b$ & 0,05 & $0,99 a b$ & 0,17 & 0,22 & 0,12 \\
\hline UF667 & 0,07 & $29,8 a b$ & 0,23 & 0,28 & $30,0 a b c$ & $35,1 \mathrm{abc}$ & $3,0 a b$ & 0,06 & $0,93 b$ & 0,18 & 0,18 & 0,11 \\
\hline UF668 & 0,07 & $27,8 b$ & 0,25 & 0,27 & $33,0 a b$ & $33,8 \mathrm{ab}$ & $3,3 a b$ & 0,05 & $1,02 a b$ & 0,18 & 0,19 & 0,10 \\
\hline MÉDIA & 0,06 & 29,3 & 0,24 & 0,23 & 30,5 & 34,7 & 3,3 & 0,05 & 0,98 & 0,18 & 0,19 & 0,11 \\
\hline C.V. & - & 3,52 & - & - & 6,02 & 3,15 & 7,72 & - & 6,32 & - & - & - \\
\hline
\end{tabular}

${ }^{-7}$ Valores médios de quatro determinações.

${ }^{2}$ Valores expressos em g 100g-1 de gordura.

14:0 - ácido mirístico; 16:0 - ácido palmítico; $16: 1$ - ácido palmitoléico; 16:2 ácido hexadecadienóico; 18:0 - ácido esteárico; 18:1 - ácido oléico; 18:2 ácido linoléico; 18:3 - ácido linolênico; 20:0 - ácido araquídico; 20:1 - ácido eicosenóico; 22:0 - ácido behênico; 24:0 - ácido lignocérico

Para o ácido esteárico (18:0), houve diferenças significativas entre os genótipos, com média de $30,5 \%$ e teores variando entre 27,0 (ICS95) e 33,8\% (UF29). Figueira (Tabela 16), obteve média de 31,1\% e para a Malásia e Gana as médias foram respectivamente 36,7 e $34,7 \%$ (Chin e Zainuddin, 1984). 
Para o ácido oléico (18:1), houve diferença significativa entre genótipos, sendo a média entre eles $34,7 \%$, com variação entre 33,2 (UF29) e $36,0 \%$ (ICS95). A média foi inferior à obtida por Figueira (Tabela 16) na Bahia (35,3\%), superior à da Malásia (33,4\%) e igual a de Gana $(34,7 \%)$ (Chin e Zainuddin, 1984). Um aumento no teor de ácido oléico, corresponde a um aumento na presença de ácidos graxos insaturados nos triacilgliceróis. 
Tabela 16 - Teores médios de ácidos graxos, triacilgliceróis e valores de dureza (DSC), da manteiga de cacau de nove genótipos, para frutos colhidos na Bahia em novembro de 1992, com base em Figueira ${ }^{5}$.

\begin{tabular}{lccccccccccc}
\hline GENOTIPOS & $\mathbf{1 6 : 0}$ & $\mathbf{1 8 : 0}$ & $\mathbf{1 8 : 1}$ & $\mathbf{1 8 : 2}$ & $\mathbf{2 0 : 0}$ & POP & POS & SOS & POO & SOO & DSC \\
\hline IAC1 & - & - & - & - & - & 29,6 & 38,0 & 13,6 & 3,6 & 2,4 & 75,6 \\
ICS95 & 29,3 & 30,7 & 34,3 & 3,5 & 1,03 & 22,2 & 38,7 & 18,8 & 3,7 & 3,6 & 71,8 \\
IMC67 & 27,9 & 32,0 & 34,6 & 3,8 & 0,90 & 21,4 & 37,4 & 17,9 & 5,7 & 5,5 & 82,1 \\
P7 & 27,2 & 33,4 & 33,4 & 3,8 & 1,01 & 19,1 & 37,7 & 20,9 & 2,6 & 2,7 & 80,5 \\
SCA6 & 27,1 & 28,3 & 38,1 & 4,4 & 0,93 & 17,7 & 31,5 & 16,5 & 9,3 & 9,8 & 68,2 \\
SCA12 & 26,6 & 30,7 & 36,9 & 3,6 & 0,99 & 19,7 & 36,5 & 18,5 & 6,4 & 6,9 & 61,7 \\
UF29 & 28,9 & 31,2 & 33,2 & 3,9 & 1,04 & 19,8 & 36,1 & 18,2 & 3,3 & 3,3 & 68,6 \\
UF613 & 27,5 & 31,0 & 36,1 & 3,6 & 0,93 & 18,7 & 37,5 & 20,8 & 4,5 & 5,3 & 83,4 \\
UF668 & 26,9 & 31,8 & 35,6 & 3,4 & 1,07 & 18,9 & 37,8 & 20,2 & 4,8 & 5,2 & 82,5 \\
\hline MEDIA & 27,7 & 31,1 & 35,3 & 3,8 & 0,99 & 20,8 & 36,8 & 18,4 & 4,9 & 5,0 & 74,9
\end{tabular}

${ }^{-1}$ Valores expressos em $\mathrm{g} 100 \mathrm{~g}^{-1}$ de gordura.

$P$ - ácido palmítico

O - ácido oléico

S - ácido esteárico

(-) Análises não realizadas

Para o ácido linoléico (18:2), houve diferença significativa entre os genótipos, com média de 3,3\% e valores entre 2,9 (UF29, UF613) e 3,6\% (SCA6). A média foi inferior aos $3,8 \%$ obtidos por Figueira (Tabela 16) e superior aos dados da Malásia e Gana, respectivamente 2,5 e 3,1\% (Chin e Zainuddin, 1984). Diferenças inter-genotípicas foram também observadas por Chin e Zainuddin (1984) para os ácidos palmítico, linoléico e linolênico.

Para o ácido araquídico (20:0), houve diferenças significativas entre os genótipos, com média de $0,98 \%$, com variação entre 0,89 (ICS95) e

\footnotetext{
${ }^{5}$ Figueira, A. (Centro de Energia Nuclear na Agricultura - CENA/USP). Comunicação pessoal, 1995.
} 
1,10\% (UF29), inferior à Bahia, Malásia e Gana, respectivamente 0,99; 1,18 e 1,06 .

Foram observadas correlações positivas altamente significativas entre o ácido esteárico e dureza $(r=0,68)$ e correlações negativas altamente significativas entre os ácidos graxos insaturados oléico (18:1) e linoléico (18:2) e dureza, com $r=-0,78$ e $r=-0,53$, respectivamente (Tabela 17). Dados referentes à dureza (DSC) e ponto de fusão (PF), encontram-se na Tabela 21.

Tabela 17 - Estimativa de coeficientes de correlação entre a dureza (DSC) da manteiga de cacau, ponto de fusão (PF) e os teores de alguns ácidos graxos de dez genótipos.

\begin{tabular}{|c|c|c|c|c|c|c|c|c|c|c|}
\hline & $14: 0$ & $16: 0$ & $16: 1$ & $16: 2$ & 18:0 & $18: 1$ & $18: 2$ & $18: 3$ & $20: 0$ & DSC \\
\hline \multirow[t]{2}{*}{ DSC } & $-0,1594$ & $-0,3959$ & 0,1655 & 0,3472 & 0,6849 & $-0,7847$ & $-0,5277$ & $-0,3750$ & 0,4203 & - \\
\hline & ns & * & ns & * & $\star \star \star \star$ & $\star \star * \star$ & $\star \star \star *$ & * & ** & \\
\hline \multirow[t]{2}{*}{ PF } & 0,1054 & $-0,4801$ & 0,4464 & 0,2171 & 0,4334 & $-0,2690$ & $-0,2568$ & $-0,0758$ & 0,3761 & 0,1611 \\
\hline & ns & $\star \star$ & $\star \star$ & ns & $\star *$ & ns & ns & ns & * & ns \\
\hline
\end{tabular}
e $5 \%$ de probabilidade, respectivamente.

Tamanho da amostra: $n=40$.

Foram também identificados os ácidos graxos mirístico (14:0), palmitoléico (16:1), hexadecadienóico (16:2), linolênico (18:3), eicosenóico (20:1), behênico (22:0) e lignocérico (24:0), os quais não foram analisados estatisticamente, uma vez que compreenderam menos que $1 \%$ da composição da manteiga de cacau.

Em geral os teores de ácido palmítico foram maiores para São Paulo que para a Bahia, enquanto os demais foram menores. Quando se observa que os teores dos ácidos graxos insaturados 18:1 e 18:2 foram menores para São Paulo que para a Bahia, deve-se levar em consideração o fato de as temperaturas médias registradas durante o período de crescimento 
dos frutos (quatro meses anteriores à colheita) para ambos os locais foi diferente, especialmente com relação à média das mínimas nos quatro meses anteriores à colheita, $17,7^{\circ} \mathrm{C}$ (dado obtido da CEPLAC / CEPEC / SERAM / Climatologia) para a Bahia e $20,2^{\circ} \mathrm{C}$ para São Paulo (Tabela 5). Os frutos do presente trabalho se desenvolveram durante o período mais quente do ano, ao contrário dos frutos colhidos em novembro na Bahia, desenvolvidos durante os meses mais frios (julho a outubro). Esse fato deve ter contribuido para o aumento da insaturação da manteiga de cacau da Bahia em relação a São Paulo pois, segundo observações de Berbert (1976), um aumento de $3^{\circ} \mathrm{C}$ na média das temperaturas dos quatro meses anteriores à colheita provocou um decréscimo de cerca de $5 \%$ no total de ácidos graxos insaturados, correspondendo a uma elevação no ponto de fusão, de $2^{\circ} \mathrm{C}$.

A relação entre temperaturas baixas e aumento da insaturação de óleos e gorduras, foi estudada por Cheesbrough (1989; 1990), para quem a rota metabólica de síntese de ácidos graxos insaturados inicia-se com a dessaturação do estearoil ligado à proteína de carregamento de acil (ACP), para oleoil-ACP, pela enzima estearoil-ACP dessaturase, não havendo para plantas superiores rota alternativa para produção de oleato. Com a redução da temperatura ambiental, essa dessaturase aumenta significativamente a atividade. Segundo Knutzon et al. (1992), a redução da expressão de estearoildessaturase por expressão do gene no sentido inverso ("anti-sense"), reduziu sensivelmente a dessaturação dos óleos.

$\mathrm{Na}$ Tabela 18, observa-se houve diferença significativa entre os genótipos para a relação entre os ácidos graxos saturados e insaturados, possibilitando, para futuros programas de cruzamento a escolha de materiais genéticos visando elevar a saturação. Alguns genótipos, notadamente UF29, IMC67 e UF668, apresentaram altos teores de ácidos graxos saturados e portanto, relações elevadas, respectivamente 1,70; 1,67 e 1,64. A média de 1,58 , para a relação entre ácidos saturados $e$ insaturados, foi inferior a 
encontrada por Berbert (1976) para frutos colhidos na Bahia de janeiro a julho (média de 1,68 ) e superior às encontradas pelo autor para os demais meses $(1,45)$. Foi inferior à da Malásia e aproximadamente igual a Gana, respectivamente 1,74 e 1,59 (Chin e Zainuddin, 1984). 
Tabela 18 - Teores de ácidos graxos saturados e insaturados e relação entre ácidos graxos saturados e insaturados para dez genótipos ordenados alfabeticamente. $^{1,2}$

\begin{tabular}{llll}
\hline GENOTIPO & SATUR. & INSAT. & SAT/IN \\
\hline IAC1 & 60,4 & 39,6 & $1,53 \mathrm{ab}$ \\
ICS95 & 59,8 & 40,2 & $1,48 \mathrm{~b}$ \\
IMC67 & 62,6 & 37,4 & $1,67 \mathrm{ab}$ \\
P7 & 61,4 & 38,6 & $1,59 \mathrm{ab}$ \\
SCA6 & 60,0 & 40,0 & $1,51 \mathrm{ab}$ \\
SCA12 & 61,0 & 39,0 & $1,56 \mathrm{ab}$ \\
UF29 & 62,9 & 37,1 & $1,70 \mathrm{a}$ \\
UF613 & 60,7 & 39,3 & $1,55 \mathrm{ab}$ \\
UF667 & 61,1 & 38,9 & $1,57 \mathrm{ab}$ \\
UF668 & 62,1 & 37,9 & $1,64 \mathrm{ab}$ \\
\hline MEDIA & 61,2 & 38,8 & 1,58 \\
\hline C.V. & 2,02 & 3,23 & 5,07 \\
\hline
\end{tabular}

${ }^{-1}$ Valores médios de quatro determinações. ${ }^{2}$ Valores expressos em g $100 \mathrm{~g}^{-1}$ de gordura.

É necessário esclarecer que os frutos do genótipo ICS95, para as condições do presente trabalho não amadureceram simultaneamente aos demais, tendo sido colhidos 30 dias após, tempo suficiente para que as temperaturas (médias, máximas e mínimas) nos quatro meses anteriores à colheita, fossem inferiores em $1,7^{\circ} \mathrm{C}$ às verificadas para os frutos colhidos em maio. Esse fato pode ter contribuido para a maior insaturação da manteiga de 
cacau desse genótipo com menor relação entre ácidos graxos saturados e insaturados $(1,48)$.

\subsection{Triacilgliceróis}

$\mathrm{Na}$ tabela 19, estão apresentados os teores de ácidos graxos livres, esteróis, mono, di e triacilgliceróis, para os dez genótipos. Com exceção dos triacilgliceróis, os outros teores não foram analisados estatisticamente em função das pequenas quantidade em que se apresentam na manteiga de cacau. Para ácidos graxos livres a média entre os genótipos foi de $0,97 \%$, com máximo de 1,07 para UF29, estando abaixo de 1,75\% que, segundo Chaiseri e Dimick (1989), representa o máximo valor recomendado pelo The Codex Alimentarius Commission of FAOMHO, para cacau fermentado e seco. A média de $0,25 \%$ para os esteróis está dentro da faixa reportada por Esteves et al. (1991), para sementes fermentadas produzidas pela CEPLAC. Os triacilgliceróis apresentaram média de $97,2 \%$, não tendo havido diferenças significativas entre os genótipos. Esse valor está de acordo com dados relatados por Esteves et al. (1994), para híbridos da CEPLAC. 
Tabela 19 - Teores médios de ácidos graxos livres, esterois, mono, di e triglicerídeos, para dez genótipos ordenados alfabeticamente. ${ }^{1,2}$

\begin{tabular}{llllll}
\hline GENOTIPOS & $\begin{array}{c}\text { Ac.graxos } \\
\text { livres }\end{array}$ & $\begin{array}{c}\text { Mono- } \\
\text { acilgliceróis }\end{array}$ & Esteróis & $\begin{array}{c}\text { Di- } \\
\text { acilgliceróis }\end{array}$ & $\begin{array}{c}\text { Tri- } \\
\text { acilgliceróis }\end{array}$ \\
\hline IAC1 & $1,03 a$ & - & $0,25 a$ & $1,4 a$ & $97,3 a$ \\
ICS95 & $0,96 a$ & - & $0,26 a$ & $1,3 a$ & $97,5 a$ \\
IMC67 & $1,00 a$ & - & $0,23 a$ & $1,7 a$ & $97,1 a$ \\
P7 & $0,93 a$ & - & $0,27 a$ & $1,6 a$ & $97,2 a$ \\
SCA6 & $0,94 a$ & 0,06 & $0,27 a$ & $1,7 a$ & $97,0 a$ \\
SCA12 & $0,93 a$ & - & $0,25 a$ & $1,5 a$ & $97,3 a$ \\
UF29 & $1,07 a$ & - & $0,26 a$ & $1,4 a$ & $97,3 a$ \\
UF613 & $1,00 a$ & - & $0,25 a$ & $1,5 a$ & $97,2 a$ \\
UF667 & $0,90 a$ & - & $0,25 a$ & $1,6 a$ & $97,2 a$ \\
UF668 & $0,97 a$ & - & $0,25 a$ & $1,5 a$ & $97,3 a$ \\
\hline MÉDIA & 0,97 & - & 0,25 & 1,5 & 97,2 \\
\hline C.V. & - & - & - & - & 0,35
\end{tabular}

${ }^{1}$ Valores médios de duas determinações.

${ }^{2}$ Valores expressos em g $100 \mathrm{~g}^{-1}$ de gordura.

Valores médios dos teores de triacilgliceróis para os genótipos estudados, estão apresentados no Tabela 20. Para a oleopalmitoestearina (POS), não houve diferença significativa entre os genótipos, a média entre eles foi de 39,1\% com valores entre 37,4 (IAC1 e ICS95) e 41,2\% (UF29). A média foi superior a determinada por Figueira (Tabela 16) na Bahia $(36,8)$. Dados obtidos por Chaiseri e Dimick (1989), para manteiga de cacau de diversos países variaram entre 35,8 a $41,4 \%$ (Peru e Panamá). Para a Malásia foi de $40,0 \%$. 
Tabela 20 - Valores médios dos teores de triacilgliceróis da manteiga de cacau de dez genótipos ordenados alfabeticamente. ${ }^{1,2}$

\begin{tabular}{lllllllllll} 
GENÓTIPO & POP & PLP & POS & POO & PLS & PLO & SOS & SOO & 000 & SOA \\
\hline IAC1 & $27,8 a$ & 2,8 & $37,4 a$ & $5,2 a$ & 2,9 & 0,80 & $13,2 b$ & $4,0 a$ & 0,88 & 0,70 \\
ICS95 & $27,2 a b$ & 2,5 & $37,4 a$ & $6,2 a$ & 2,9 & 0,87 & $14,0 b$ & $4,5 a$ & 0,93 & 0,75 \\
IMC67 & $21,4 b c$ & 2,3 & $40,8 a$ & $3,0 a$ & 3,7 & 0,53 & $20,3 a b$ & $3,0 a$ & 1,43 & 0,95 \\
P7 & $23,1 a b c$ & 2,5 & $38,1 a$ & $3,8 a$ & 3,0 & 0,74 & $17,7 a b$ & $3,7 a$ & 1,15 & 0,92 \\
SCA6 & $21,3 c$ & 2,7 & $37,8 a$ & $4,7 a$ & 3,4 & 0,82 & $18,2 a b$ & $4,9 a$ & 1,12 & 0,65 \\
SCA12 & $22,4 a b c$ & 2,3 & $39,2 a$ & $4,1 a$ & 3,2 & 0,60 & $18,6 a b$ & $3,9 a$ & 1,27 & 0,98 \\
UF29 & $21,0 c$ & 2,1 & $41,2 a$ & $2,4 a$ & 3,1 & 0,38 & $21,7 a$ & $2,7 a$ & 1,29 & 1,06 \\
UF613 & $25,1 a b c$ & 2,0 & $40,3 a$ & $3,6 a$ & 2,6 & 0,52 & $17,4 a b$ & $3,2 a$ & 0,92 & 0,95 \\
UF667 & $24,8 a b c$ & 2,3 & $38,1 a$ & $4,7 a$ & 2,8 & 0,65 & $16,5 a b$ & $4,2 a$ & 0,98 & 0,84 \\
UF668 & $21,0 c$ & 2,0 & $40,7 a$ & $3,1 a$ & 3,2 & 0,56 & $21,1 a b$ & $3,3 a$ & 1,29 & 0,95 \\
\hline MÉDIA & 23,5 & 2,3 & 39,1 & 4,1 & 3,1 & 0,65 & 17,9 & 3,7 & 1,13 & 0,87 \\
\hline C.V. & 6,28 & 11,02 & 3,15 & 28,53 & 5,04 & - & 10,33 & 27,95 & 16,57 & -
\end{tabular}

\footnotetext{
'Valores médios de duas determinações.

${ }^{2}$ Valores expressos em g. $100 \mathrm{~g}^{-1}$ de gordura.

$P$ - ácido palmítico

O - ácido oléico

L - ácido linoléico

S - ácido esteárico

A - ácido araquídico
}

Para a oleodiestearina (SOS) foram verificadas diferenças significativas entre genótipos, com média de 17,9\% e valores entre 13,2 (IAC1) e $21,7 \%$ (UF29). A média foi inferior à obtida por Figueira (Tabela 16), para frutos dos mesmos genótipos, colhidos no mês de novembro $(18,4 \%)$. Para Chaiseri e Dimick (1989), os valores variaram entre 22,8 e $31,1 \%$, para a Bolívia e Malásia, respectivamente. 
O teor de oleodipalmitina (POP) variou significativamente entre os genótipos. A média verificada foi de 23,5\%, com valores entre 21,0 (UF29 e UF668) e 27,8\% (IAC1). A média foi superior à obtida por Figueira (Tabela 16) (20,8\%). Para Chaiseri e Dimick (1989), variaram entre 17,5 e 22,6\%, respectivamente para Gabon e Bolivia, enquanto para o cacau da Malásia, o teor foi de $18,4 \%$.

Verificaram-se correlações positivas altamente significativas entre os triacilgliceróis mono-insaturados (POS, SOS, SOA) e dureza, com os valores de $r$ de 0,$71 ; 0,49$ e 0,61, respectivamente e correlações negativas altamente significativas entre dureza e POO e SOO (di-insaturados) com valores de $r$ de $-0,80$ e $-0,86$, respectivamente (Tabela 21).

Tabela 21 - Estimativa de coeficientes de correlação entre a dureza (DSC) da manteiga de cacau, e o ponto de fusão (PF) e alguns triacilgliceróis de dez genótipos.

\begin{tabular}{|c|c|c|c|c|c|c|c|c|c|c|}
\hline & POP & PLP & POS & SOS & POO & SO0 & PLO & PLS & 000 & SOA \\
\hline \multirow[t]{2}{*}{ DSC } & $-0,2491$ & $-0,4142$ & 0,7173 & 0,4952 & $-0,8002$ & $-0,8625$ & $-0,6486$ & 0,0116 & 0,4289 & 0,6123 \\
\hline & ns & ns & $\star \star \star \star$ & * & $\star \star \star \star$ & $\star \star \star \star$ & $\star \star$ & ns & ns & $\star \star$ \\
\hline \multirow[t]{2}{*}{ PF } & $-0,5487$ & $-0,4836$ & 0,6135 & 0,6440 & $-0,6058$ & $-0,4515$ & $-0,5608$ & 0,1606 & 0,4706 & 0,4379 \\
\hline & * & * & $\star \star$ & $\star \star$ & $\star \star$ & * & * & ns & * & ns \\
\hline
\end{tabular}

Coeficiente de correlação e nível de significância: ${ }^{* \star *},{ }^{* *},{ }^{*}$, significativo a 0,$1 ; 1$ e $5 \%$ de probabilidade, respectivamente.

Tamanho da amostra: $n=20$.

Manteiga de cacau com altos teores de triacilgliceróis diinsaturados, apresenta baixo grau de dureza (Lehrian, Keeney e Butler, 1980). Os teores dos triacilgliceróis di-insaturados POO e SOO não variaram significativamente entre os genótipos. No entanto, pode-se distinguir entre os genótipos, alguns, demonstrando tendência a sintetizar maiores teores de ambos. Para POO os valores variaram entre 2,4 e 6,2 , com média de $4,1 \%$ e 
para SOO os valores variaram entre 2,7 e 4,9, com média de 3,7. A soma de POO + SOO foi em média 7,8 com valores entre 5,1 (UF29) e 10,7\% (ICS95). Para nove dos dez genótipos estudados, Figueira (Tabela 16) obteve na Bahia média de $9,8 \%$. Tanto para esse autor, como para o presente estudo, alguns genótipos como SCA6 e SCA12, apresentaram teores elevados. Contrariamente, UF29 apresentou valores baixos nos dois locais.

Para Chaiseri e Dimick (1989), a manteiga de cacau da Bahia apresentou um teor de $15 \%$ de POO e SOO combinados, sendo considerada macia. Outras manteigas macias, contendo alto teor de POO + SOO $(>8 \%)$, foram do Brasil, Peru, Cameroon e Gabão. Manteigas de cacau duras, com menos de 5,2\% de POO + SOO foram da Venezuela, Indonésia e Malásia.

Para o presente estudo, em geral, genótipos com baixos teores de $\mathrm{POO}$ + SOO (UF29, IMC67, UF668), apresentaram concomitantemente altos teores de POS e SOS. Tal fato havia sido observado por Chaiseri e Dimick (1989), especialmente para manteigas de cacau da Malásia e llhas Salomão.

\subsection{Dureza}

Com relação à dureza determinada por calorimetria diferencial de varredura (DSC) (Tabela 22), os valores variaram entre 75,6 (ICS95) e 88,3 (UF29), com média de 80,9 . Embora não tenha havido diferença significativa entre os genótipos, nota-se que alguns deles como UF29, P7, IMC67, UF667, UF668 apresentam dureza superior a $80 \%$, indicando capacidade intrínseca de sintetizar gordura mais dura. A média verificada foi superior à média de 74,9 obtida por Figueira (Tabela 16), para frutos dos mesmos genótipos. Essa diferença, por certo se deve às diferenças climáticas entre os dois locais.

$\mathrm{Na}$ latitude do Estado de São Paulo, superior a $20^{\circ} \mathrm{S}$, diferentemente do que ocorre nas regiōes tradicionais de cultivo, localizadas em latitudes menores, ocorre variação estacional acentuada da temperatura, que chega a atingir valores baixos entre os meses de junho a setembro, com 
médias abaixo de $20^{\circ} \mathrm{C}$ (Figura 2). Esse fato por certo acarretará variações estacionais nas características da manteiga de cacau, tornando-se necessário conhecê-las através de estudos complementares. A manteiga de cacau estudada no presente trabalho, foi proveniente de frutos produzidos durante 0 verão.

Para Chaiseri e Dimick (1989), a manteiga de cacau do Extremo Oriente foi considerada dura, devido à uniformidade do clima, com temperaturas elevadas durante o ano todo, em contraposição à da Bahia, onde a média das mínimas usualmente cai abaixo de $20^{\circ} \mathrm{C}$ de junho a setembro. 
Tabela 22 - Valores de dureza (DSC) ${ }^{1,2}$ e pontos de fusão ${ }^{1}$ da manteiga de cacau de dez genótipos ordenados alfabeticamente.

\begin{tabular}{lll}
\hline GENÓTIPOS & DSC & $\begin{array}{c}\text { Ponto } \\
\text { de } \\
\text { fusão }\end{array}$ \\
\hline IAC1 & $79,4 a$ & $30,7 a$ \\
ICS95 & $75,6 a$ & $30,2 a$ \\
IMC67 & $83,3 a$ & $30,6 a$ \\
P7 & $83,9 a$ & $30,1 a$ \\
SCA6 & $77,4 a$ & $30,8 a$ \\
SCA12 & $79,5 a$ & $30,4 a$ \\
UF29 & $88,3 a$ & $31,6 a$ \\
UF613 & $78,3 a$ & $30,8 a$ \\
UF667 & $82,8 a$ & $30,6 a$ \\
UF668 & $81,4 a$ & $31,4 a$ \\
\hline MÉDIA & 80,9 & 30,7 \\
\hline C.V. & 7,89 & 2,30 \\
\hline
\end{tabular}

${ }^{1}$ Valores médios de quatro determinações.

${ }^{2}$ Valores expressos em porcentagem de gordura sólida a $16^{\circ} \mathrm{C}$.

Não houve diferença significativa entre genótipos para ponto de fusão, não tendo sido observada correlação entre este e dureza (Tabela 17) por DSC. A calorimetria diferencial de varredura (DSC), representa um método rápido para a determinação da dureza da manteiga de cacau, propiciando a obtenção de dados que se correlacionam com a dureza determinada pelo método mecânico (Chaiseri e Dimick, 1989). $O$ método leva em consideração o 
comportamento polimórfico bastante complexo da manteiga de cacau (Merken e Vaeck, 1980) e permite comparações de dados de diferentes amostras submetidas a idênticas condições térmicas (Cebula e Smith, 1992). 


\section{CONCLUSÕES}

As características dos frutos e sementes estudados, estão coerentes com aquelas apresentadas nas regiões tradicionais de cultivo pelos mesmos materiais genéticos, com exceção da espessura da casca dos frutos, que para o Estado de São Paulo foi em geral maior.

Para a manteiga de cacau dos genótipos estudados, houve diferenças significativas para os vários parâmetros considerados. Para teor de gordura se destacaram IMC67 e UF668, com médias acima de 55\%.

Alguns genótipos como UF29, IMC67, UF668 e UF667, apresentaram alta relação entre ácidos graxos saturados e insaturados, altos teores dos triacilgliceróis POS e SOS, baixos teores dos triacilgliceróis diinsaturados SOO e POO e portanto se destacaram dentre os demais, apresentando dureza (DSC) elevada, acima de $80 \%$. Tais materiais genéticos podem ser importantes, devido à característica intrínseca para sintetizar manteiga de cacau mais dura, para futuros programas de melhoramento genético na região em estudo.

Em geral, os resultados indicaram que, frutos desenvolvidos durante o período estudado (dezembro a maio), podem produzir manteiga de cacau comercialmente aceitável e que existe potencial para o melhoramento genético visando aprimorar essa característica. 


\section{LITERATURA CITADA}

ABREU Jr., C.H. Estudo da adubação NPK e eficiência de utilização de nutrientes pelo cacaueiro. Piracicaba: ESALQ, Departamento de Solos e Nutrição de Plantas, 1995. 37p.

AGRAWAL, P.K.; VYAS, O.P. Note on the effect of temperature on oil and protein content of the seed of 'Clark 63' soybean (Glycine max (L.) Merr.). Indian Journal of Agricultural Science, v.41, n.12, p. 1122-1123, 1971.

ALVIM, P. de T. Cacao, In: ALVIM, P.de T.; KOZLOWSKI, T.T. (Eds). Ecophysiology of tropical crops. New York Academic Press, 1977, p.279-313.

ARONHIME, J.S.; SARIG, S.; GARTI, N. Reconsideration of polymorphic transformations in cocoa butter using the DSC. Journal of the American Oil Chemists' Society, v.65, n.7, p. 1140-1143, 1988.

BARRAU, J. Sur l'origine du cacaoyer, Theobroma cacao Linné, Sterculiacées. Journ. d'Agric. Trad. et de Bota. Appl. v.26,n.3-4,p. 172-180, 1979.

BEEK, M.A., ESKES, A.B. e TOXOPEUS, H.. Some factors affecting fat content in cacao beans (Theobroma cacao L.), with emphasis on the effect of the pollinator parent. Turrialba, v. 27, n.4,p. 227-232, 1977.

BERBERT, P.R.F. Influência das condições climáticas na composição química e características físicas da manteiga de cacau. Revista Theobroma, v.6,n.3,p. 67-76, 1976.

BERBERT, P.R.F. Determinação do teor, ácidos graxos e características físicas das gorduras das sementes do Theobroma grandiflorum L. e do 
Theobroma bicolor L. em comparação com a gordura do Theobroma cacao L. Revista Theobroma, v.11, n.2, p. 91-98, 1981.

BERBERT, P.R.F. e ALVIM, P.T. . Fatores que afetam o índice de iodo da manteiga de cacau do Brasil. Revista Theobroma, v.2,n.1,p. 3-16, 1972.

BRILHO, R.C.; TUCCI, M.L.S. Cacau (Theobroma cacao L.), Campinas, Coordenadoria de Assistência Técnica Integral, 1986. 25p. (Doc. Técnico, 62).

BRITISH STANDARD INSTITUTION. Methods of analysis of oils and fats. London, British Standard Institution, p.74 (British Standard, 684), 1958.

CASTIÑEIRA, M. La RNM de pulsos en indústrias agroalimentárias. II. Aplicaciones. Revista de Agroquímica y Tecnologia de Alimentos, v.29,n.4,p. 449-468, 1989.

CEBULA, D.J. and SMITH, K.W. Differential scanning calorimetry of confectionery fats: Part II - Effects of blends and minor components. Journal of the American Oil Chemists' Society, n. 69,v.10,p. 992-998, 1992.

CHAISERI, S. and DIMICK, P.S. Lipid and hardness characteristics of cocoa butters from different geographic regions. Journal of the American Oil Chemists' Society, v.66,n.11.p.1771-1776, 1989.

CHAISERI, S.; ARRUDA, D.H.; DIMICK, P.S.; ENRIQUEZ, G.A. Thermal characteristics and composition of fats from Theobroma species. Turrialba, v.39, n.4, p. 468-472, 1989.

CHATT, E.M. History, In: KERTESZ, Z.I. (ed). Cocoa - cultivation, processing, analysis. Interscience Publishers, Inc., New York. p. 1-14.

CHEESBROUGH, T.M. Changes in the enzymes for fatty acid synthesis and desaturation during acclimation of developing soybean seeds to altered growth temperature. Plant Physiology, v.90,p. 760-764, 1989. 
CHEESBROUGH, T.M. Decreased growth temperature increases soybean stearoyl-acyl carrier protein desaturase activity. Plant Physiology, v. 93, p. 555-559, 1990.

CHIN, A.H.G. and ZAINUDDIN, N. Characteristics of Malaysian cocoa butter. In Proceedings of the 1984 International Conference in Cocoa and Coconuts, Malaysia p.63-76, 1984.

CLAPPERTON, J.F. Assesment of cocoa flavour and fat content. In: International workshop on conservation, characterisation and utilization of cocoa genetic resources in the 21st century, Trinidad, 1992. p.111-120.

CONWAY, T.F. and EARLE, F.R. Nuclear magnetic resonance for determining oil content of seeds. Journal of the American Oil Chemists' Society, n.40, p. 265-268, 1963.

CRUZ, M.; GÓMEZ-POMPA,A.; MOTA-BRAVO,L. Origins of cacao cultivation, Nature, v.375, p. 542-543, 1995.

DANTAS, M.A.M.S. Características das manteigas de cacau brasileiras. Arquivos de Bromatologia, v.3, p. 121-123, 1955.

DEPARTAMENTO NACIONAL DE METEOROLOGIA. Normais climatológicas (1961/1990). Ministério da Agricultura e Reforma Agrária, Brasília. 84p. 1992.

DIMICK, P.S. Principles of cocoa butter crystallization. The Manufacturing Confectioner, v. 71n.5, p.109-114, 1991.

DIMICK, P.S.; MANNING, M. Thermal and compositional properties of cocoa butter during static crystallization. Journal of the American Oil Chemists' Society, v. 64, n. 12, p. 1663-1669, 1987.

DITTMAR, H.F.K.; RAIMANN, E.Z. Sobre as perdas aparentes de gordura na torrefação de cacau. Instituto de Tecnologia da Bahia, Salvador (BA), 1956. $7 p$. 
DITTMAR, H.F.K.; DUARTE, J.H. Cocoa fat from Bahia: I. Industrial cocoa butter. Anais da Associação Brasileira de Química, v.19, p. 93-101, 1960a.

DITTMAR, H.F.K.; DUARTE, J.H. Cocoa fat from Bahia: II. Fats from different varieties of cocoa during the fermentation process. Anais da Associação Brasileira de Química, v.19, p. 103-109, 1960b.

DORNBOS, D.L.; MULLEN, R.E. Soybean seed protein and oil contents and fatty acid composition adjustment by drought and temperature. Journal of the American Oil Chemists' Society, v.69, n.3, p. 228-231, 1992.

DUARTE, J.O. Demanda internacional por importação de cacau. Viçosa (MG), 1987. 76p. Dissertação de Mestrado. Universidade Federal de Viçosa.

D'UTRA, G. Instruções sobre a cultura e o benefício do cacau. Boletim de Agricultura, v.10,p. 539-581, 1909.

EL-SAIED, H.M.; MORSI, M.K.; AMER, M.M.A. Composition of cocoa shell fat as related to cocoa butter. Z. Ernährungswissen, v.20, p.145-151, 1981.

ENRIQUEZ, G. Curso sobre el cultivo del cacao. Turrialba:CATIE, 1985. 240p.

ENRIQUEZ, G.; SORIA, J.V. Catálogo de cultivares de cacao. Turrialba: IICA, 1967.

ESTEVES, W., BARRERA-ARELLANO, D., NUNES, M.L., GALVÃO, M.T.E.L., CARVALHO, R.V. e ANTONIASSI, R. Teores de componentes lipídicos de amêndoas de quatro cultivares de cacau. Boletim da Sociedade Brasileira de Ciência e Tecnologia de Alimentos, v.25, n.1, p.22-26, 1991.

ESTEVES, W., BARRERA-ARELLANO, D., NUNES, M.L., GALVÃO, M.T.E.L. e ANTONIASSI, R. Composição de ácidos graxos e triglicerídios de quatro cultivares de cacau. Ciência e Tecnologia de Alimentos, v.14, n.2, p. 247-252, 1994. 
FIGUEIRA, A .; JANICK, J. Somatic embryogenesis in Theobroma cacao L. In: JAIN, S.; GUPTA, P.; NEWTON, R. (eds.), Somatic Embryogenesis in Woody Plants, p. 291-310, 1994.

FIGUEIRA, A.; JANICK, J.; LEVY, M.; GOLDSBROUGH, P. Reexamining the classification of Theobroma cacao L. using molecular markers. Journal of the American Society for Horticultural Science, v.119, n.5, p. 10731082, 1994.

GARCÉS, R.; SARMIENTO, C.; MANCHA, M. Oleate from triacylglycerols is desaturated in cold-induced developing sunflower (Helianthus annuus L.) seeds. Planta, v. 193, p. 473-477, 1994.

GEERAERT, E. and SANDRA, P. Capillary GC of triglycerides in fats and oils using a high temperature phenylmethylsilicone stationary phase. Part II. The analysis of chocolate fats. Journal of the American Oil Chemists' Society, v. 64, n.1,p. 100-105, 1987.

GERRIT, A. R. - ICCO Cocoa Newsletter, n. 7, 1994.

GOGOLEWSKI, M.; SIWCZAK, C.; KALUCKA, M. Zawartosc tluszczu oznaczona metodami NMR I Soxhleta w produktach otrzymywanych z ziarna kakaowego. Roczniki Akademii Rolniczej w Poznaniu, v. 218, p. 29-34, 1990.

GOLOMBECK, S.D.; SRIDHAR, R.; SINGH, U. Effect of soil temperature on the seed composition of three spanish cultivars of groundnut (Arachis hypogaea L.). Journal of Agriculture and Food Chemistry, v.43, p. 2067-2070, 1995.

GRANATO, L. Campo de esperiências de lguape. In: SECRETARIA DA AGRICULTURA COMÉRCIO E OBRAS PÚBLICAS DO ESTADO DE SÃO PAULO. Relatório 1903. São Paulo, 1904.

. Notas sobre a cultura do cacaueiro. Boletim de Agricultura, São Paulo,9,p.246-249, 1908. 
. O cacaueiro no Brasil. Boletim de Agricultura, São Paulo, 10, p.893913, 1909.

HARDY, F. Manual de cacao. Turrialba:IICA, 1961, 439p.

HARO, A.; FERNANDEZ-MARTINEZ, J. Evaluation of wild sunflower (Helianthus) species for high content and stability of linoleic acid in the seed oil. Journal of Agricultural Science, v.116, p. 359-367, 1991.

HARRIS, H.C.; McWILLIAM, J.R.; MASON, W.K. Influence of temperature on oil content and composition of sunflower seed. Australian Journal for Agriculture Research, v.29, p. 1203-1212, 1978.

HARRIS, H.C.; McWILLIAM, J.R.; BOFINGER, V.J. Prediction of oil quality of sunflower from temperature probabilities in Eastern Australia. Australian Journal for Agriculture Research, v.31,p.477-488, 1980.

HARWOOD, J.L. Plant acyl lipids: structure, distribution, and analysis. In: The

Biochemistry of Plants, Vol. 4. Academic Press, Inc. 1980. p. 1-55.

HARWOOD, J.L.; PAGE, R.A. Biochemistry of oil synthesis. In: Murphy, D.J.

(Ed.) Designer oil crops: breeding, processing, and biotechnology.. $\mathrm{VCH}$, Weinheim, Germany, 1994. p. 165-194.

HILL, A.B.; KNOWLES, P.F. Fatty acid composition of the oil of developing seeds of different varieties of safflower. Crop Science, v.8, p. 275$277,1968$.

"HISTORICUS". Cocoa: all about it. Sampson Low, Marston \& Company (ed.). London, 1892. 114p.

INTERNATIONAL COCOA ORGANIZATION. Production of cocoa beans by country. Quarterly Bulletin of Cocoa Statistics, v.23,n.1, 1996.

INTERNATIONAL UNION OF PURE AND APPLIED CHEMISTRY. Method 1.123. Determination of Oil Content (Low Resolution Nuclear Magnetic Ressonance Method). In: Paquot, C.; Hautfenne, A. (Ed.). Standard Methods for the Analysis of Oils, Fats and Derivatives, 7th Ed.. Blackwell Scientific Publications, Oxford, 1987. 
JANICK, J. Embryogenics: The technology jof obtaining useful products from the culture of assexual embryos. In: CROCOMO, O.J.; SHARP, W.R.; EVANS, D.A.; BRAVO, J.E.; TAVARES, F.C.A.; PADDOCK, E.F.(Eds.) Biotechnology of plants and microorganisms. Ohio State University Press, 1986. p. 97-117.

JOHNSTON, G.M. Fats and processes used in manufacturing chocolate and confectionery coatings. Journal of the American Oil Chemists' Society, v.49, p. 462-467, 1972.

KAVANAGH, T.E.; REINECCIUS, G.A.; KEENEY, P.G.; WEISSBERGER, W. Mold induced changes in cacao lipids. Journal of the American Oil Chemists' Society, v. p. 344-346, 1970.

KNUTZON, D.S., THOMPSON, G.A., RADKE, S.E., JOHNSON, W.B., KNAUF, V.C. and KRIDL, J.C. Modification of Brassica seed oil by antisense expression of a stearoyl-acyl carrier protein desaturase gene. In Proceedings Natl. Acad. Sci. v. 89,p. 2624-2628, 1992.

LACHENAUD, $P$. Effet de quelques variables saisonnières sur la relation entre poids de cabosse et poids de fèves fraîches chez le cacaoyer. Café, Cacao, Thé, v. 35, n.2, p.113-120, 1991.

LEHRIAN, D.W. and KEENEY, P.G. Changes in lipid components of seeds during growth and ripening of cacao fruit. Journal of the American Oil Chemists' Society, v. 57, p. 61-65, 1980.

LEHRIAN, D.W., KEENEY, P.G. and BUTLER, D.R. Triglyceride characteristics of cocoa butter from cacao fruit matured in a microclimate of elevated temperature. Journal of the American Oil Chemists' Society, v.57, p. 6669, 1980.

LOPEZ, A.S. Lipids from the seeds of passion flower fruit (Passiflora edulis). Revista Theobroma, v.10, n.1, p. 47-50, 1980. 
LOVEGREN, N.V.; GRAY, M.S.; FEUGE, R.O. Effect of liquid fat on melting point and polymorphic behavior of cocoa butter and a cocoa butter fraction. Journal of the American Oil Chemists' Society, v.53, p. 108-111, 1976.

MARTIN, B.A.; WILSON, R.F.; RINNE, R.W. Temperature effects upon expression of a high oleic acid trait in soybean. Journal of the American Oil Chemists' Society, v.63, n. 3, p.346-352, 1986.

McNAIR, J.B. Plant fats in relation to environment and evolution. In:

Studies in Plant Chemistry. Los Angeles, Westernlore Press, 1965. p. 315-364.

MENEZES, J.A.S.; BARROCO, H.E. Relações básicas da demanda mundial por cacau. Série de Estudos Econômicos, n.9. Coordenadoria de Assuntos Econômicos e Internacionais. Brasília, DF, 1986. 77p.

MENEZES, J.A.S,; CARMO-NETO, D. A modernização do agribusiness cacau. Campinas:Fundação Cargill, 1993. 233 p.

MERKEN, G.V. and VAECK, S.V. Etude du polymorphisme du beurre de cacao par calorimétrie DSC. Lebensmittel-Wissenschaft und Technologie, v. 13,n.6,p. 314-317, 1980.

MINNIFIE, B.W. Cocoa butter and replacemente fats. In:Chocolate, cocoa and confectionary science and tecnology. Westport, AVI, 1989. 480p.

MORGENTAL, A.; BATOLLA JUNIOR, F.; PAIVA, I.P. et al. Mapa geológico integrado. São Paulo, Projeto SUDELPA, Cia. de Pesquisa e Recursos Minerais, 1974.

NOGUEIRA, E.A. Estudo sobre a viabilidade econômico-financeira da cacauicultura no Estado de São Paulo. São Paulo, 1986. 133 p. Dissertação de Mestrado - Escola de Administração de Empresas de São Paulo, da Fundação Getúlio Vargas.

OFFICE INTERNATIONAL DU CACAO ET DU CHOCOLAT. Determination of fat. In Méthodes d'analyse. Zürich, Verlag Max Glättli. 1 p. (Analytical Method, Page 8a-E/1963), 1963. 
OHLROGGE, J.B. Design of new plant products: engineering of fatty acid metabolism. Plant Physiology, v.104,p. 821-826, 1994.

PARADIS, L. Le cacao précolombien: monnaie d'échange et breuvage des dieux. Journ. d'Agric. Trad. et de Bota. Appl. v.26, n.3-4, p. 181-199, 1979.

PATEL, V.K.; SHANKLIN, J.; FURTEK, D.B. Changes in fatty-acid composition and stearoyl-acyl carier protein desaturase expression in developing Theobroma cacao L. embryos. Planta, v.193, p. 193-198, 1994.

PEETERS, A. Controverses sur des vertus du cacao et les manieres de preparer le chocolat (XVI-XVIII siécles). Journ. d'Agric. Trad.et de Bota. Appl. v.26,n.3-4,p. 201-216, 1979.

PENCE, V.C.; HASEGAWA, P.M.; JANICK, J. Sucrose-mediated regulation of fatty acid composition in asexual embryos of Theobroma cacao. Physiologia Plantarum, v.53, p. 378-384, 1981.

PIRES, J.L., CASCARDO, J.C.M., LAMBERT, S.V. and FIGUEIRA, A. In Proceedings of the International Workshop on Cocoa Breeding Strategies, Kuala Lumpur, p. 148-154, 1984.

POPPER, K. A lógica da pesquisa científica. $4^{\text {a. }}$ ed. São Paulo: Editora Cultrix, 1993. 567p.

RENNIE, B.D.; TANNER, J.W. Fatty acid composition of oil from soybean seeds grown at extreme temperatures. Journal of the American Oil Chemists' Society. v.66, n.11, p.1622-1624, 1989.

RIBEIRO, N.C.A.; SACRAMENTO, C.K.; BARRETO, W.G.; SANTOS FILHO, L.P. Características físicas e químicas de frutos de cupuaçuzeiro (Theobroma grandiflorum) do sudeste da Bahia. Agrotrópica, v.4, n.2, p. 33-37, 1992.

SAKAI, E. e LEPSCH, I.F. Levantamento pedológico detalhado da Estação Experimental de Pariquera-Açú. Instituto Agronômico, Campinas. Boletim Técnico $n^{\circ} 83.56 p, 1984$. 
SECRETARIA DA AGRICUTURA DO ESTADO DE SÃO PAULO. Zoneamento agricola do Estado de São Paulo. São Paulo, Atlas, 1974. v.1, 165p.

SEILER, G.J. Analysis of the relashionships of environmental factors with seed oil and fatty acid concentrations of wild annual sunflower. Field Crops Research, v.15, p. 57-62, 1986.

SILVER, J.G.; ROCHESTER, C.P.; BISHOP, D.G.; HARRIS, H.C. Unsaturated fatty acid synthesis during the development of isolated sunflower (Helianthus annuus L.) seeds. Journal of Experimental Botany, v. 35, n. 159, p. 1507-1514, 1984.

STEEL, R.G. and TORRIE, J.H. Principles and procedures of statistics. New York, MacGraw-Hill. 632 p. 1980.

TOXOPEUS, $H$. and JACOB, $V$. Pod and bean value studies on hand pollinated pods. In Cocoa Research Institute of Nigeria, Annual Report 1967-1968. p. 49-51, 1968.

TOXOPEUS, $H$. and WESSEL, M. Studies on pod and bean values of Theobroma cacao L. in Nigeria. I. Environmental effects on West African Amelonado with particular attention to annual rainfall distribution. Netherlands Journal of Agricultural Science v.18,p.132-139, 1970.

UNGER, P.W. Planting date effects on growth, yield, and oil of irrigated sunflower. Agronomy Journal, v.72, p. 914-916, 1980

VASCONCELOS, M.N.L.; SILVA, M.L.; MAIA, J.G.S.; GOTTLIEB, O.R. Estudo químico das sementes do cupuaçu. Acta Amazonica, v.5, n.3, p.293-295, 1975.

VELLO, F., GARCIA, J.R. e MAGALHÃES, W.S. Produção e seleção de cacaueiros híbridos na Bahia. Revista Theobroma, v.2,n.3,p. 15-35, 1972.

WADA, H.; GOMBOS, Z.; SAKAMOTO, T. et al. Fatty acid desaturation in cyanobacteria. In: Biochemistry and Molecular Biology of Membrane 
and Storage Lipids of Plants. MURATA, N.; SOMERVILLE, C.R. (Eds). , 1993, 259p.

WIGGALL, P.G., INCE, A.D. and WALKER, E. The rapid determination of fat in chocolate and related products using low resolution nuclear magnetic resonance. Journal of Food Technology, v. 5, p. 353-362, 1970.

WEN, M.C.; GERMAN, B.; KINSELLA, J.E. Cocoa bean cell and embryo culture. Journal of the American Oil Chemists' Society, v. 61, n.11, p. 1720-1724, 1884.

WILCOX, J.R.; CAVINS, J.F. Normal and low linoleic acid soybean strains: response to planting date. Crop Science, v.32, p. 1248-1251, 1992.

WOOD, G.A.R. Quality and inspection. In Cocoa. 4.ed., G.A.R.Wood and R.A. Lass ed. Longman Inc., New York, p. 505-527, 1985.

WRIGHT, D.C.; JANICK, J.; HASEGAWA, P.M. Temperature effects on in vitro lipid accumulation in asexual embryos of Theobroma cacao L. Lipids, v.18, n.12, p. 863-867, 1983.

YERMANOS, D.M.; HEMSTREET, S.; GARBER, M.J. Inheritance of quality and quantity of seed-oil in Safflower (Carthamus tinctorius L.). Crop Science, v.7, p. 417-422, 1967. 


\section{APÊNDICE 1}

Cromatogramas obtidos pela técnica de Cromatografia Gasosa Capilar, mostrando a composição em ácidos graxos dos dez genótipos estudados. Cada cromatograma corresponde à análise das sementes de um único fruto. 


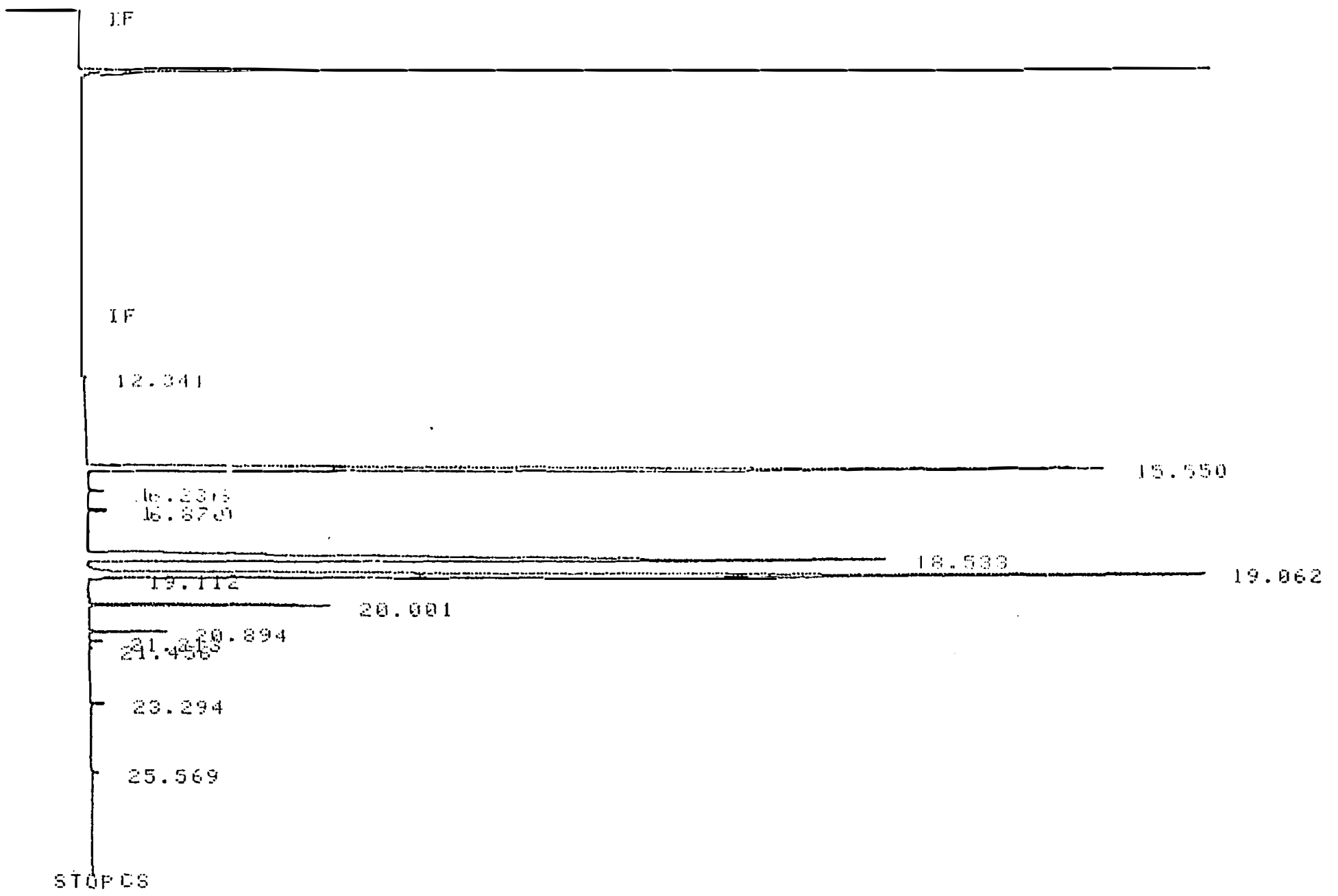

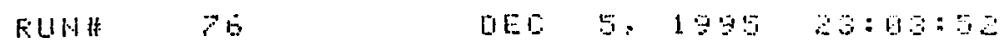

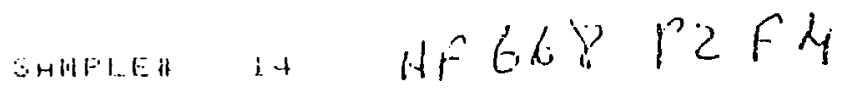

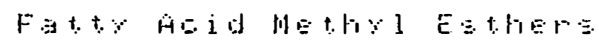

HOBM-AFEA

FET TIFE

$12.3+1 \quad \mathrm{BE}$

$15.559 \quad F E$

1.6.23E PE

1E. 670 PE

1. 530 PE

19.062 EV

$19.112 \quad 46$

2 . 0101 "

Z日, 8944 EE

Z1.213 EE

$2.456 \quad F E$

$23.294 \quad \mathrm{EE}$

$2.5 .56 \quad F E$

\begin{tabular}{|c|c|}
\hline HEEH & H \\
\hline 859 & .054 \\
\hline 97351 & .098 \\
\hline 2614 & $.19+2$ \\
\hline 3179 & .94 if \\
\hline 37693 & .139 \\
\hline 97607 & .108 \\
\hline 369 & .63 \\
\hline 34439 & .94 \\
\hline 11514 & .04 \\
\hline 2070 & . 19.1 \\
\hline 6.54 & $.5 \cdot$ \\
\hline 2134 & 0 \\
\hline 1185 & .0 \\
\hline
\end{tabular}

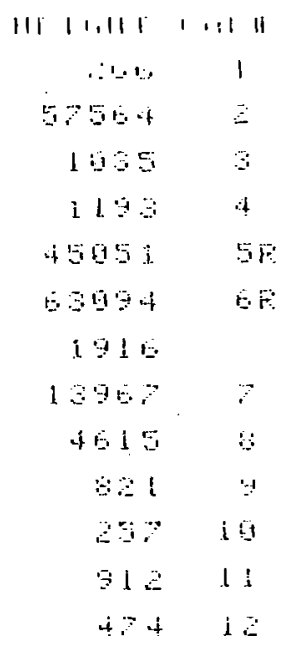

TOTHL AREA=1181990

MUL FAETOFE=1. BOBEE+ GB 


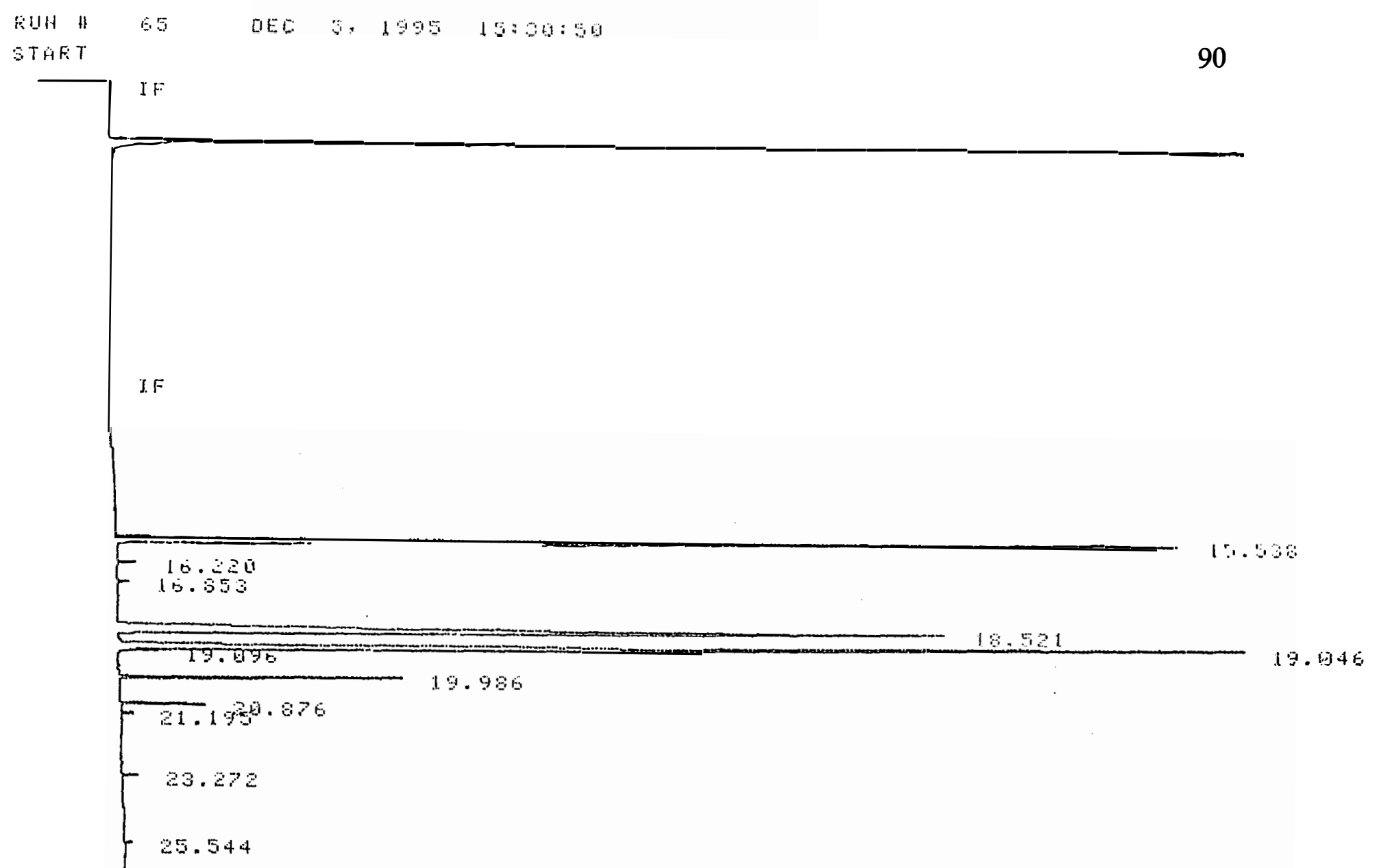

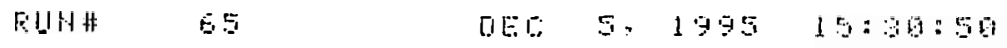

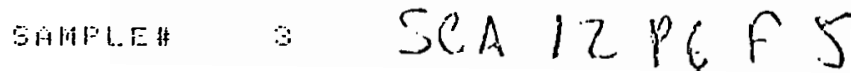

Fat t,y hei d Methos Estrers.

\begin{tabular}{|c|c|c|c|c|c|c|c|}
\hline \multicolumn{8}{|c|}{ HOFM-ABEA } \\
\hline FiT & TYFE & HPEH & WOTH & 111.19 .111 & $1 ., 111$ & $1+411+111$ & llini: \\
\hline 15.538 & PE & 359105 & .100 & 5943 & $\therefore$ & $\therefore \cdot 1: \therefore 4$ & $16: \cdots$ \\
\hline 16.220 & $P E$ & 3121 & .042 & 1245 & 3 & .250 & $16: 1$ \\
\hline 16.953 & $F \cdot E$ & 2164 & .196 & 783 & 4 & .171 & $18: 2$ \\
\hline 18.521 & E: & $39+291$ & $.1+1$ & 4555 & $5 E$ & $2 \cdot 6+5$ & $18: 0$ \\
\hline 19.945 & Ev & $412 こ 70$ & .107 & 53951 & $\dot{\theta}$ & 39.905 & $15: 1$ \\
\hline 19.096. & $\forall 8$ & 4575 & .952 & 要 & & 4000 & \\
\hline 19.986 & $P E$ & .11923 & .042 & 16160 & $\because$ & 2.39 & $18: 2$ \\
\hline $29.97 \%$ & $E B$ & 12556 & .942 & 5630 & 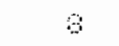 & i. 629 & $20: 0$ \\
\hline 21.195 & $F E$ & 2134 & .041 & 859 & 9 & $\cdot \quad .173$ & $20: 1$ \\
\hline $23.27 z$ & $F E$ & 2243 & .037 & 1017 & $1 i$ & .132 & $22: 0$ \\
\hline 25.544 & $F B$ & 1561 & .050 & 520 & d.: & .126 & $24: 0$ \\
\hline
\end{tabular}


EUA H 7 QE
GTAR

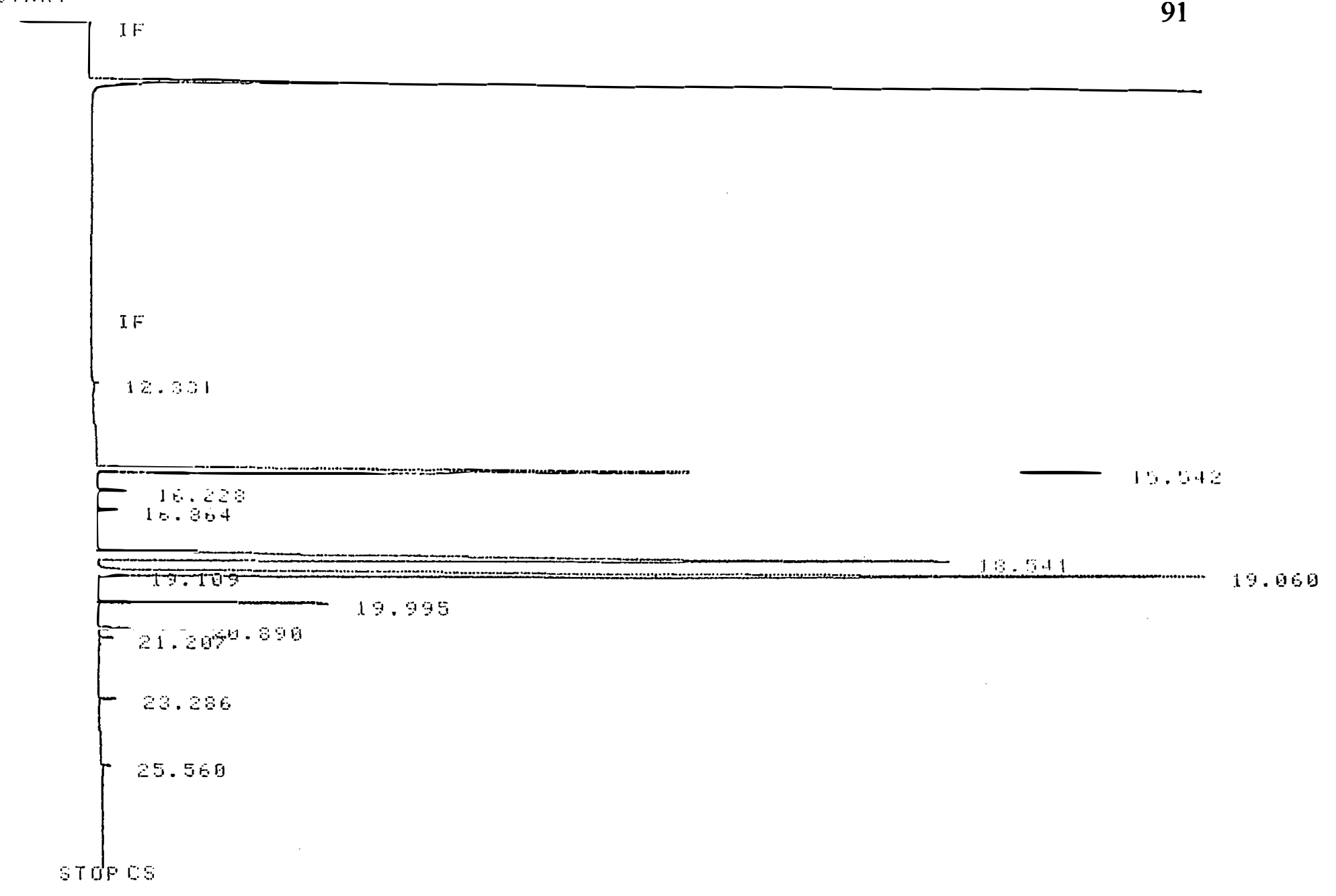

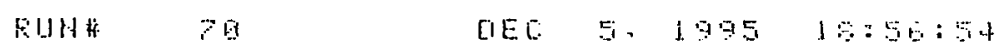

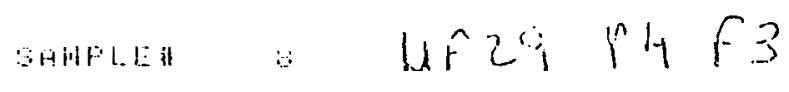

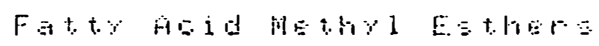

WIEA-HEEA

ET TYFE

$1 \therefore \therefore 1$ FE

i 5.5420

15.228 FE

$15.564 \quad 8 \mathrm{E}$

$16.541 \quad F$

19.656

$19.199 \quad \forall \mathrm{E}$

$19.995 \quad \because 6$

20.895 छE

21. $2 \mathrm{BO}$ हE:

$23.260 \quad E E$

$25.560 \quad F E$

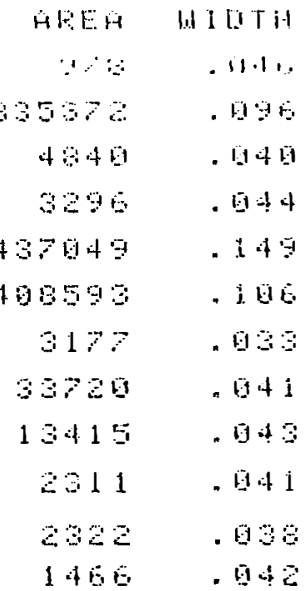

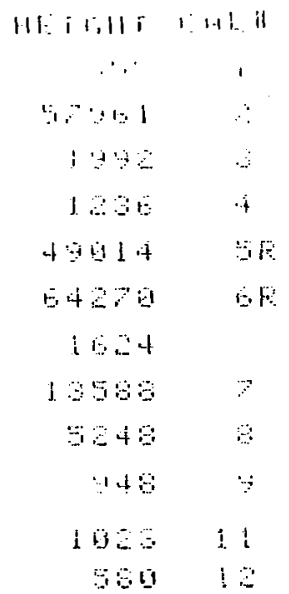

\begin{tabular}{|c|c|}
\hline HWl1:11: & |W1 \\
\hline$\therefore$ & $11 \ldots$ \\
\hline$\therefore y+4$ & $1 \because: 1.1$ \\
\hline .969 & $16: 1$ \\
\hline .264 & $18: 2$ \\
\hline $25 \times 15 i$ & $19: 0$ \\
\hline$a \cdot 86$ & $15:$ \\
\hline .000 & \\
\hline$\therefore \approx 12$ & 16 \\
\hline 1.079 & $20: 0$ \\
\hline $.1 \mathrm{at}$ & $20:$ \\
\hline .18 & \\
\hline $.1 \mathrm{i}:$ & \\
\hline
\end{tabular}




\begin{tabular}{|c|c|c|c|c|}
\hline FUHA \# & 57 & UED & 195 & $16: 8: 13: 5$ \\
\hline
\end{tabular}

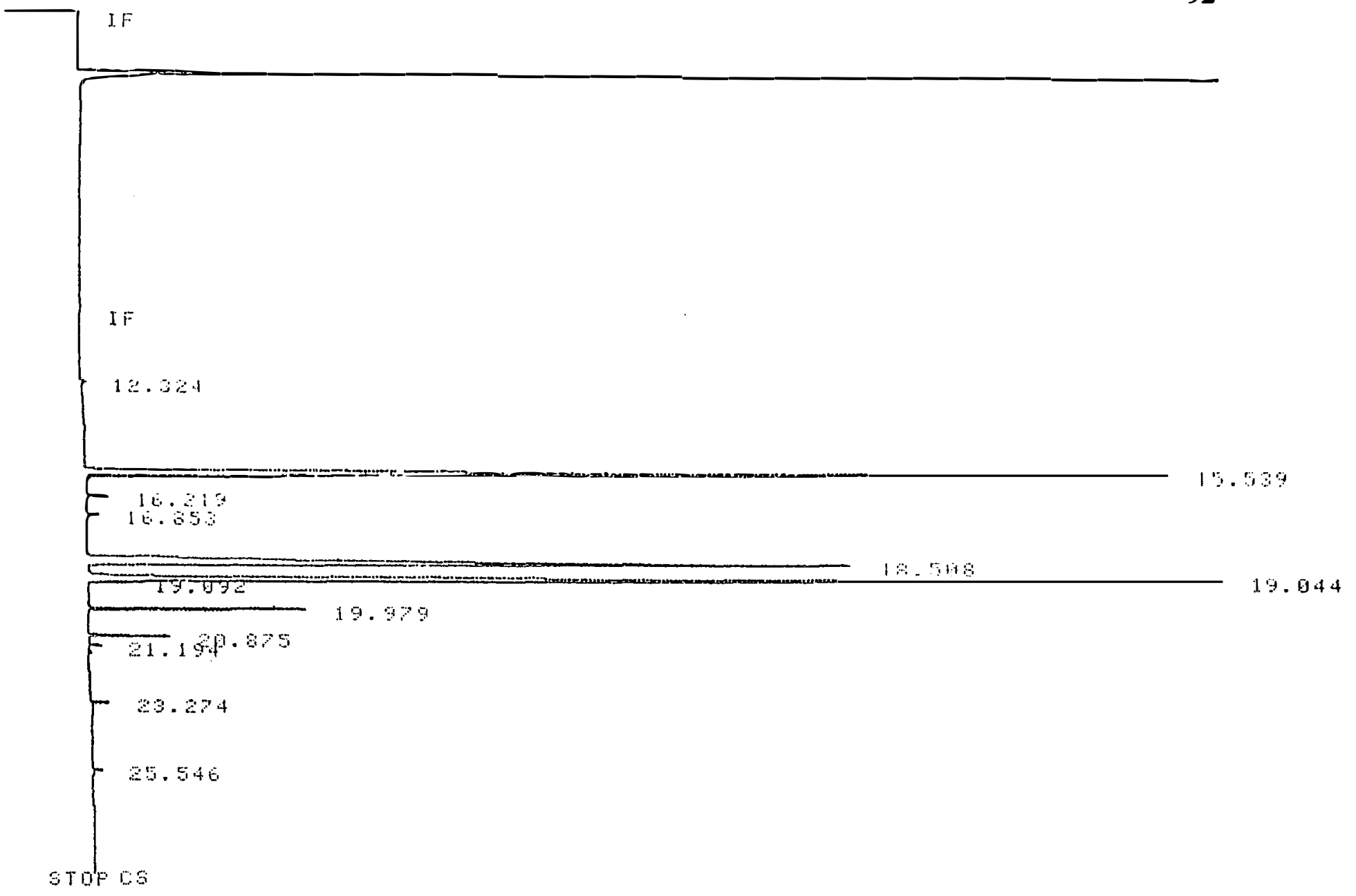

RUH\# 67 DEC 5. 1995 16:5013

SAMPLEH

WF 6 ,

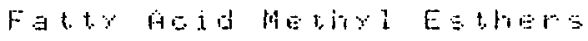

HOEH-AFEA

\begin{tabular}{|c|c|c|c|c|c|c|c|}
\hline $\mathrm{RT}$ & $T Y F E$ & $A F E A$ & H 1 प TH & i.te 11,01$\}$ & $\therefore 111$ & 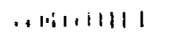 & Hanl \\
\hline 12,304 & LE: & $\because 8$ & $.11 \cdot 1: 3$ & $\cdot \cdots 1$ & : & . An. & $1.1: 11$ \\
\hline 15.599 & $\mathrm{FE}$ & 560569 & $.10 i$ & $5469 \%$ & $\therefore$ & $\therefore 45$ & 1. $6: 1$ \\
\hline 16.219 & $F E$ & 8191 & .0 .41 & 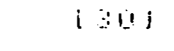 & $\therefore$ & $a$ & $16: 1$ \\
\hline 16.853 & $F E$ & 165 & .041 & 268 & 4 & .157 & $15: 2$ \\
\hline 18.503 & $\mathrm{EE}$ & 347790 & .136 & $4=718$ & 9 & $\therefore 491$ & $10: 1$ \\
\hline 19.044 & $F y$ & 408060 & .160 & 64273 & $\therefore \theta$ & $2+.605$ & $10: 1$ \\
\hline 19.972 & $\because E$ & 4354 & .032 & 229 & & .010 & \\
\hline 19.979 & FE: & 36960 & . $-1+1$ & $12+9$ & $\because$ & $\therefore .68$ & $10: 2$ \\
\hline 20.975 & $P E$ & 12.23 & .642 & 4858 & $\theta$ & 1.62 & $\because 6: 1$ \\
\hline 21.194 & $\mathrm{FB}$ & 1935 & .0141 & $\because y$ & $\because$ & .104 & $\because 6: 1$ \\
\hline 23.274 & $\mathrm{E}: \mathrm{E}$ & 2451 & .137 & 1112 & 13 & . & $22:$ \\
\hline 25.545 & $\mathrm{FE}$ & 1567 & .042 & $01 \%$ & $i \because$ & -132 & $z+4 \leq 0$ \\
\hline
\end{tabular}

TOTHL HREA = 118355

MUL FACTOK $=1$. DOBOE + GB 


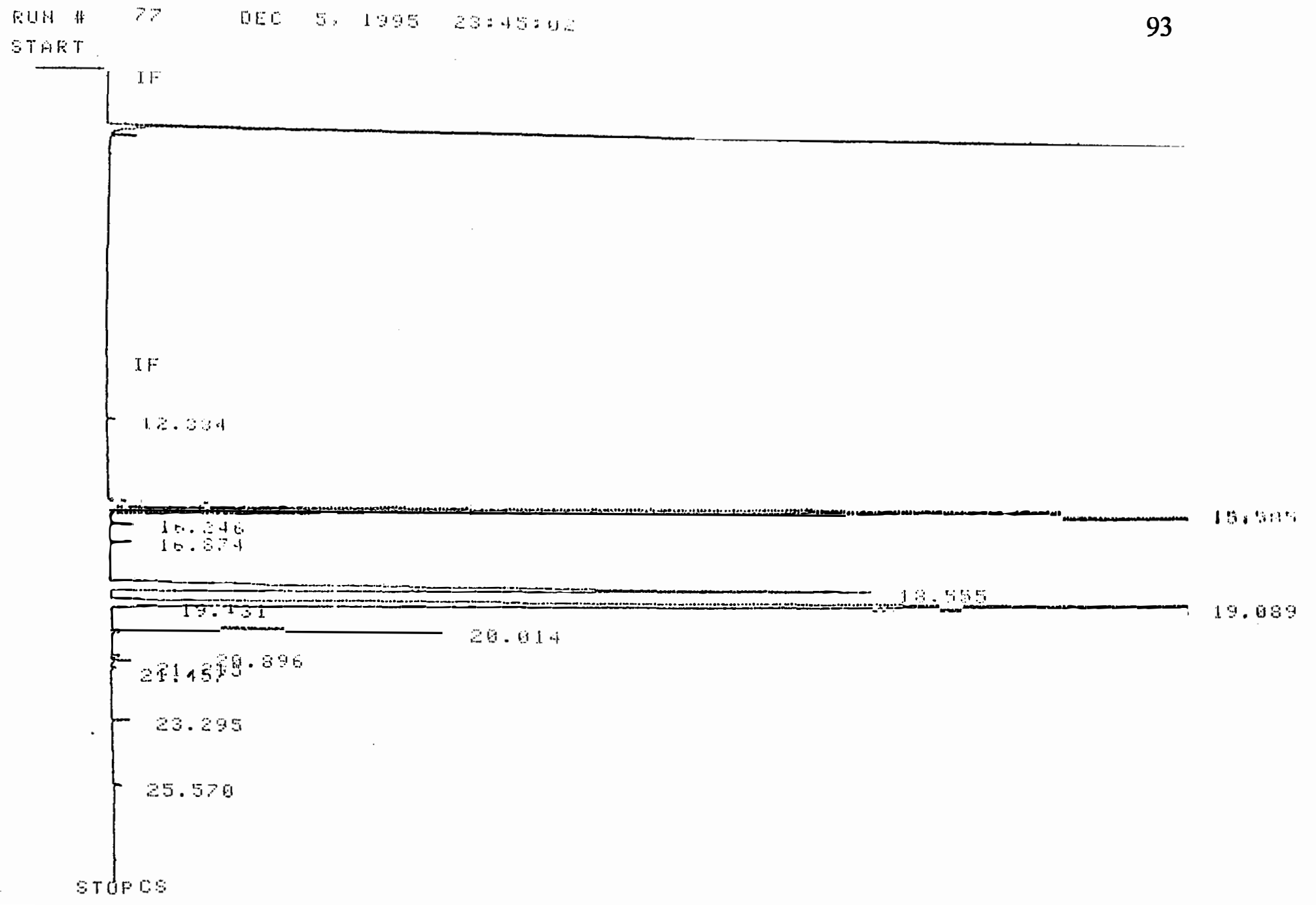

FUH:

OEE $\because=\quad 1995 \quad 29+5=02$

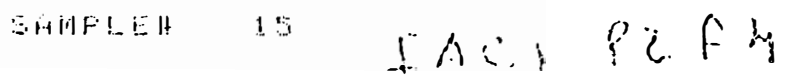

Fat. Heid Hethyl Esthers

MUEM-AिEEA

\begin{tabular}{|c|c|c|c|c|c|c|c|}
\hline $\mathrm{E} T$ & TYPE & $A F E A$ & WICTH & HES S H T & C.111. 11 & rillill11T & H!nil: \\
\hline 12.334 & $\mathrm{FE}$ & 167 & $.13+5$ & $\because \mathrm{i}$ & $i$ & $.11=$ & $14: n$ \\
\hline 15.565 & $F E$ & 46393 & .113 & 71923 & 2 & 32.152 & $10: 0$ \\
\hline 1. 6.246 & $F E:$ & 3546 & $.0+2$ & $\mathrm{i}+\mathrm{z} \mathrm{j}$ & $\overline{3}$ & .240 & $16: 1$ \\
\hline 15.874 & $F E:$ & 2560 & .045 & $131 \%$ & 4 & $.2+3$ & $16: 2$ \\
\hline 1.5 .555 & $F \cdot E$ & 377268 & .146 & +5035 & $5 \%$ & 25.511 & $15: 0$ \\
\hline 19.989 & $E \psi$ & 525660 & .119 & 7060 & $\dot{\theta}$ & 35.680 & $10: 1$ \\
\hline 19.131 & $Y E$ & 4510 & .026 & 2639 & & .060 & \\
\hline 20.914 & $F E$ & 52060 & .044 & 19990 & 7 & 3.55 & $10: 2$ \\
\hline 29.896 & $\mathrm{EE}$ & $1225+$ & .642 & +89 & 6 & $.93 a$ & $24: 0$ \\
\hline 21.215 & $E: E$ & 2951 & .041 & 2144 & 9 & $=200$ & $20: 1$ \\
\hline 21.457 & $E \mathrm{E}$ & 770 & .544 & $2=1$ & ia & .553 & $10: 9$ \\
\hline 23.295 & $F E$ & 2598 & .039 & 1102 & $i$ & .178 & $22: 0$ \\
\hline 25.570 & $E E:$ & 1565 & .949 & 580 & 12 & $.10 E$ & $24: 0$ \\
\hline
\end{tabular}

TOTAL AREA $=1477578$

MUL FACTOE=1. THB日E + BO 
EUN \# 79 DEE 6.1995 प9:20:16

STAF: T

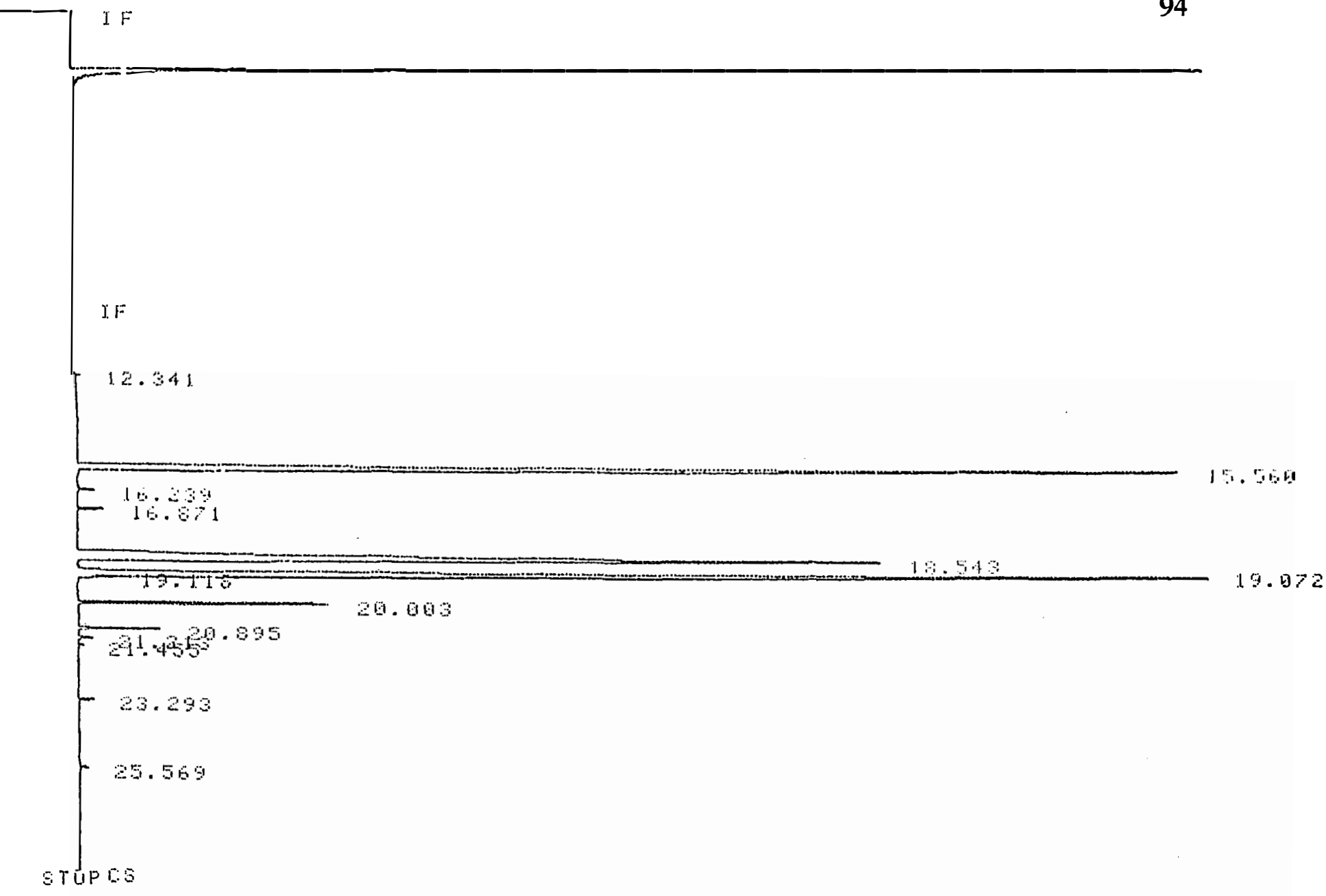

FUHA 79 LED 6. 1995 69:26:13

SHPLEH IO

If $667 \% 2.61$

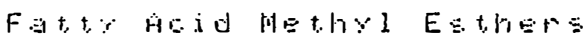

\begin{tabular}{|c|c|c|c|c|c|c|c|}
\hline \multicolumn{8}{|c|}{ DRH-AFEA } \\
\hline$F T$ & $T Y F^{\prime} E$ & APEEH & WI I TH & $111: \mid i, 1 ! 1$ & $1,111.11$ & 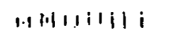 & 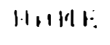 \\
\hline 12.341 & $E E$ & 736 & $.612:$ & 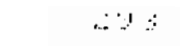 & $i$ & $.119:$. & $14: u$ \\
\hline 15.560 & $\mathrm{FE}$ & 374984 & .106 & $62+59$ & $\ddot{z}$ & $\therefore 96 y$ & $16=6$ \\
\hline 26.239 & $Y E$ & 2714 & .541 & 1002 & 3 & .214 & $16: 1$ \\
\hline 16.671 & $F E:$ & 4150 & .944 & 1508 & 4 & .239 & $15: 2$ \\
\hline 18.545 & FE: & 382276 & .141 & 45278 & $G F$ & $30.18 \mathrm{z}$ & $1 \mathrm{~B}: 9$ \\
\hline 19. 972 & $\mathrm{EY}$ & 447572 & .110 & 57589 & $E R$ & 35.314 & $18: 1$ \\
\hline 13.110 & $Y \mathrm{E}$ & 3952 & .931 & $215: 4$ & & .060 & \\
\hline 20.013 & $Y \mathrm{~B}$ & 36016 & .042 & 14392 & 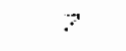 & $\approx .041$ & $18: 2$ \\
\hline 29.695 & $\mathrm{E}: \mathrm{E}$ & 11811 & .041 & 4649 & 3 & .932 & 2日: \\
\hline 21.213 & $\mathrm{EE}$ & 2346 & $.5+2$ & 924 & 9 & .105 & $20: 1$ \\
\hline 21.455 & $E F$ & 980 & $.9+6$ & 317 & 16 & .070 & $15: 3$ \\
\hline 23.293 & $F E$ & 2335 & .939 & 990 & 11 & .134 & $28: 0$ \\
\hline 25.569 & $\mathrm{EE}$ & 1582 & .046 & 540 & 1. & .124 & $2+10$ \\
\hline
\end{tabular}




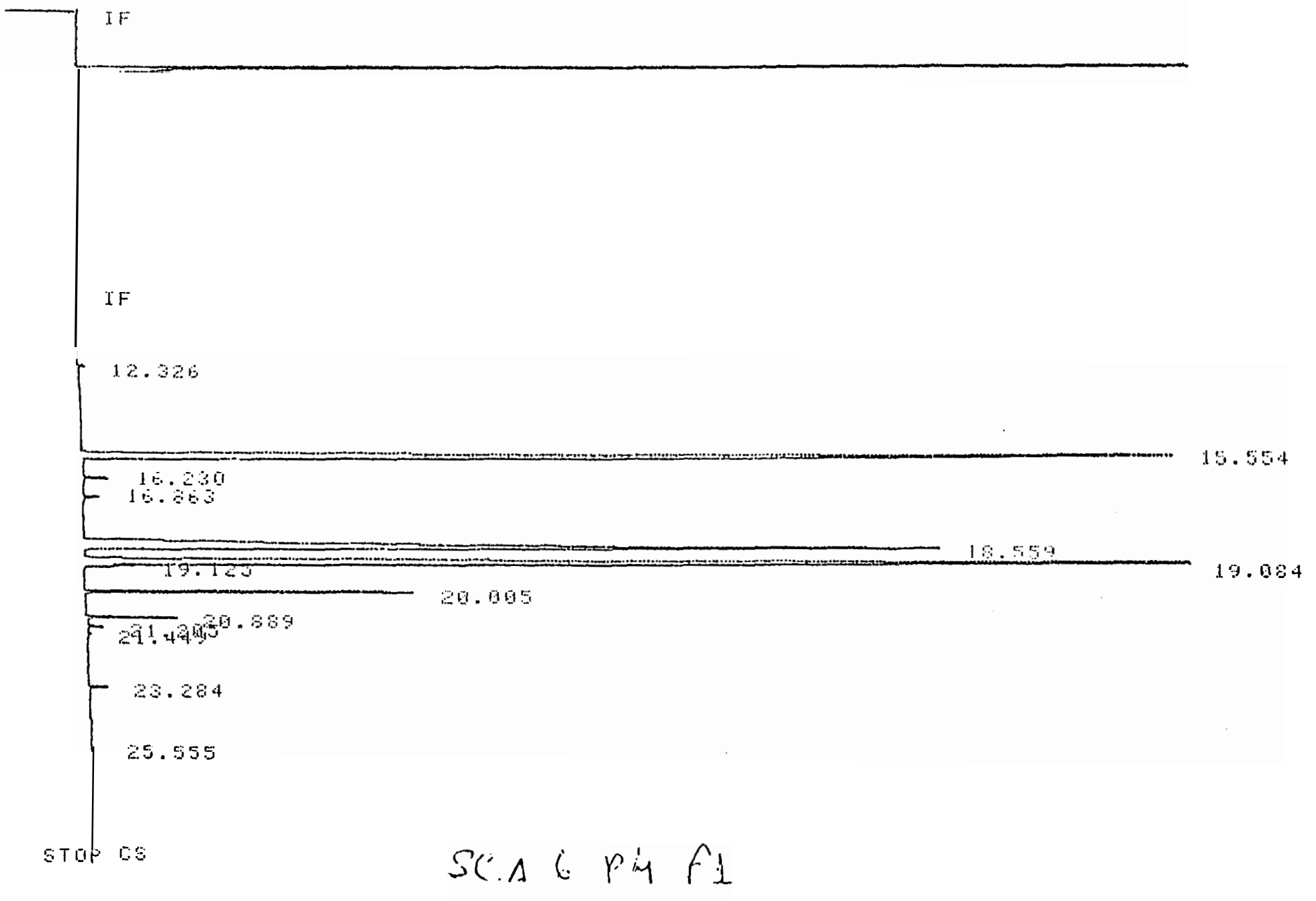

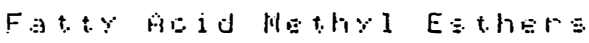

HDFH-HFEA

\begin{tabular}{|c|c|c|c|c|c|c|c|}
\hline$F: T$ & TUFE & APEA & WIOTH & HE J B. :T & EHIL & HAromt & HAHE: \\
\hline 12.326 & $P E$ & 105 & . B & $1, \cdots$ & 1 & $.11 \cdot \cdot \cdot 1$ & $1.1: 1: 1$ \\
\hline 15.554 & $F E$ & 387999 & .193 & 6360 & 2 & $\therefore .13$ & $16: 0$ \\
\hline 15.230 & $F E$ & 3980 & .642 & $15: 1$ & $\because$ & .278 & $1 E: 1$ \\
\hline 16.963 & $\mathrm{FE}$ & 2315 & .046 & 1011 & 7 & .197 & $15: 2$ \\
\hline 16.559 & $F E$ & 435929 & .140 & 4931 & $5 F$ & 90.546 & $18: 0$ \\
\hline 19.584 & EV & $5245+5$ & .120 & 75048 & 6 & 56.756 & $18: 1$ \\
\hline 19.125 & $\forall E$ & 5261 & .929 & 3069 & & . 050 & \\
\hline 20.905 & $P E$ & 49902 & .044 & 19129 & $\vec{r}$ & 3.509 & $13: 2$ \\
\hline 20.599 & $\mathrm{BE}$ & 13371 & $.94 i$ & 5259 & $\theta$ & .95 & $20: 9$ \\
\hline 21.205 & $\mathrm{EE}$ & 257 & - 941 & 1009 & 9 & .180 & $20: 1$ \\
\hline$\because 1.449$ & 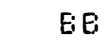 & 834 & .645 & 310 & 10 & .059 & $10: 3$ \\
\hline 23.284 & $F E$ & 2587 & .637 & 1. $1 \div 0$ & 11 & .181 & $22: 0$ \\
\hline 25.555 & EE & 1494 & .040 & 615 & $1 \%$ & .104 & $24: 0$ \\
\hline
\end{tabular}

TDTAL AREA $=14324$ GT

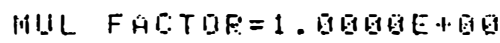




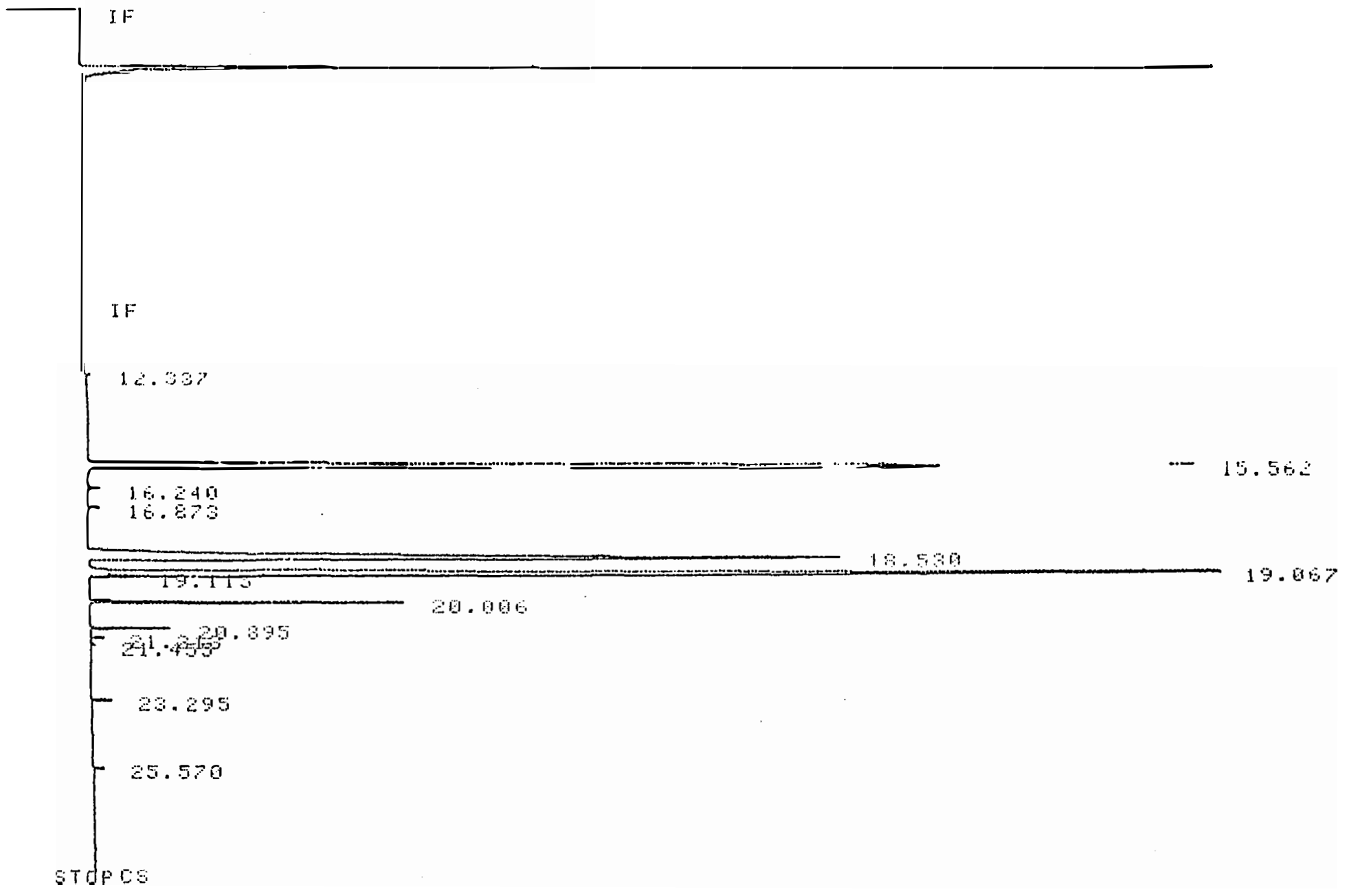

$$
\begin{aligned}
& \text { RUHA To [EE 5. } 1995 \text { 21:06:24 }
\end{aligned}
$$

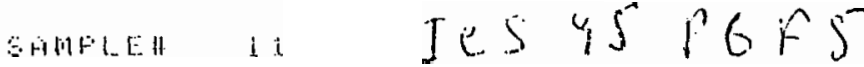

Fat.ty Hed Methyl Esthers.

IIIERI-HPEA

\begin{tabular}{|c|c|c|c|c|c|c|c|}
\hline$ß T$ & T & HWLH & HIOH & $|11| 1,.11 \mid$ & 1.11111 & 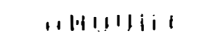 & Hнlli. \\
\hline 12.37 & $\mathrm{EE}$ & 951 & .545 & $3+1$ & $i$ & $.0 \%$ & $i+i: 1$ \\
\hline 15.562 & $E: 8$ & 384528 & .103 & $z=2+21$ & 2 & 31.270 & $6: 0$ \\
\hline 16.240 & $E B$ & 1932 & .141 & 98 & 9 & $.15 \%$ & $16: 1$ \\
\hline 16.973 & $\ddot{F E}$ & 213 & .045 & 79 & 4 &.$\quad .23$ & $16: 2$ \\
\hline 18.590 & $E E$ & $3+4179$ & .154 & $4: 38$ & 58 & 27.65 & $15: 0$ \\
\hline 12.067 & $F$ & 434331 & .109 & 6.59 & 68 & 35.320 & $18: 1$ \\
\hline 19.115 & UE & 4705 & .031 & 256 & & .000 & \\
\hline 20.096 & $Y \mathrm{E}$ & 45834 & $.19+3$ & 1795 & $\eta$ & 5.771 & $18: 2$ \\
\hline 20.895 & $\mathrm{BE}$ & $1196 E$ & .641 & 4863 & 3 & .973 & $2 \dot{0}: \ddot{\theta}$ \\
\hline 21.213 & $F E$ & 2114 & .041 & 86 & 9 & .172 & $20: 1$ \\
\hline 21.455 & $\mathrm{BE}$ & 865 & .039 & 360 & 10 & .87 & $18: 3$ \\
\hline 23.295 & $F \cdot E$ & 2750 & .637 & 1227 & 11 & .23 & $22=9$ \\
\hline 25.570 & $\mathrm{FE}$ & $1 E 16$ & .948 & 869 & 12 & .131 & $24: 0$ \\
\hline
\end{tabular}




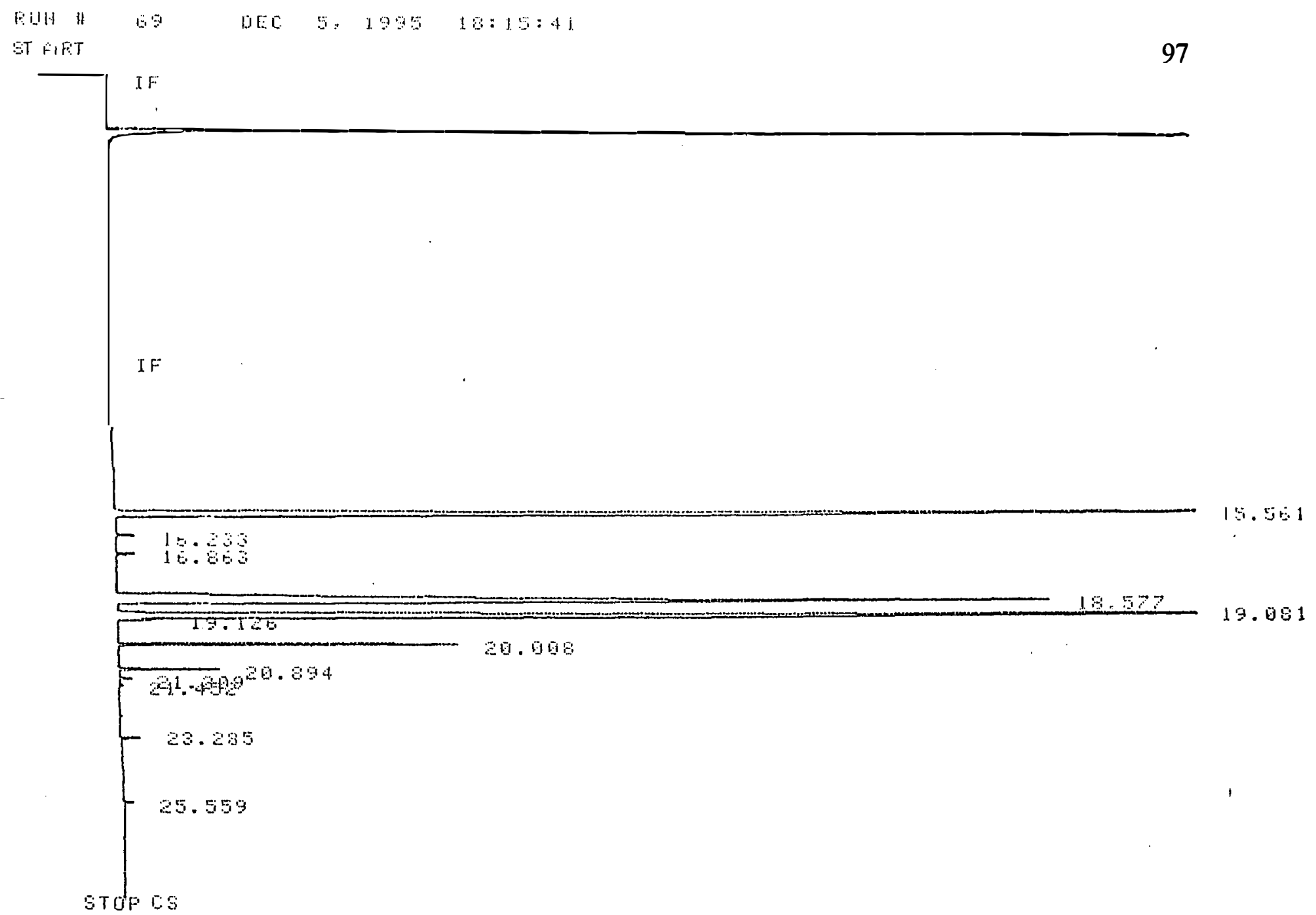

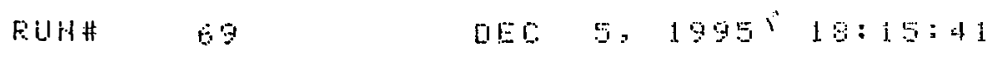

SAHFLEH

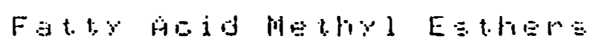

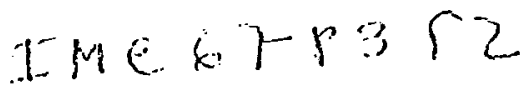

\begin{tabular}{|c|c|c|c|}
\hline \multicolumn{4}{|l|}{ HOFB-ÂEEA } \\
\hline Fit & $T \because F E$ & APEO & (i) $10 T H$ \\
\hline 15.561 & $E E$ & $4 i s 7 i$ & .105 \\
\hline 16.283 & $P E$ & 3104 & .943 \\
\hline 16.863 & $F \cdot E$ & 3019 & -946 \\
\hline 13.577 & $P E$ & 521472 & .157 \\
\hline 19.981 & E: $y$ & 491622 & .119 \\
\hline 19.126 & $Y E$ & 5069 & .038 \\
\hline 20.068 & $V E$ & 52689 & .943 \\
\hline 20.694 & $\mathrm{EE}$ & 15710 & .845 \\
\hline 21.209 & $\mathrm{EE}$ & 2096 & .043 \\
\hline 21.452 & $\mathrm{FE}$ & 764 & .949 \\
\hline 23.285 & $\mathrm{EE}$ & 2793 & .038 \\
\hline 25.559 & $\mathrm{BE}$ & 1690 & .045 \\
\hline
\end{tabular}

\begin{tabular}{|c|c|}
\hline $111: 11.111$ & $i, \ldots l . \|$ \\
\hline $6+105$ & $\therefore$ \\
\hline 1132 & 3 \\
\hline 1. $\because 11$ & it \\
\hline 55198 & $5 \mathrm{p}$ \\
\hline 69596 & 68 \\
\hline 2530 & \\
\hline 20243 & $?$ \\
\hline 6092 & $\because$ \\
\hline $31 !$ & 9 \\
\hline 250 & 10 \\
\hline 1220 & 11 \\
\hline 520 & $1:$ \\
\hline
\end{tabular}

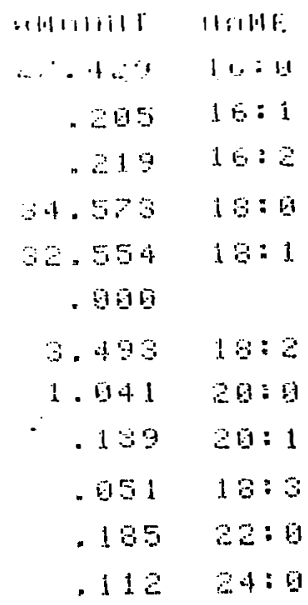

TOTHL AREA $=1513441$

MIIL. FAC:TOE = 1. BOBEE + DO 


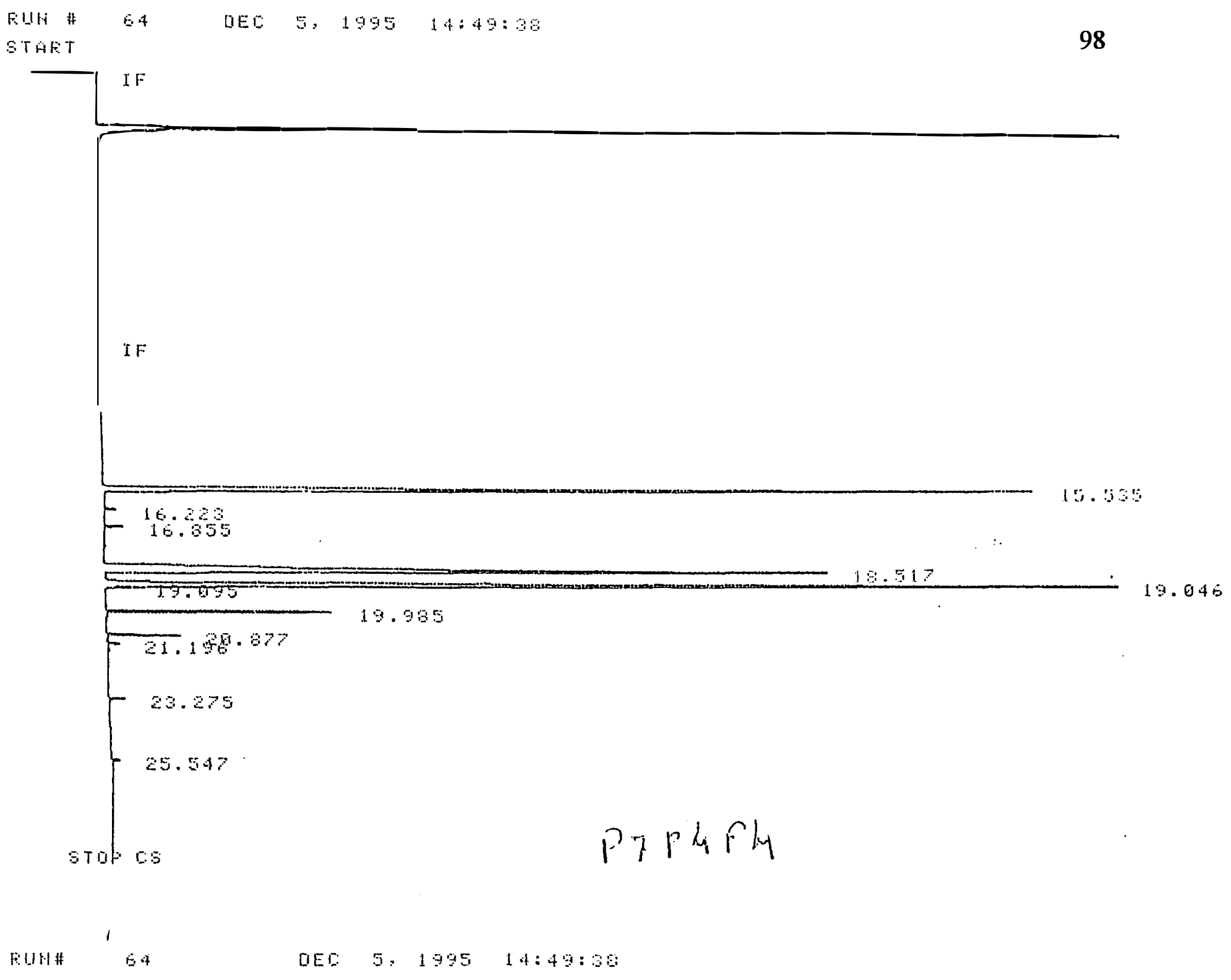

\section{SAMF̈LE\# Q}

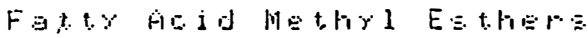

HOEH-HFH

\begin{tabular}{|c|c|c|c|c|c|c|c|}
\hline 101 & ГテคE & HEEH & 以 Ј & $111 . .11,111$ & 11111 & $1,1+1,11111$ & $\|$ 11, ll. \\
\hline 15.55 & $F E$ & 394503 & .696 & 58136 & $\therefore$ & $\therefore 6.60$ & $1 t .: 1$ \\
\hline 18.223 & $F \cdot E$ & 2234 & .042 & 88 & 3 & .191 & $16: 1$ \\
\hline $1 \dot{6} .95$ & $P E$ & 3415 & .1943 & 1320 & 4 & .291 & $16: 2$ \\
\hline 18.517 & $P B$ & 372064 & .138 & 45975 & 58 & 31.795 & $18: 0$ \\
\hline 19.946 & $8 \%$ & 404114 & . 156 & 63990 & $\Delta f$ & 34.535 & $1: 1$ \\
\hline 19.095 & WE & 3152 & .532 & 1631 & & .013 & \\
\hline 19.985 & Ve & 35864 & .042 & 14341 & 7 & 3.064 & $18: 2$ \\
\hline 20.677 & $F E$ & 12051 & .941 & 4845 & 8 & 1.550 & $20: 0$ \\
\hline 21.196 & $P E$ & $2 こ 1 日$ & .642 & 975 & 9 & .159 & $20: 1$ \\
\hline 23.275 & $\mathrm{EE}$ & $23+5$ & .037 & 1858 & 11 & .200 & $22: 0$ \\
\hline 25.547 & $\mathrm{FB}$ & 1.495 & .644 & 539 & 12 & - 1.20 & $24: 0$ \\
\hline
\end{tabular}




\section{APÊNDICE 2}

Perfis cromatográficos dos triacilgliceróis dos dez genótipos estudados, obtidos pela técnica de Cromatografia Gasosa Capilar. Cada cromatograma corresponde à análise das sementes de um único fruto. 


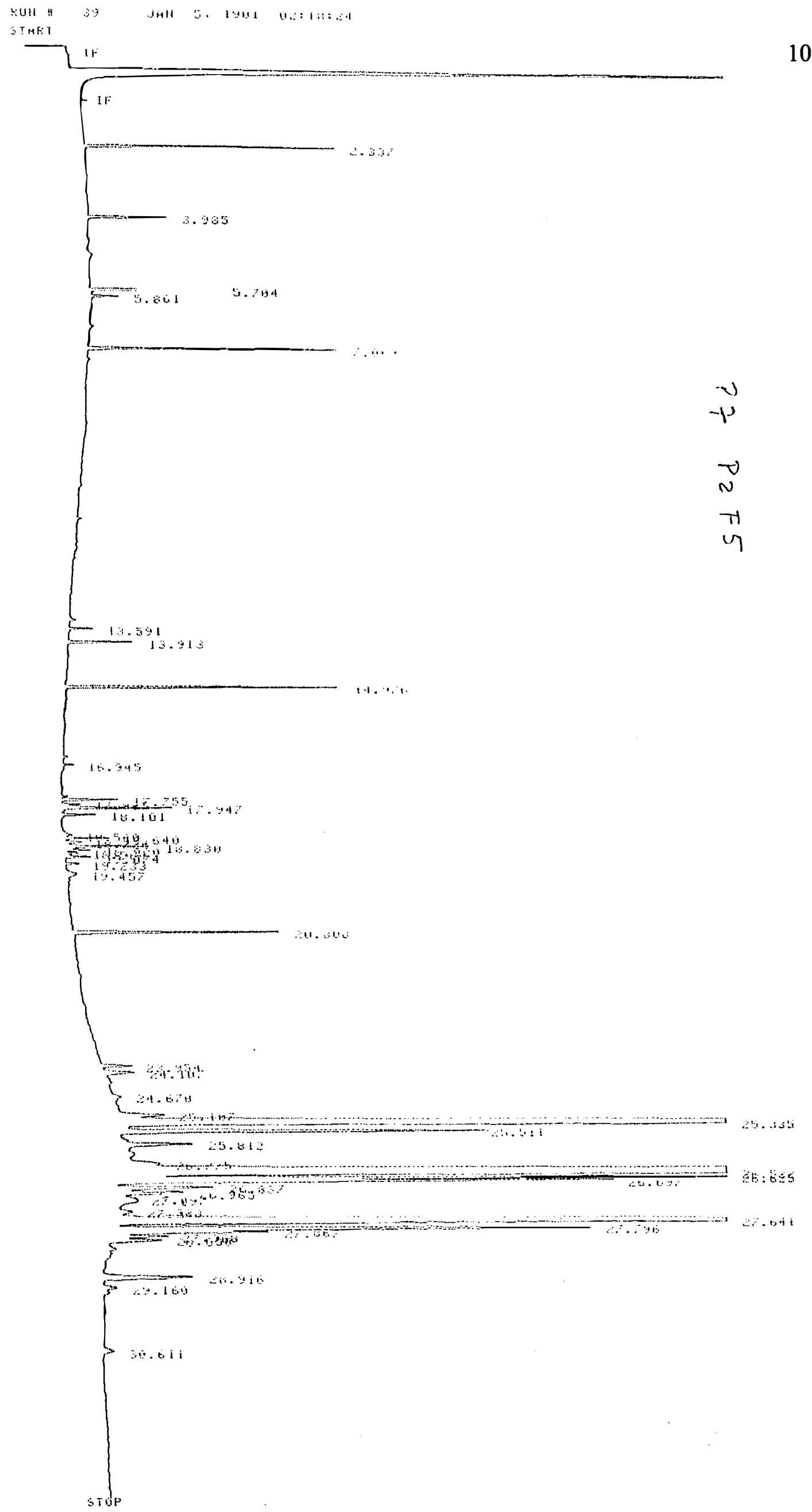




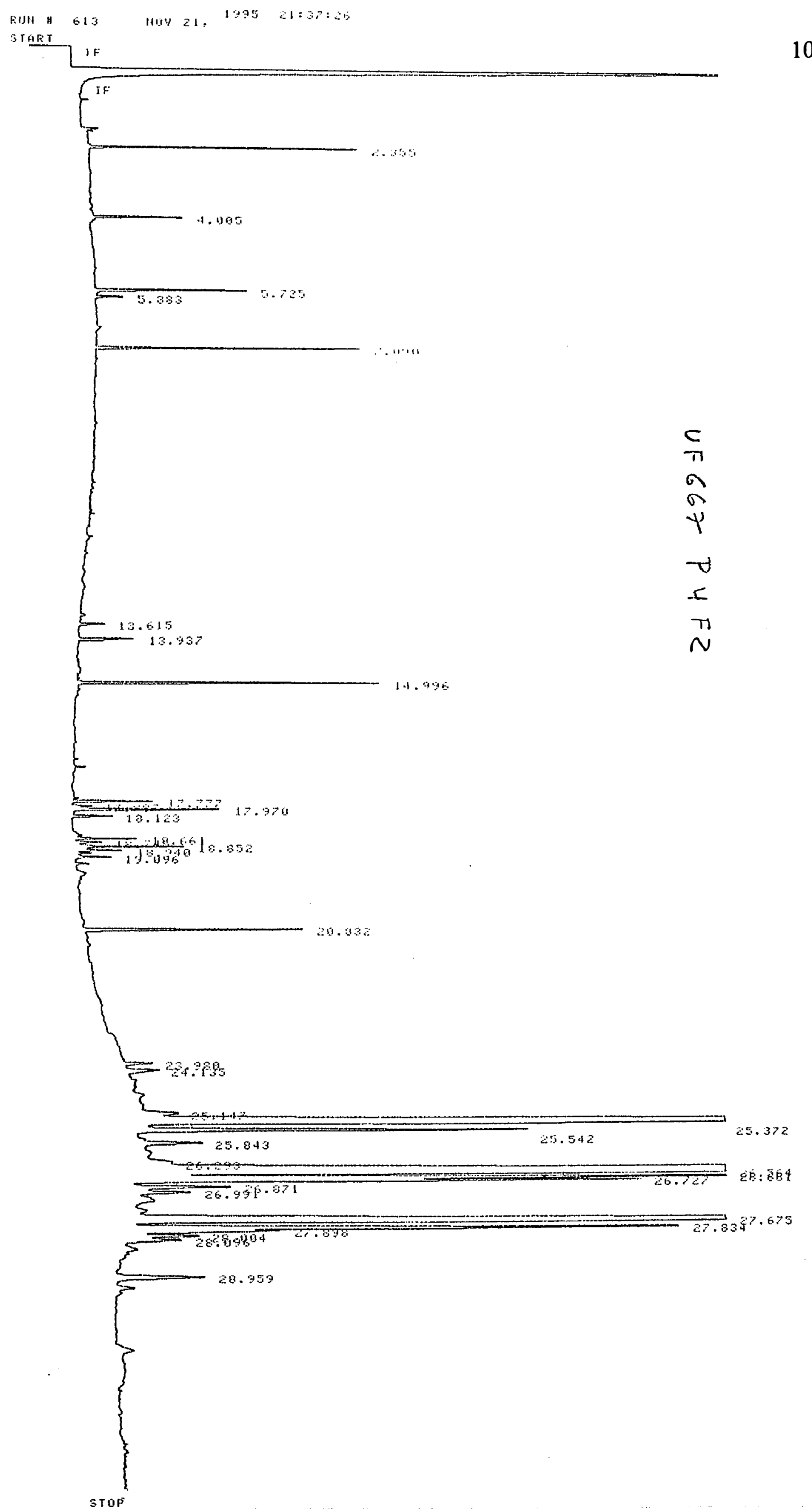


:*) StE STHET

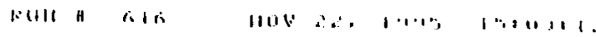

STAET

\II

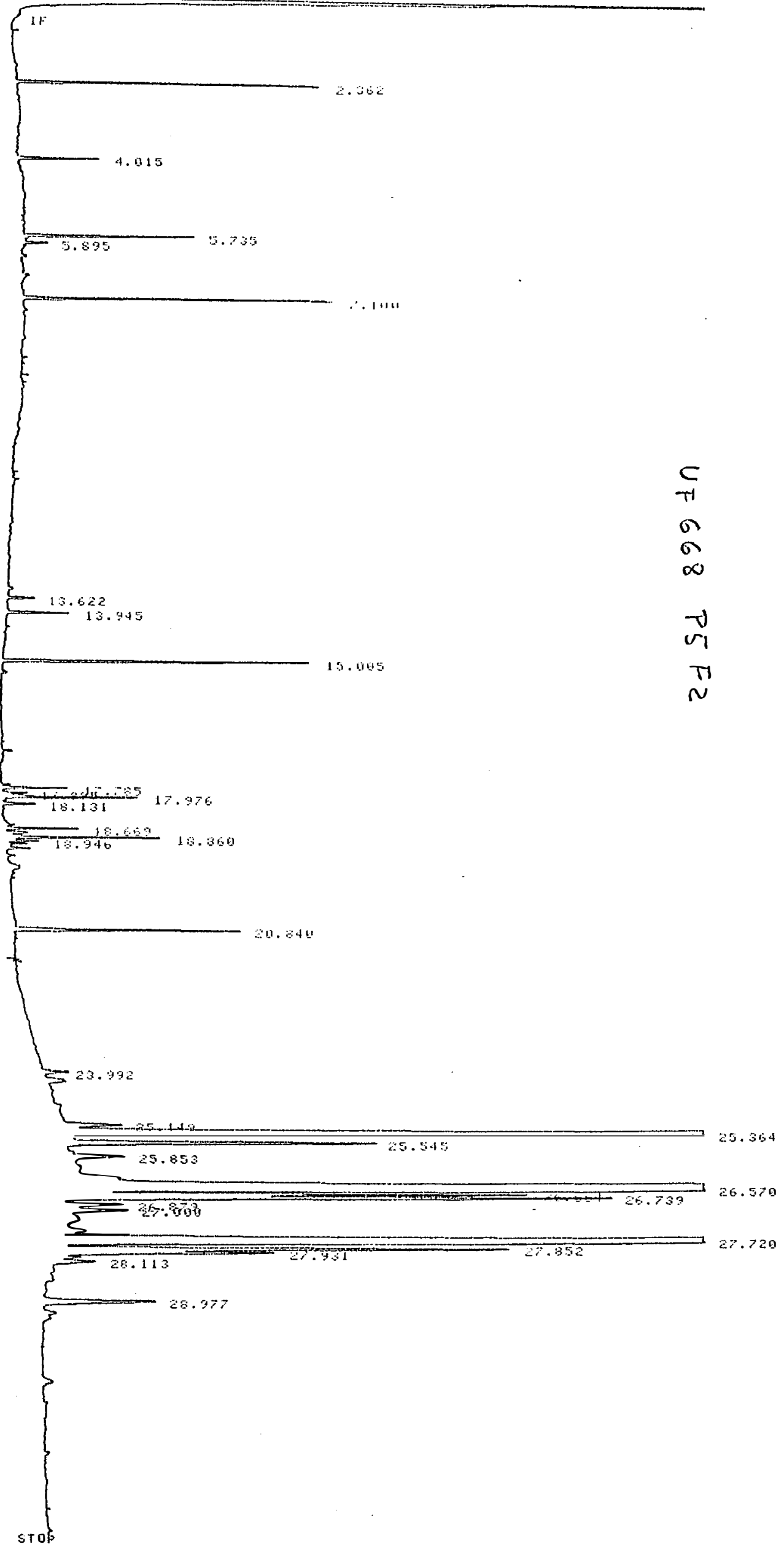




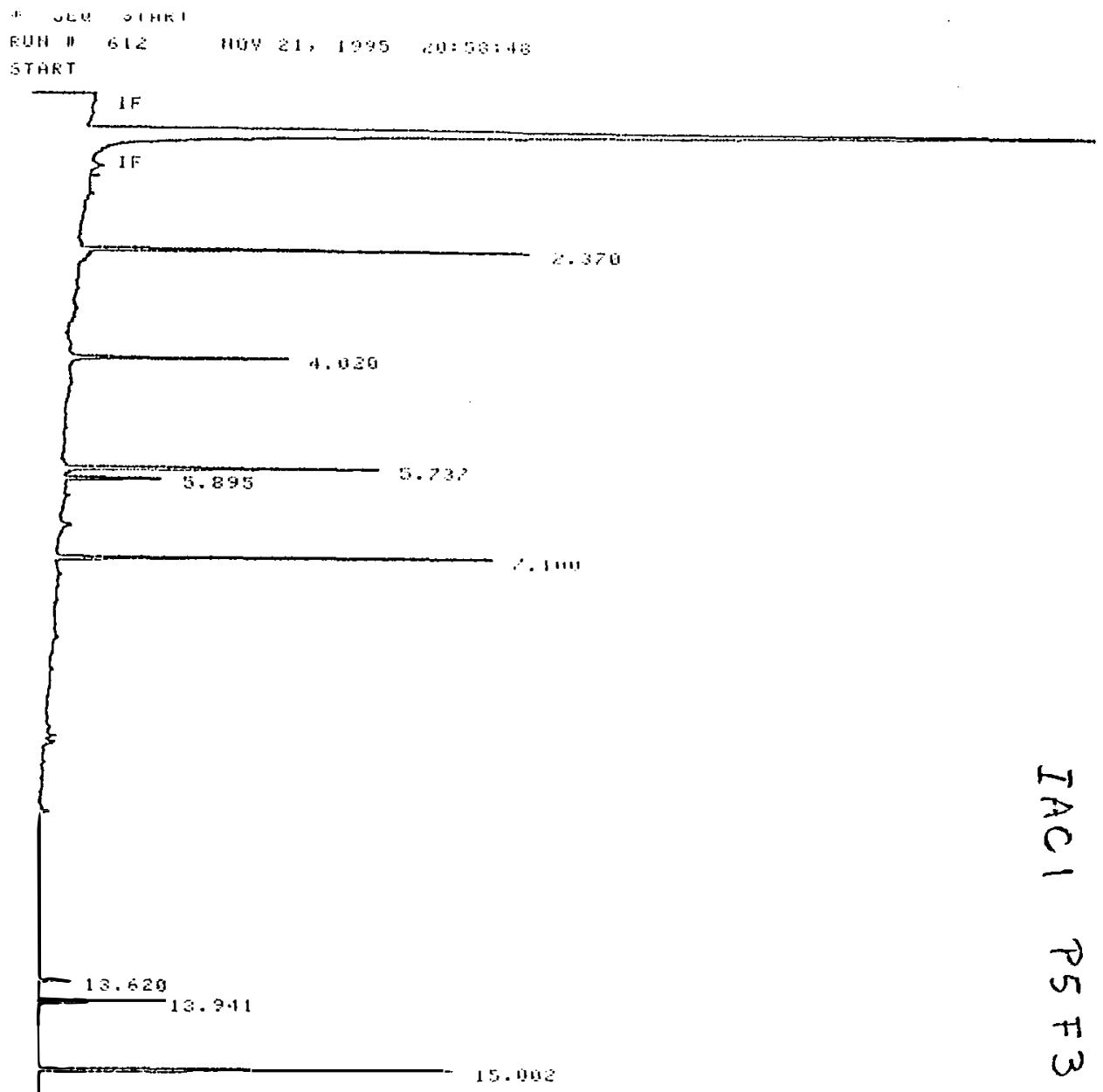

$\overrightarrow{0}$

$\nabla$

$\pi$

$\omega$

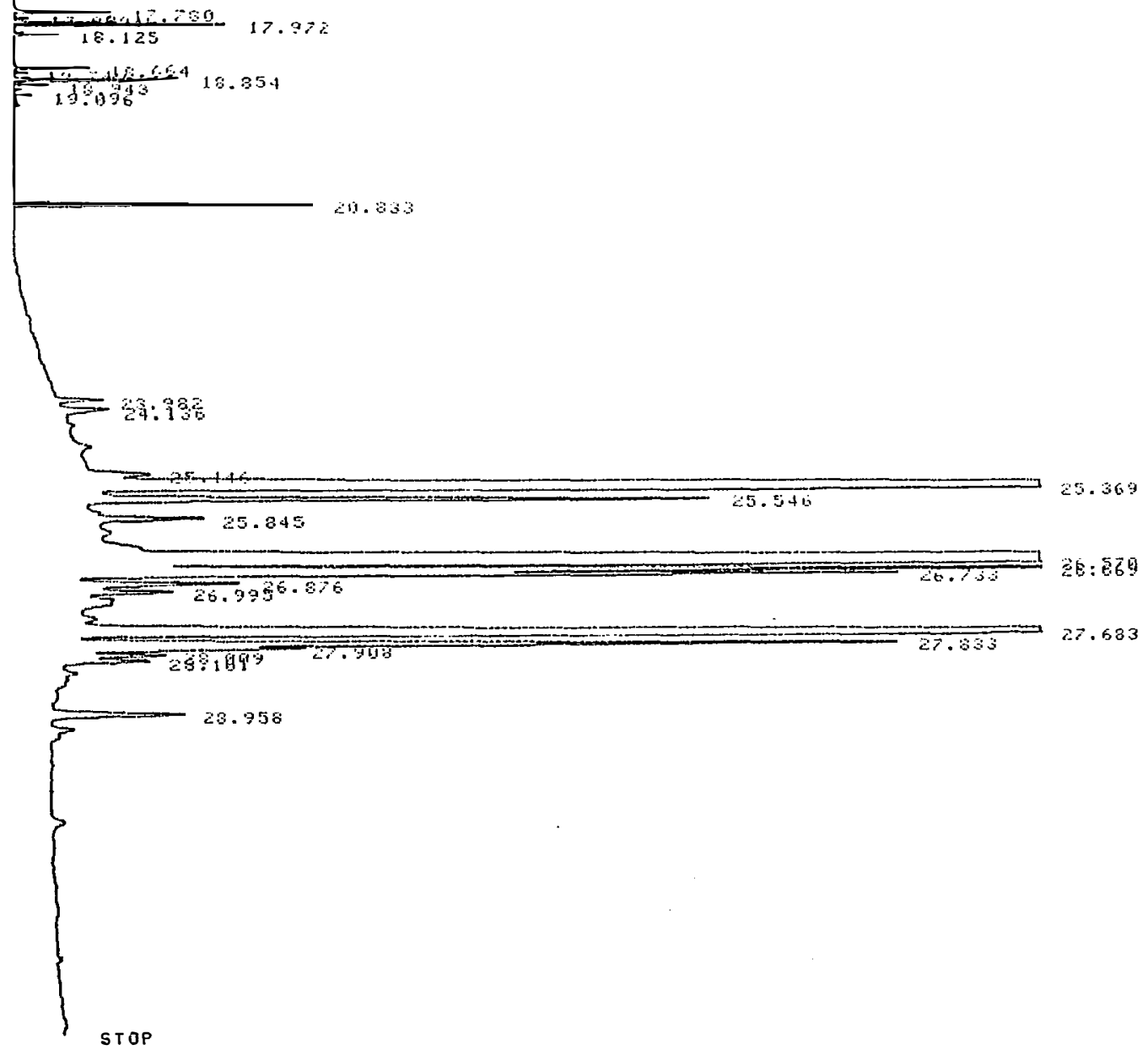




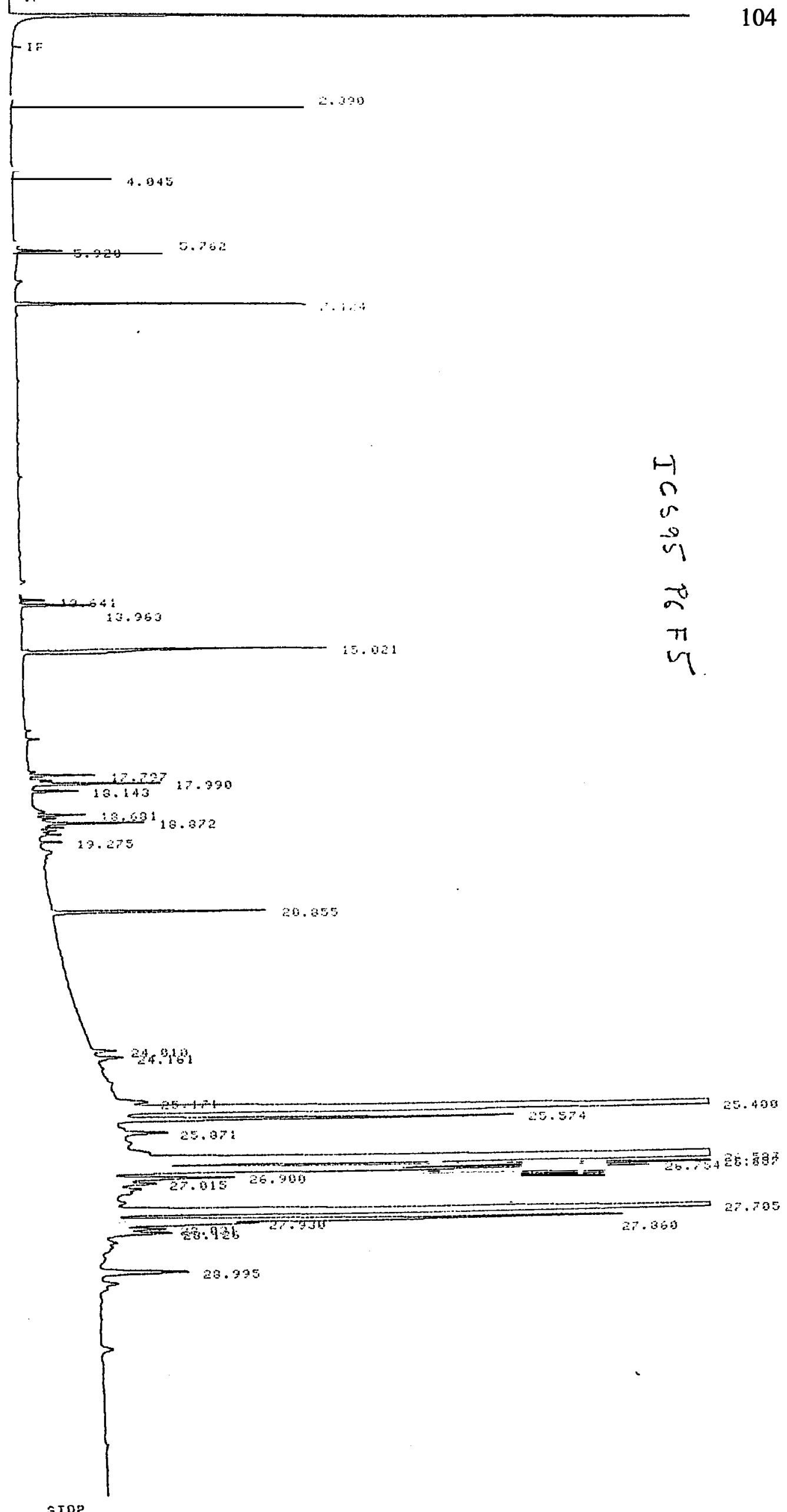




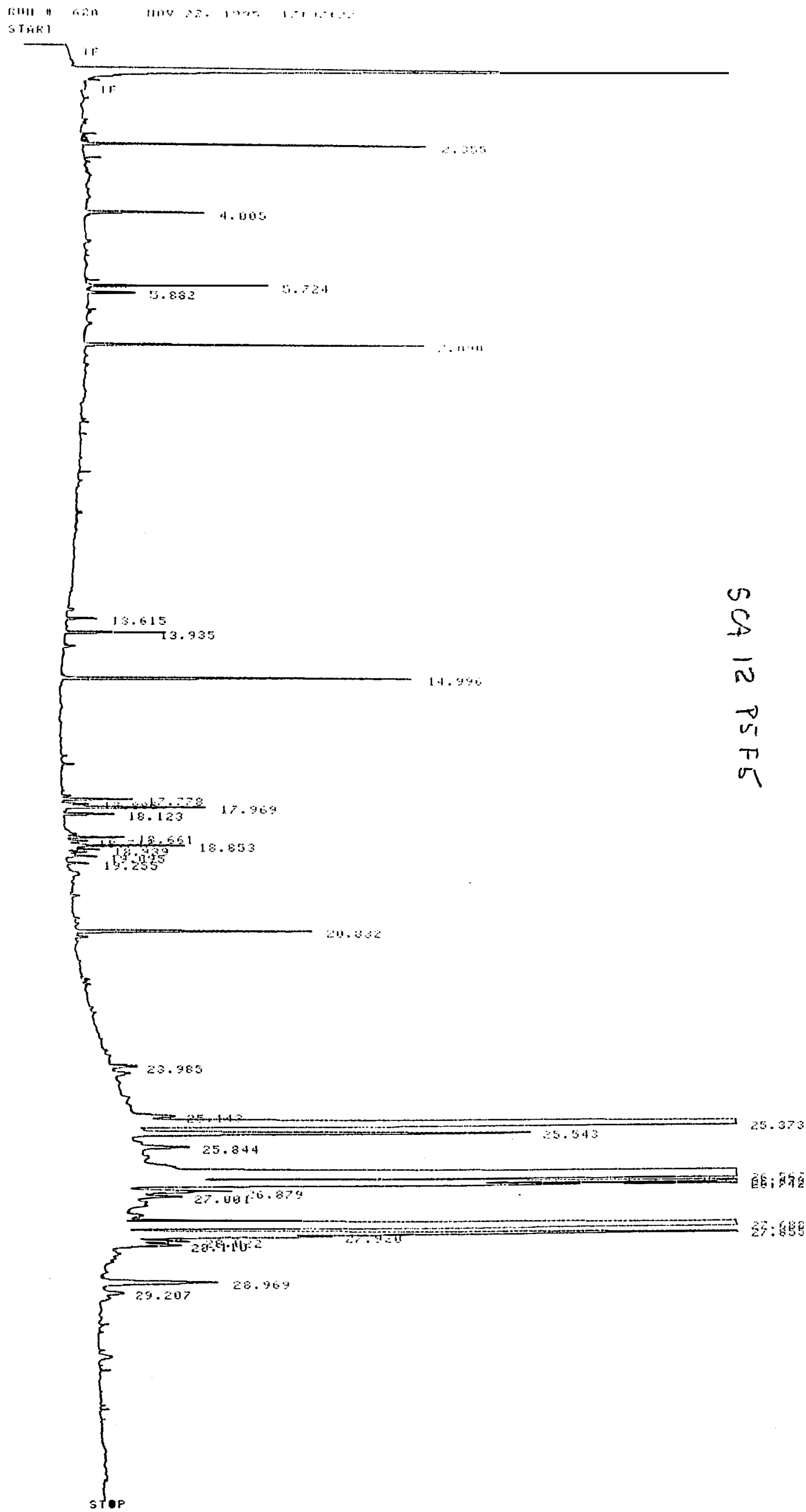




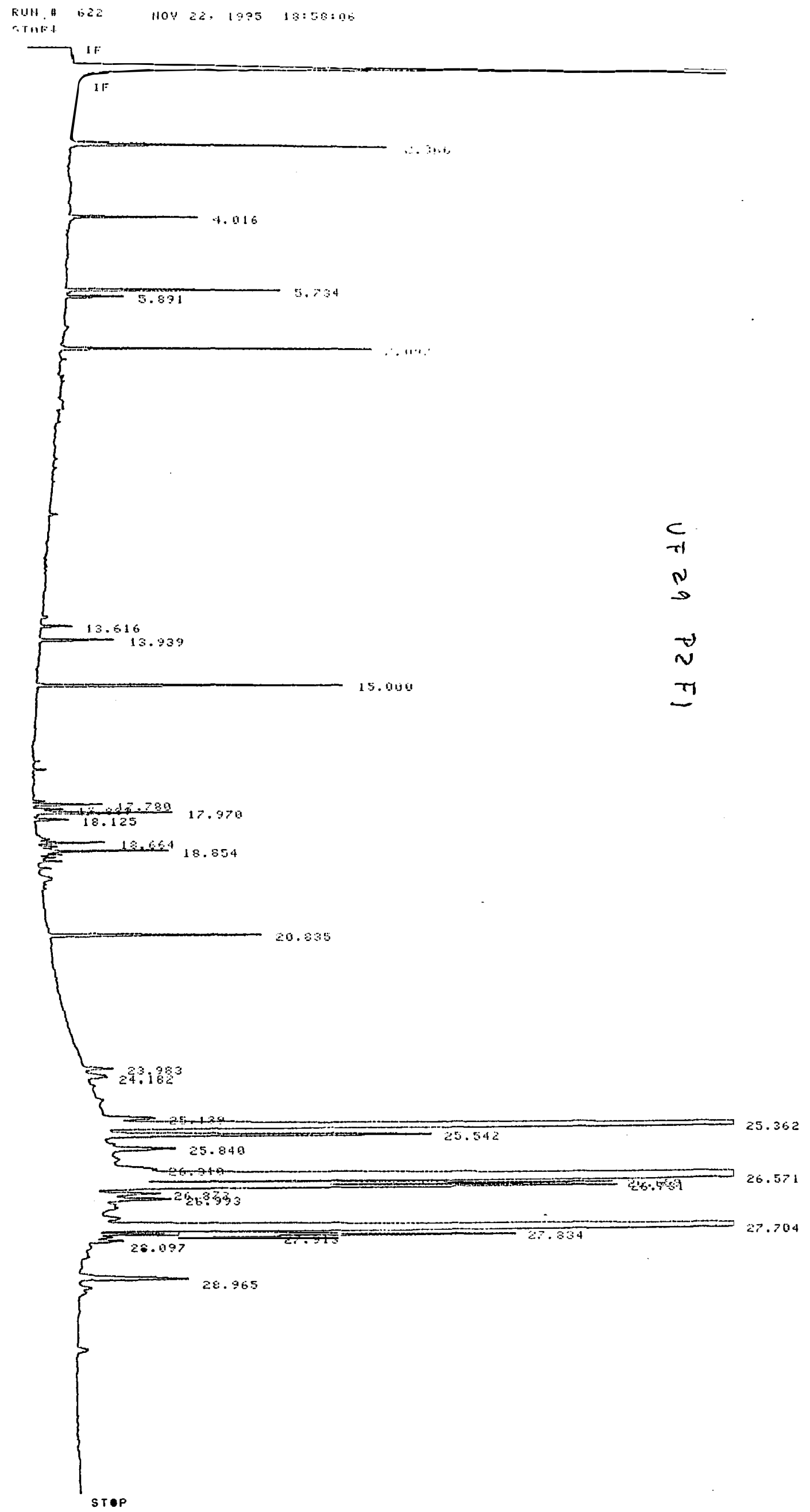




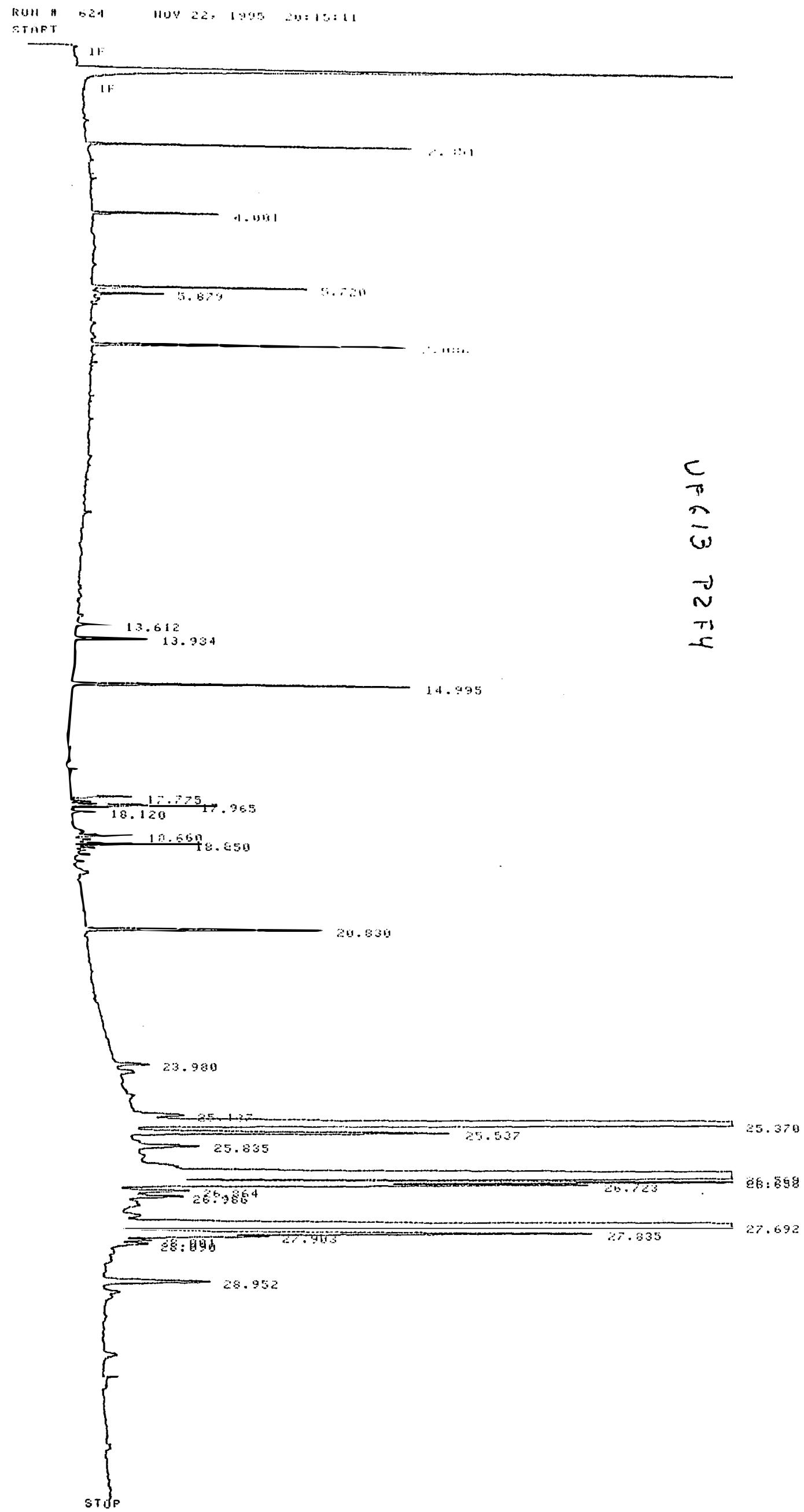




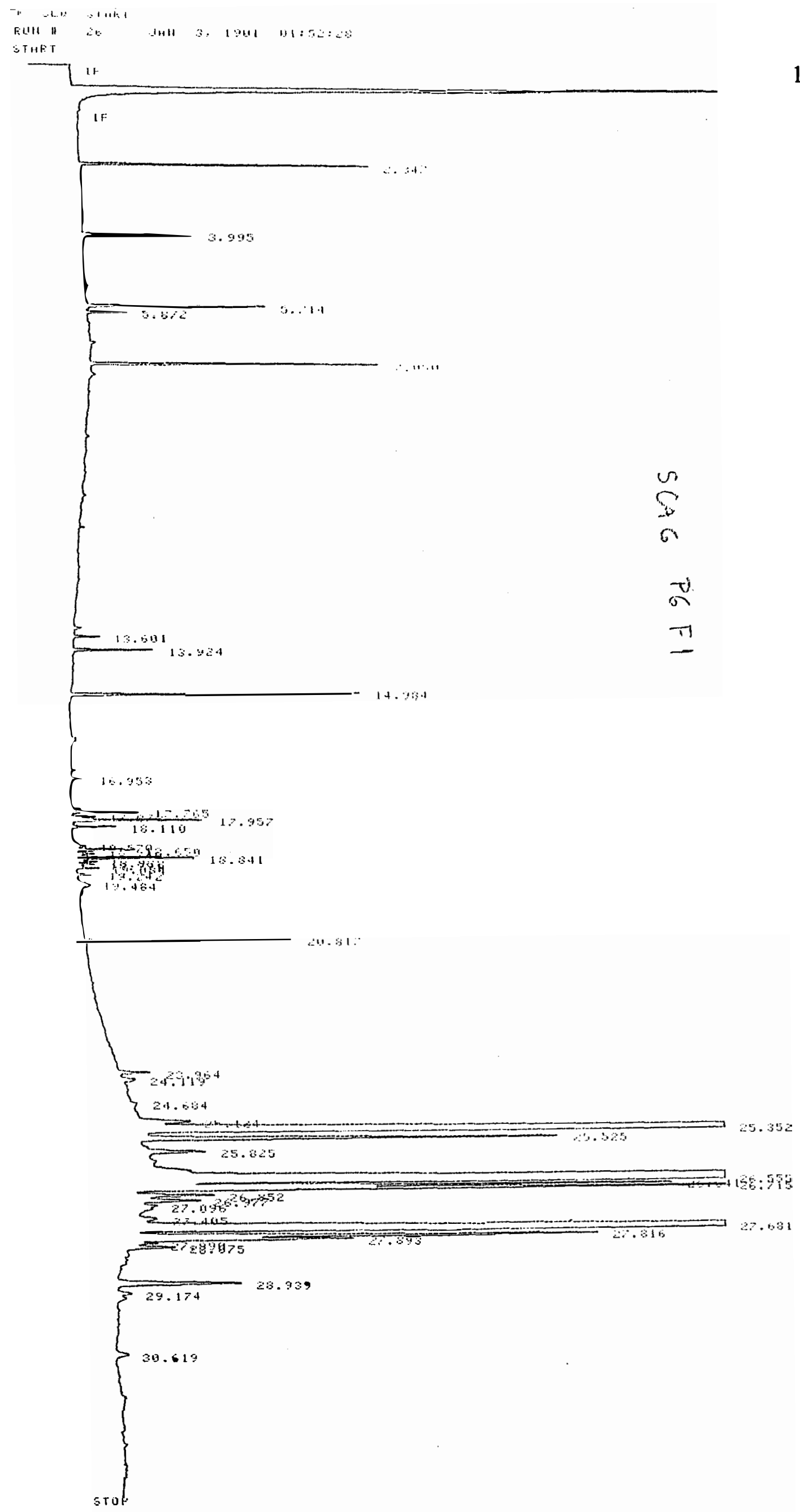




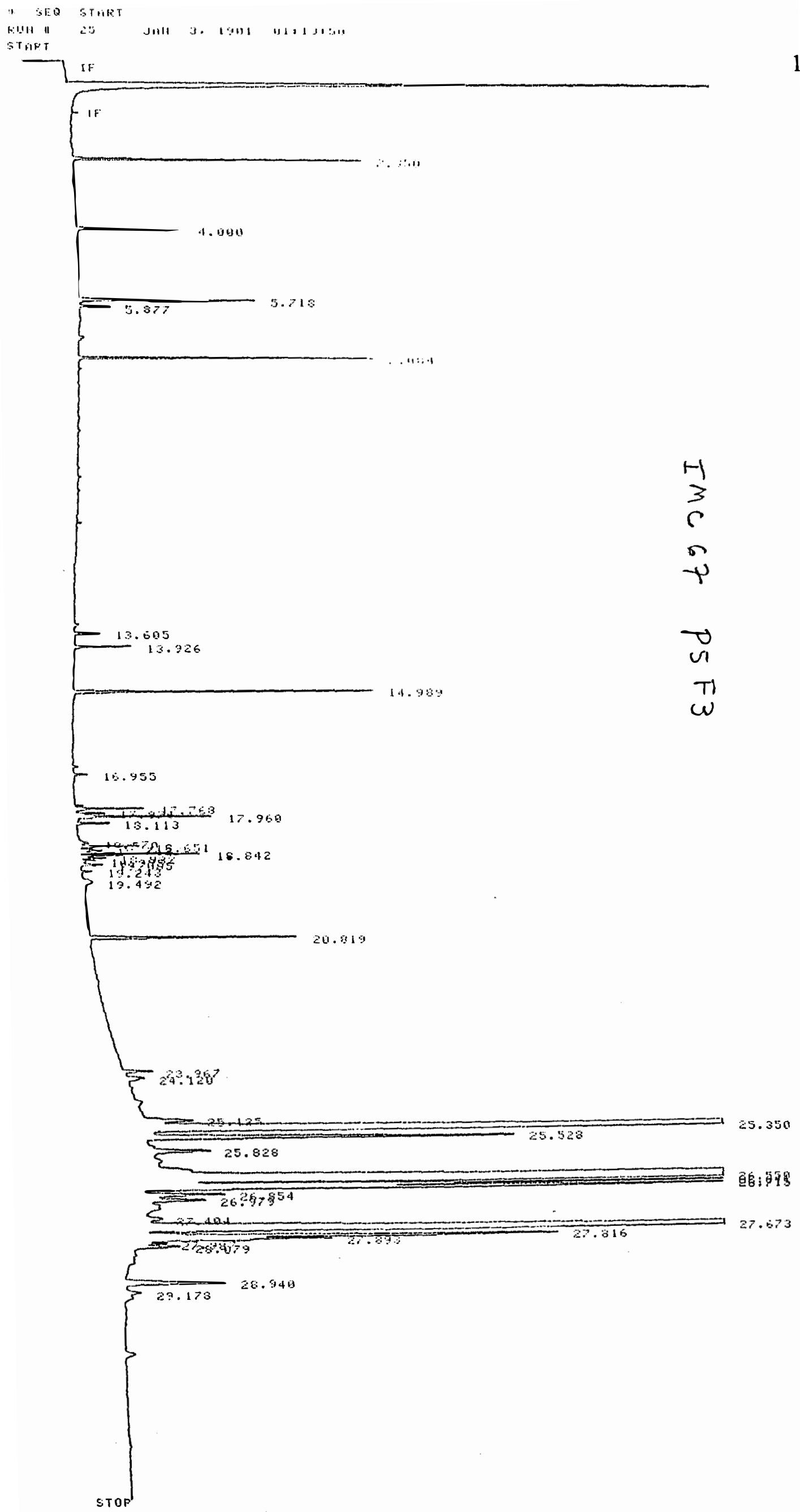




\section{APÊNDICE 3}

Curvas de fusão das manteigas de cacau dos dez genótipos estudados, obtidas pela técnica de Calorimetria Diferencial de Varredura (DSC). Cada termograma corresponde à análise das sementes de um único fruto. 


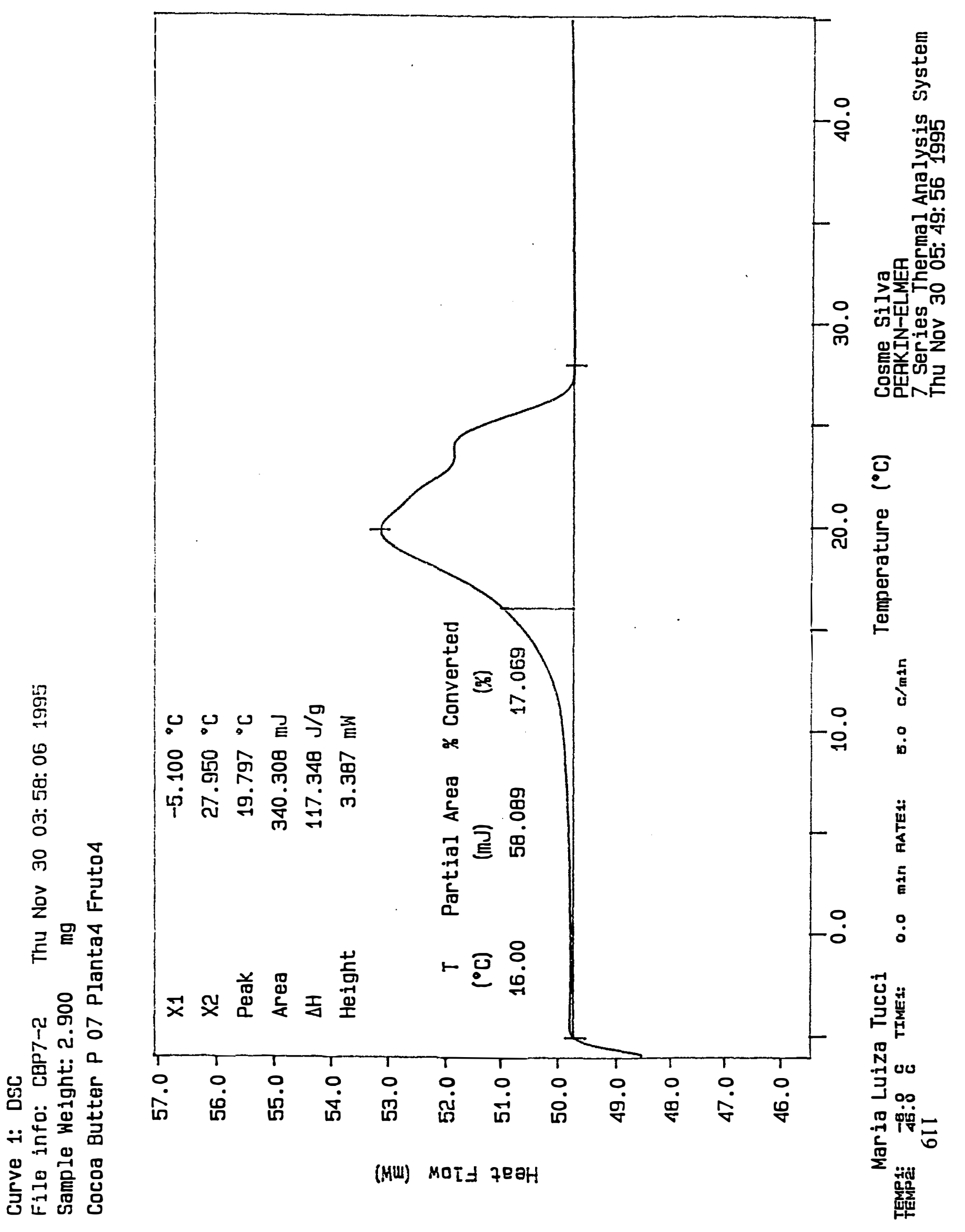




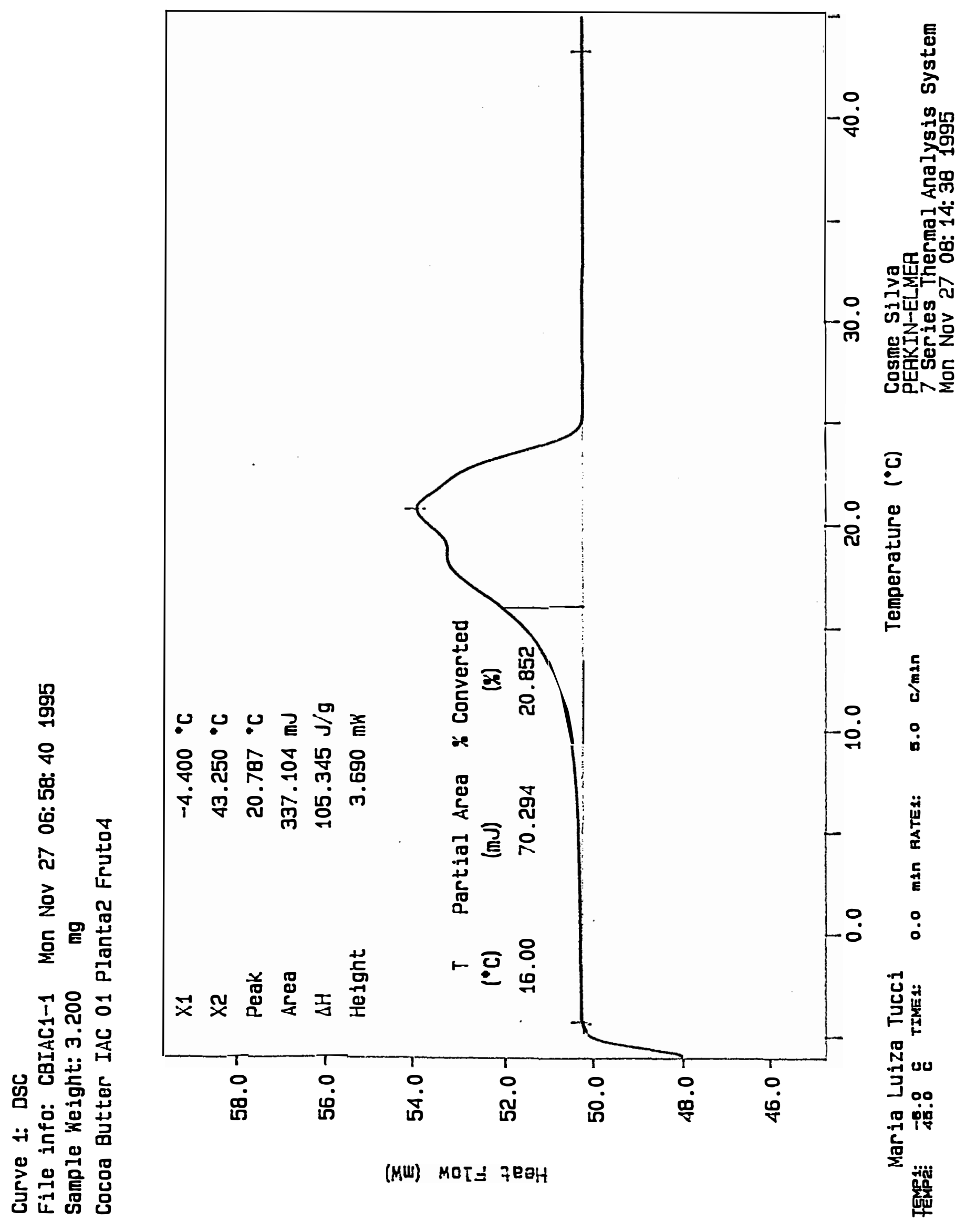




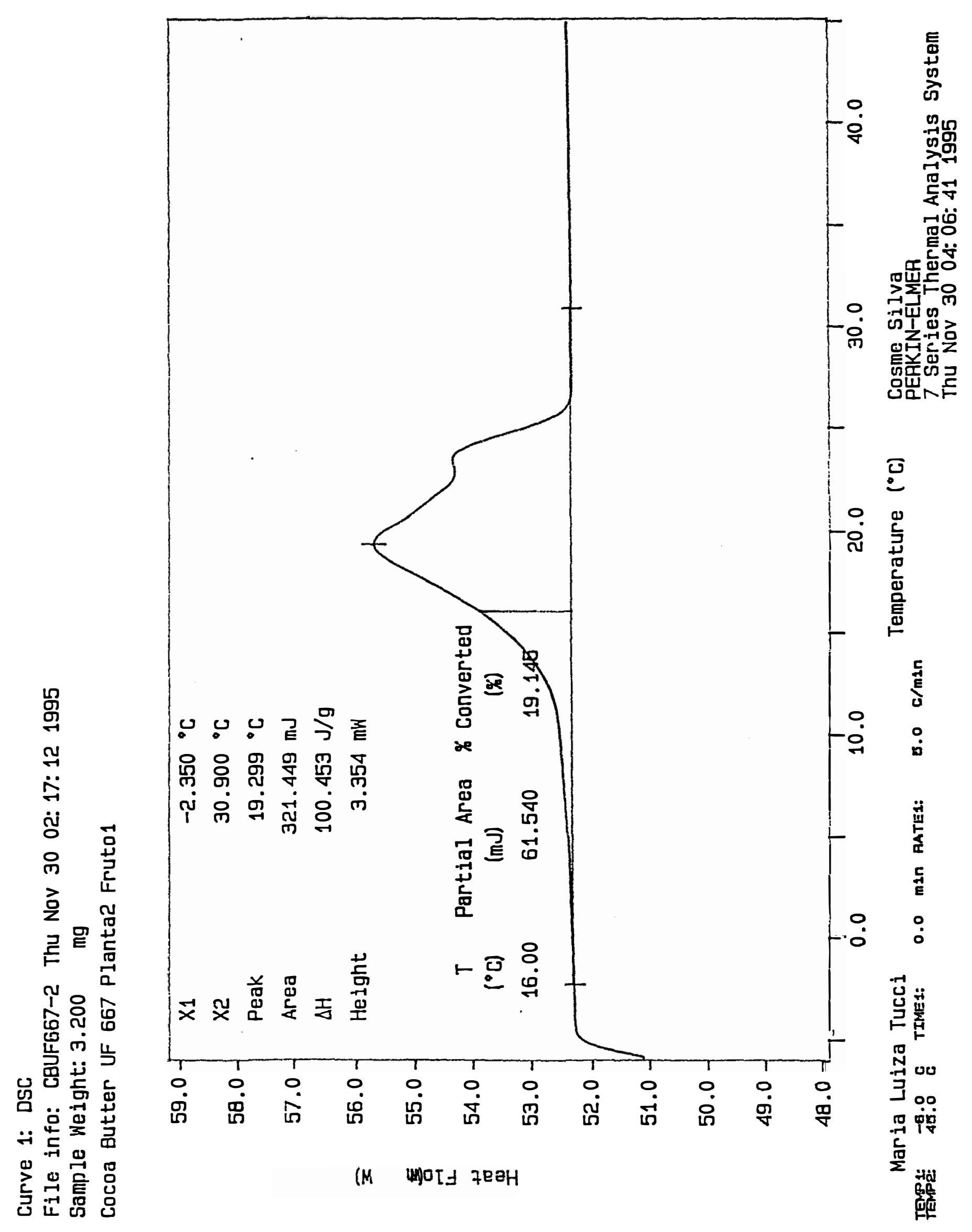




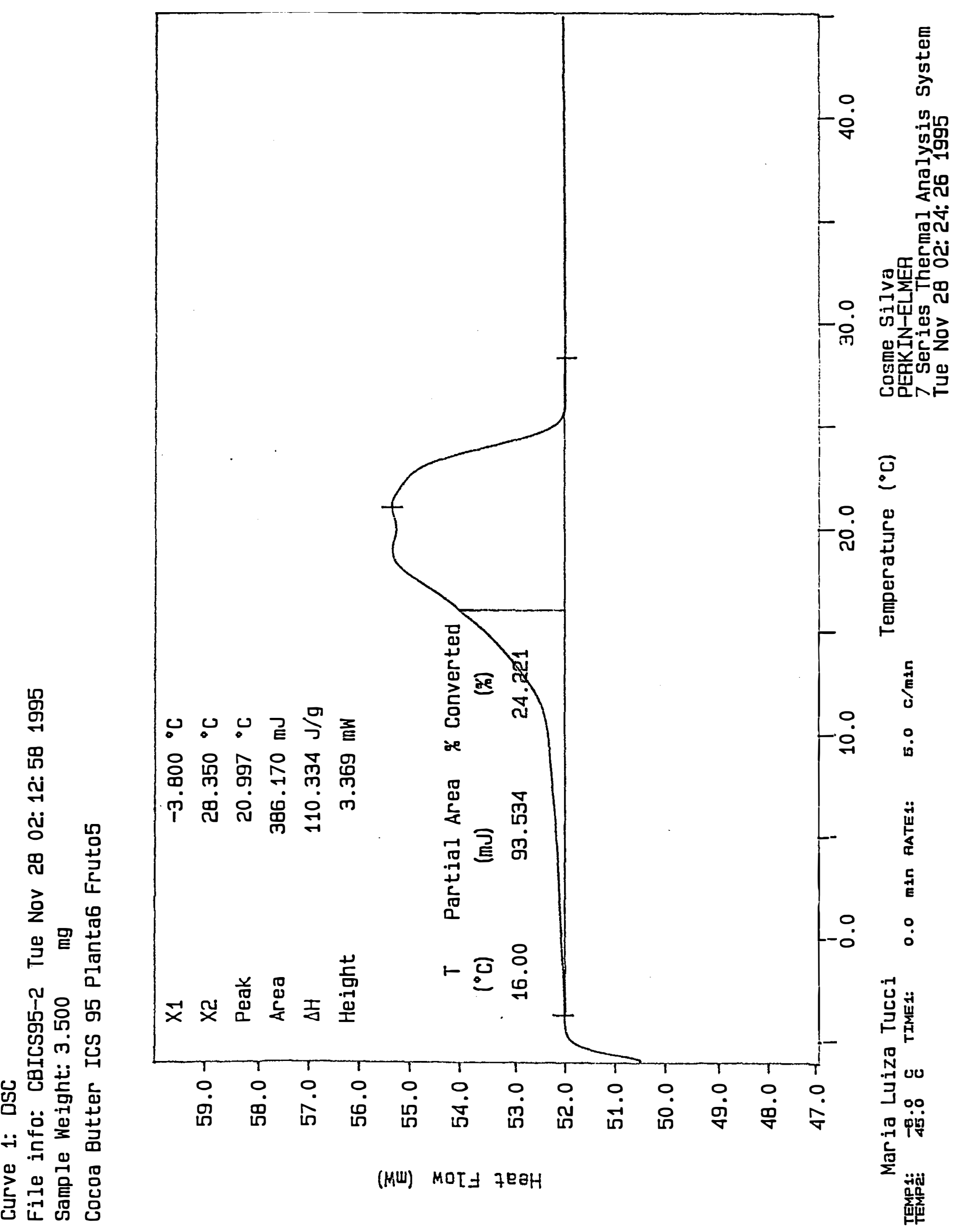




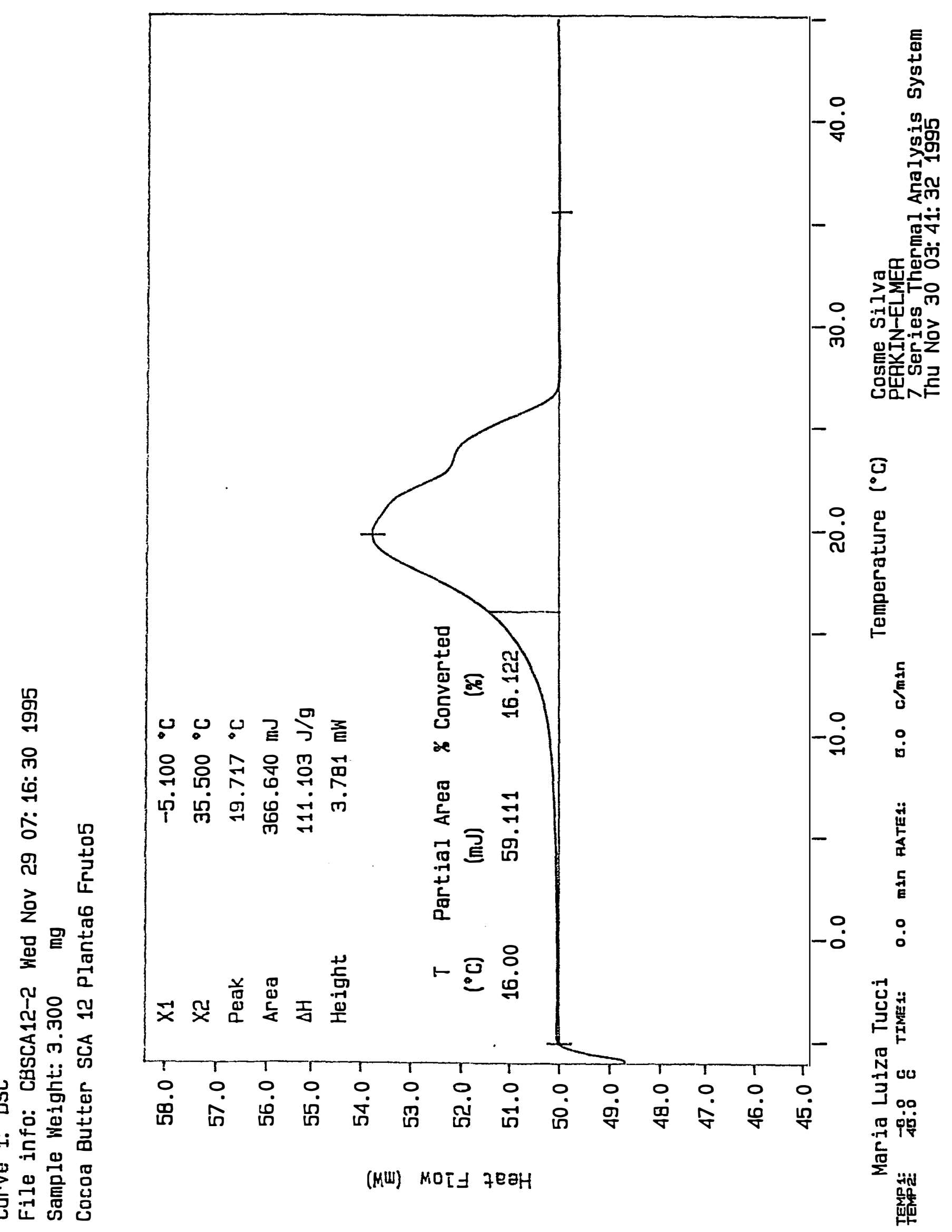




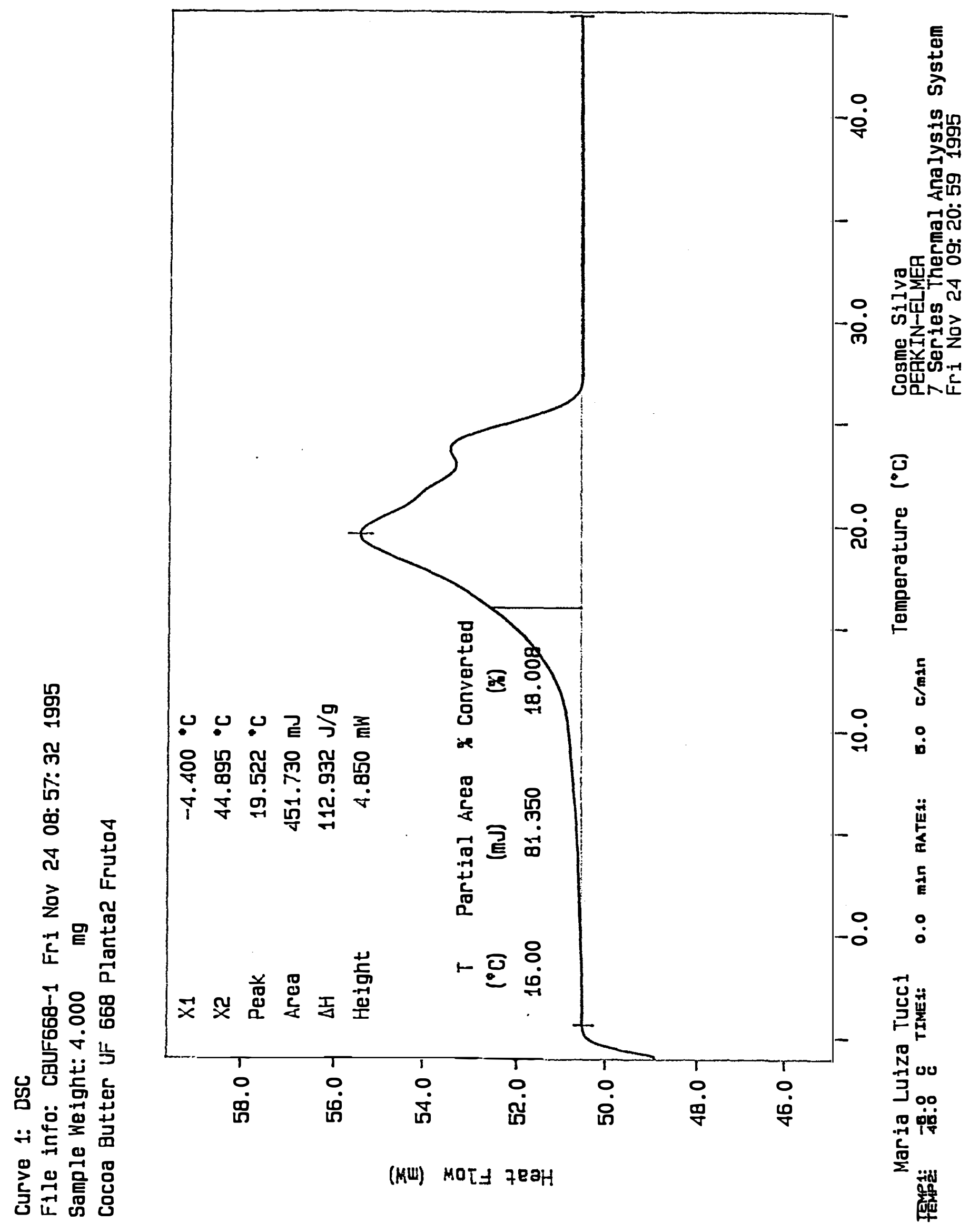




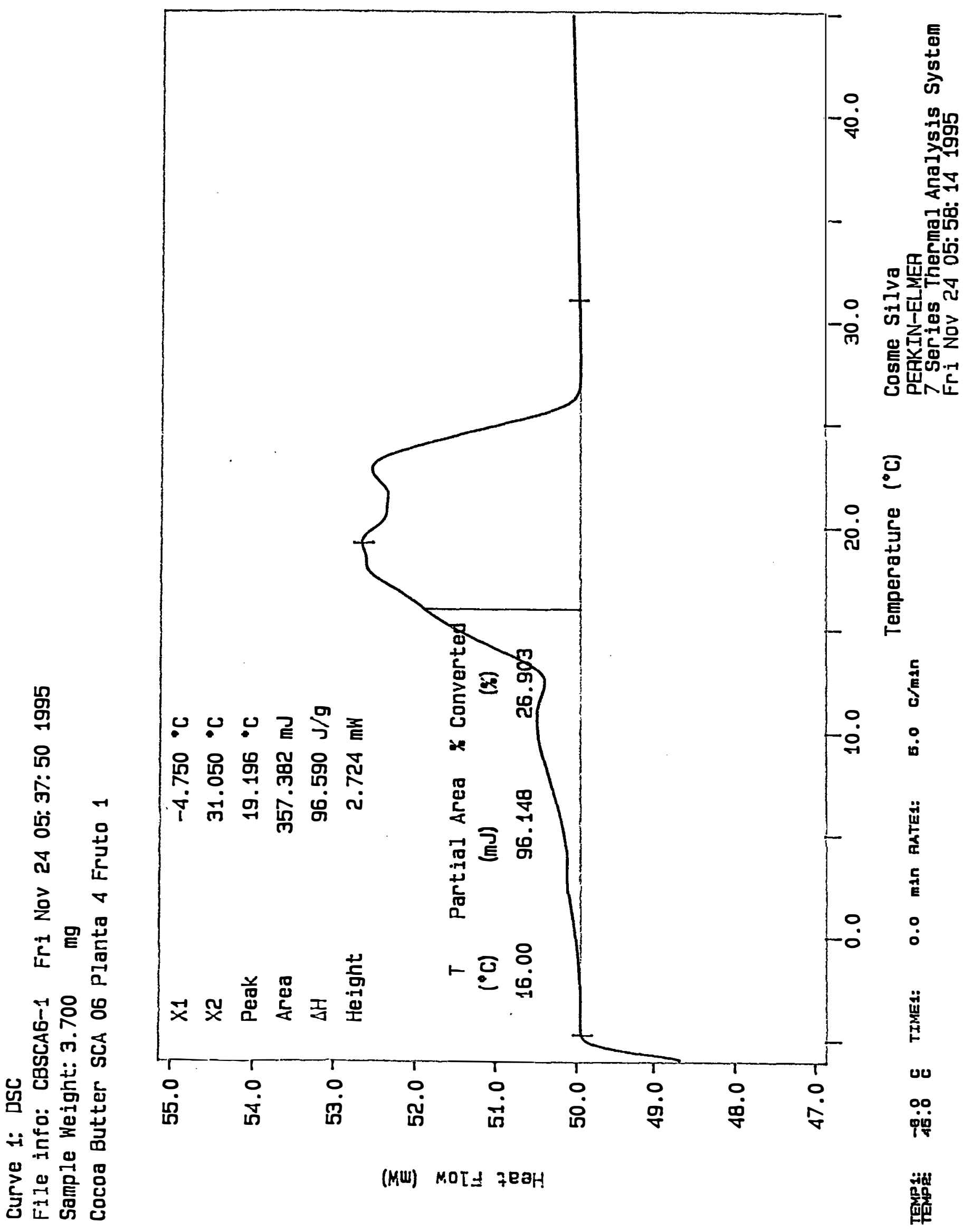




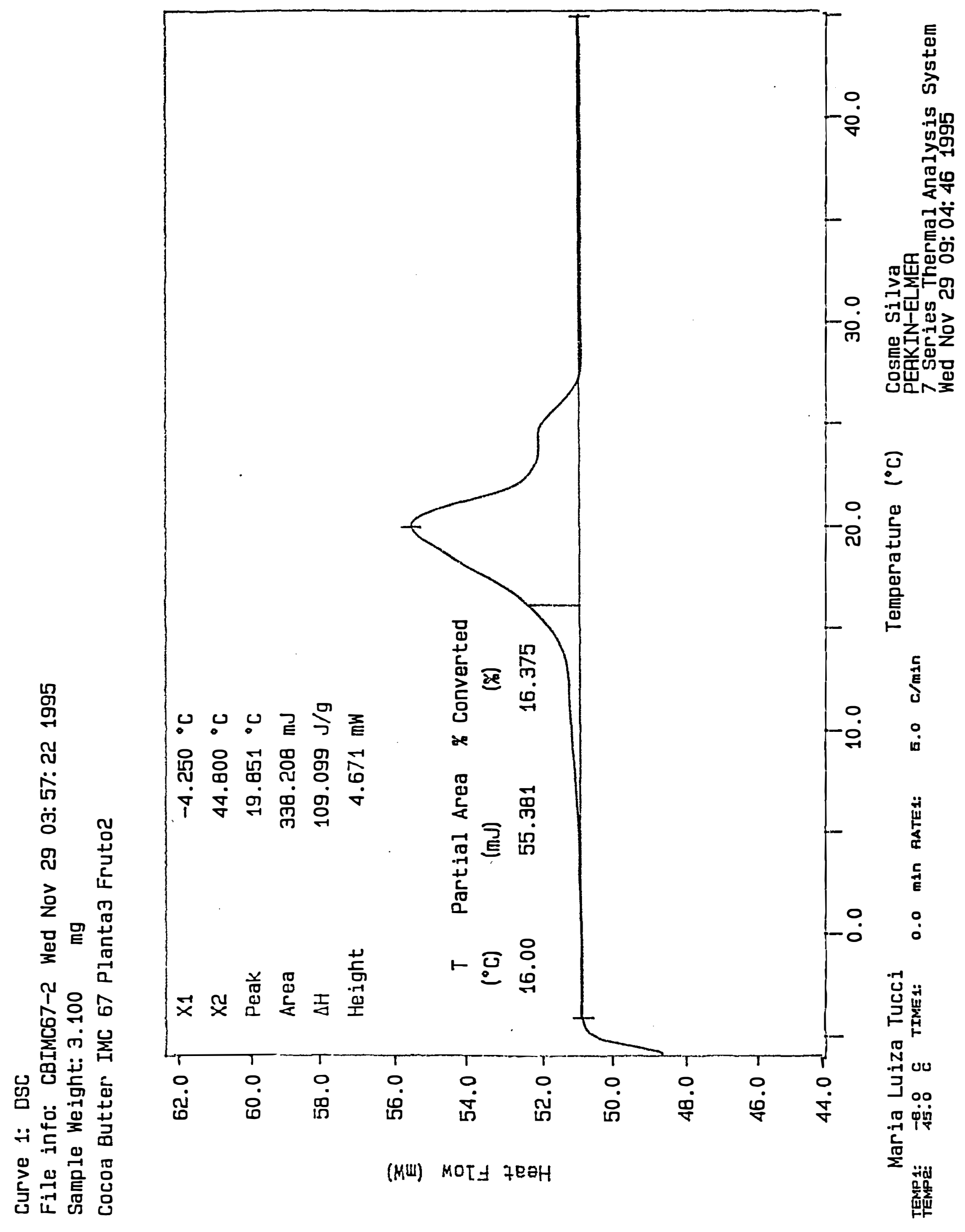




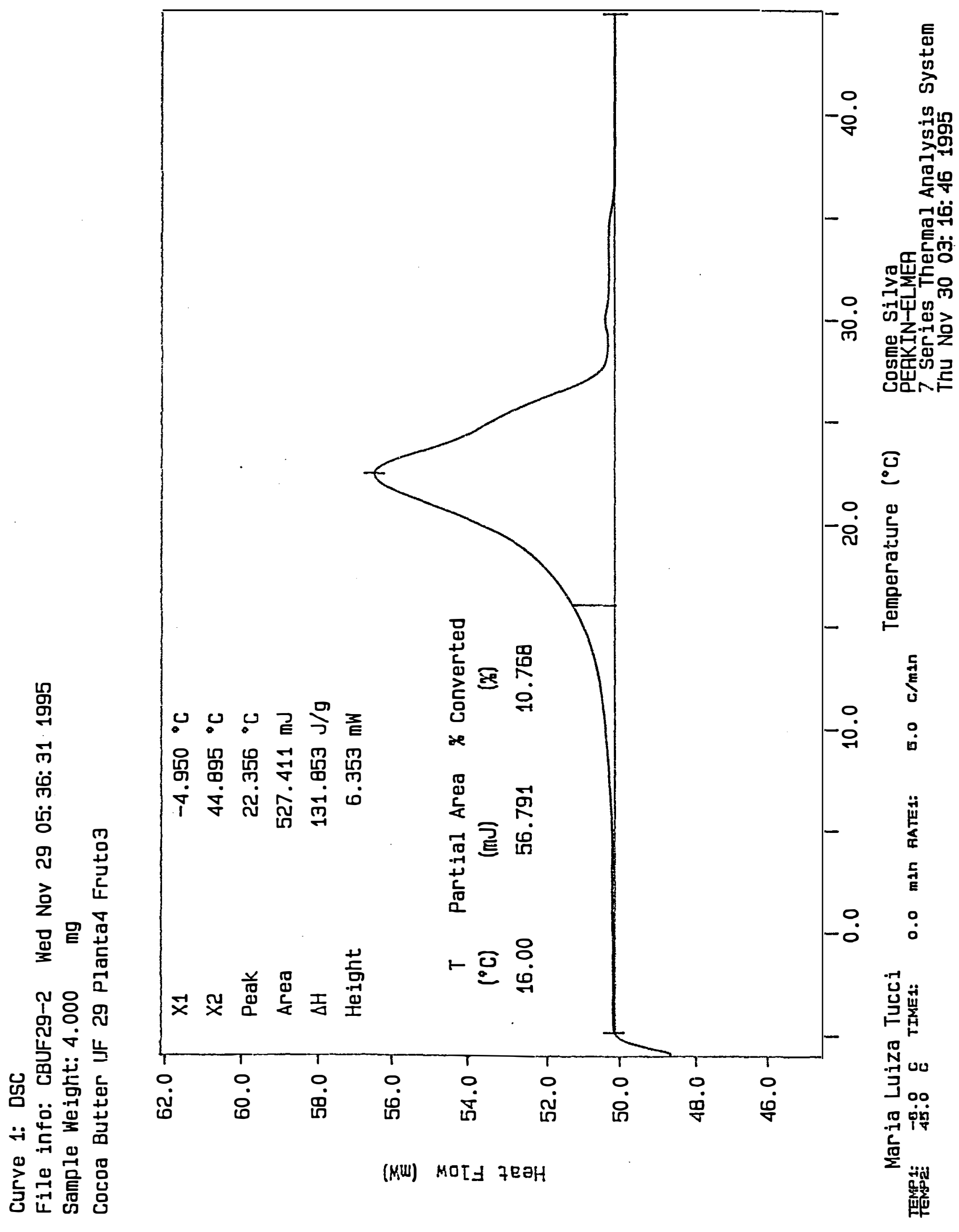




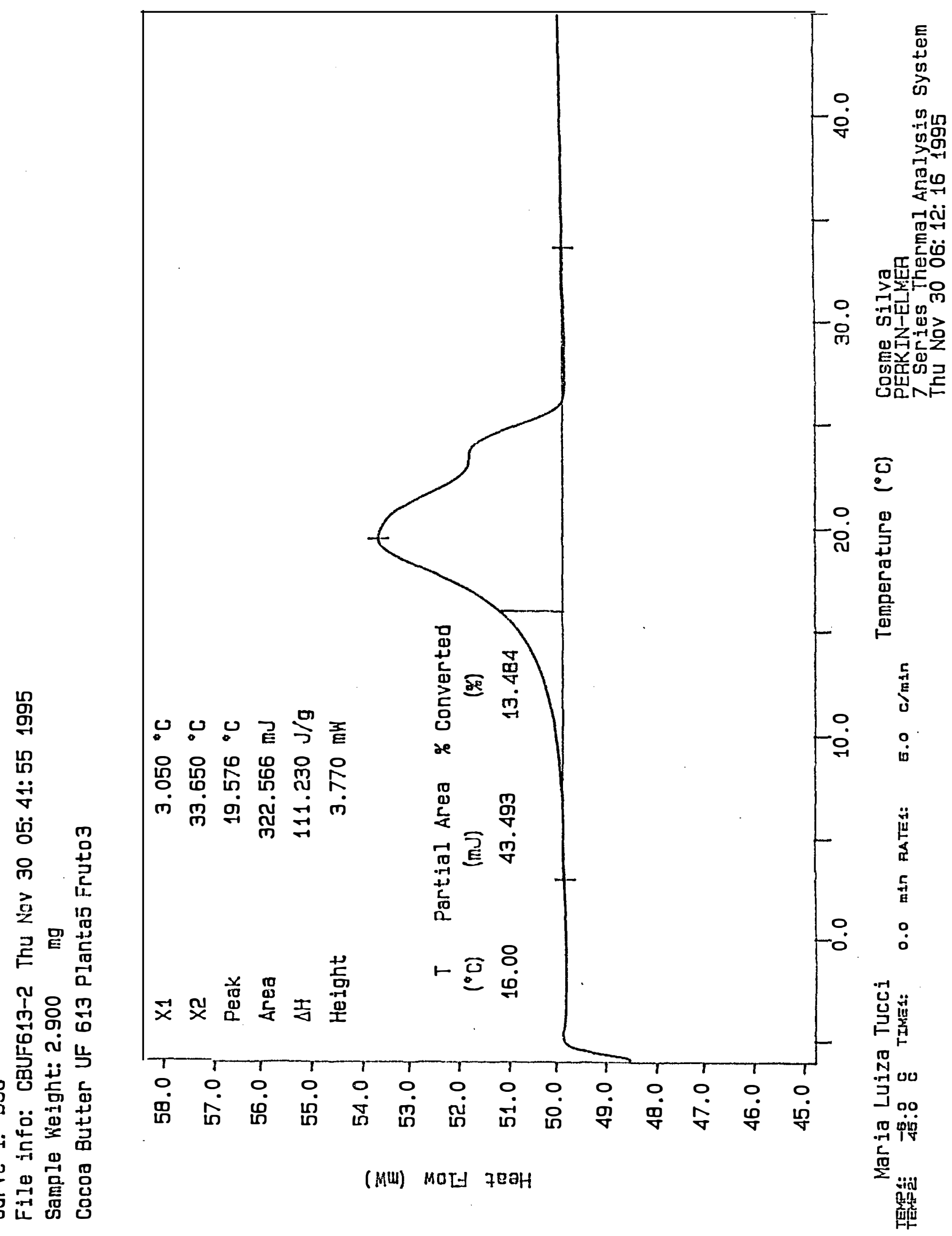

